Prepared in cooperation with Trout Unlimited and the U.S. Forest Service

\title{
The Potential Influence of Changing Climate on the Persistence of Salmonids of the Inland West
}

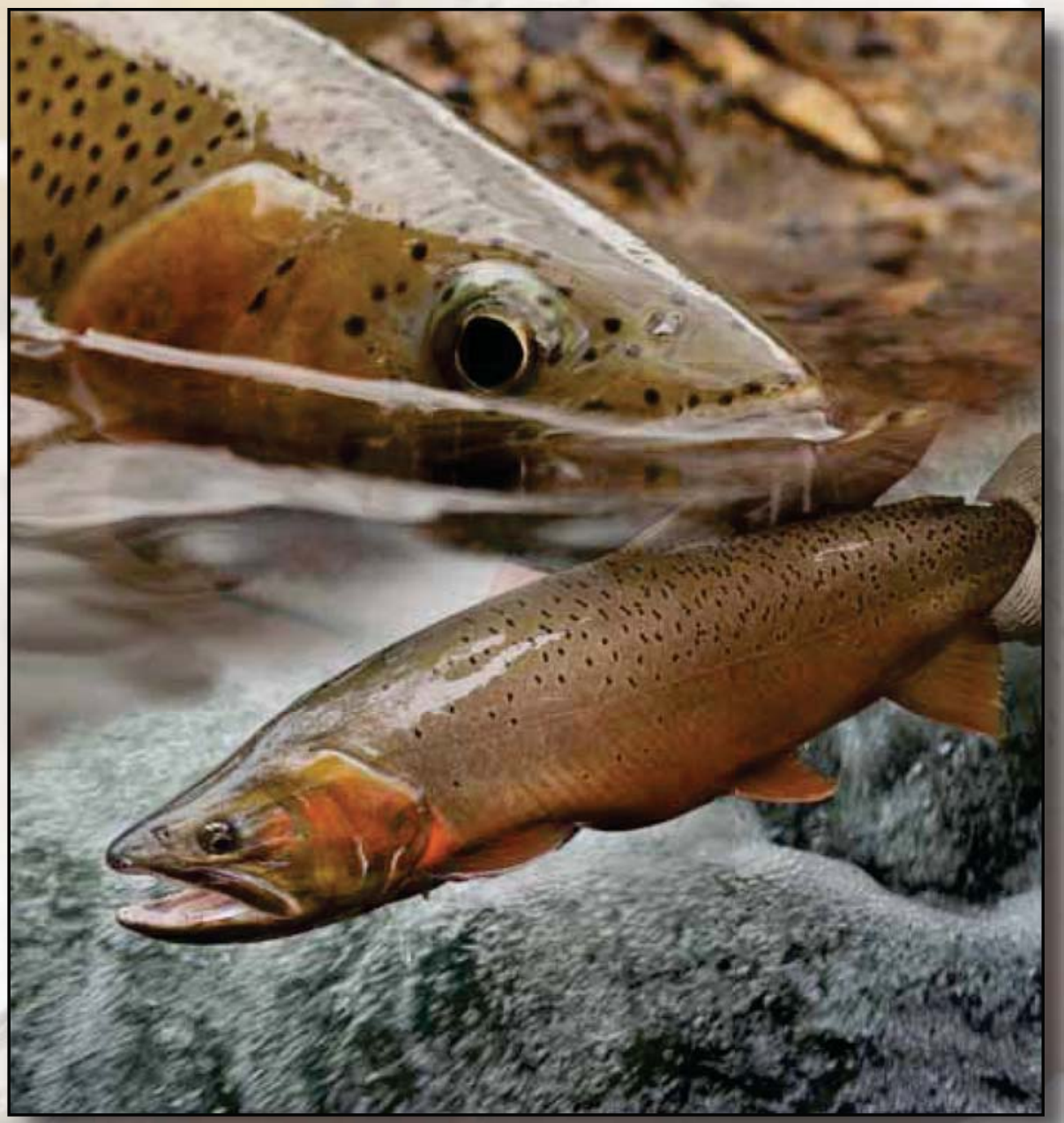

Open-File Report 2010-1236

U.S. Department of the Interior

U.S. Geological Survey 
Cover. Westslope cutthroat trout (top) and Bonneville cutthroat trout (bottom). Photo courtesy of Kirk Dahle and Mike Ebinger. 


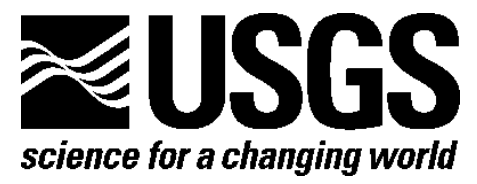

\section{The Potential Influence of Changing Climate on the Persistence of Salmonids of the Inland West}

By A.L. Haak, J.E. Williams, D. Isaak, A. Todd, C.C. Muhlfeld, J.L. Kershner, R.E. Gresswell, S.W. Hostetler, and H.M. Neville

Prepared in cooperation with Trout Unlimited and the U.S. Forest Service

Open-File Report 2010-1236

U.S. Department of the Interior

U.S. Geological Survey 


\section{U.S. Department of the Interior \\ KEN SALAZAR, Secretary}

\section{U.S. Geological Survey \\ Marcia K. McNutt, Director}

U.S. Geological Survey, Reston, Virginia 2010

For product and ordering information:

World Wide Web: http://www.usgs.gov/pubprod

Telephone: 1-888-ASK-USGS

For more information on the USGS-the Federal source for science about the Earth,

its natural and living resources, natural hazards, and the environment:

World Wide Web: http://www.usgs.gov

Telephone: 1-888-ASK-USGS

Suggested citation:

Haak, A.L., Williams, J.E., Isaak, D., Todd, A., Muhlfeld, C., Kershner, J.L., Gresswell, R., Hostetler, S., and Neville, H.M., 2010, The potential influence of changing climate on the persistence of salmonids of the inland west: U.S. Geological Survey Open-File Report 2010-1236, 74 p.

Any use of trade, product, or firm names is for descriptive purposes only and does not imply endorsement by the U.S. Government.

Although this report is in the public domain, permission must be secured from the individual copyright owners to reproduce any copyrighted material contained within this report. 


\section{Contents}

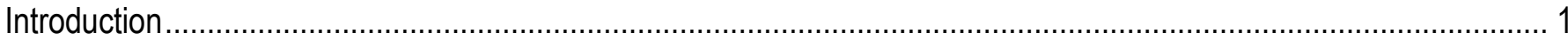

Study Area

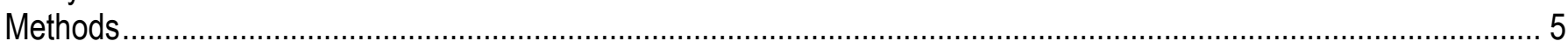

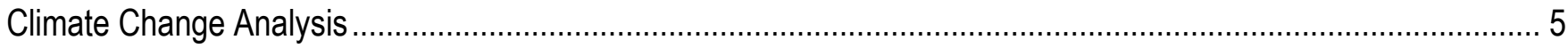

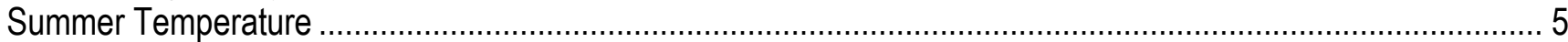

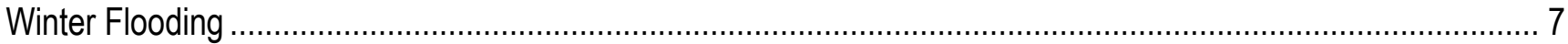

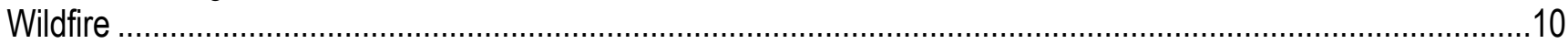

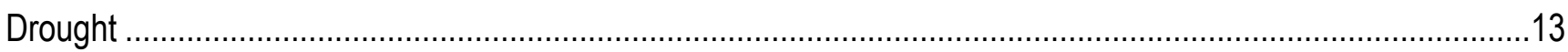

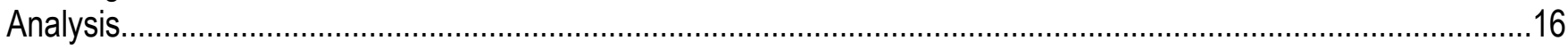

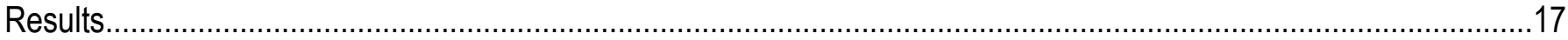

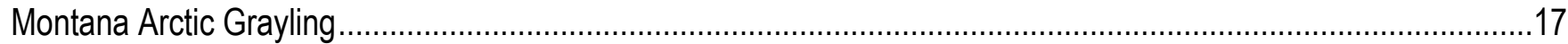

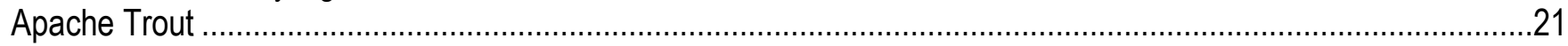

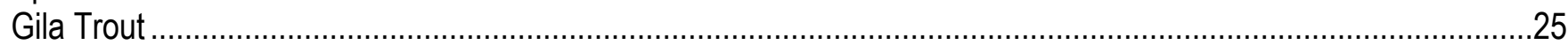

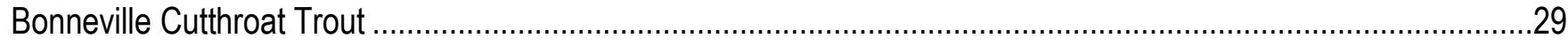

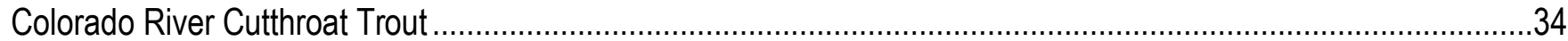

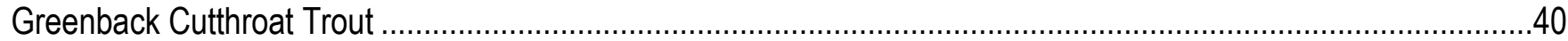

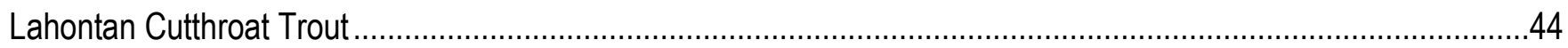

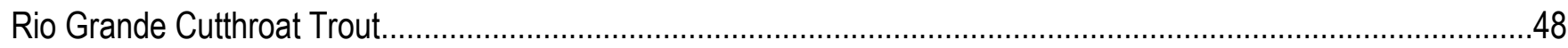

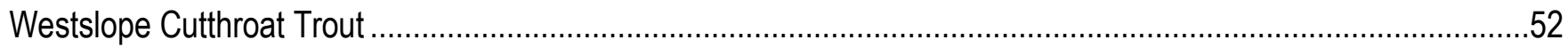

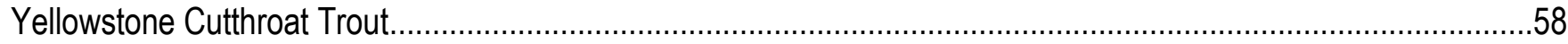

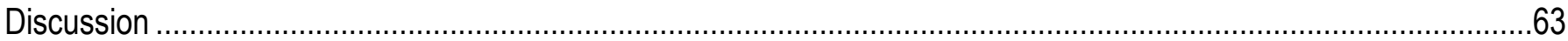

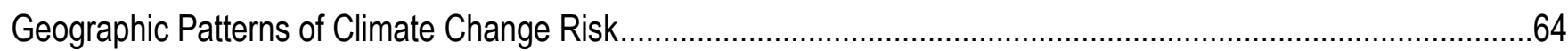

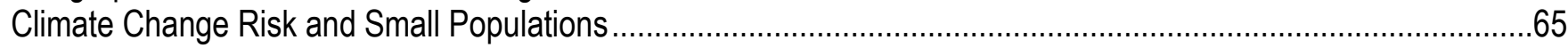

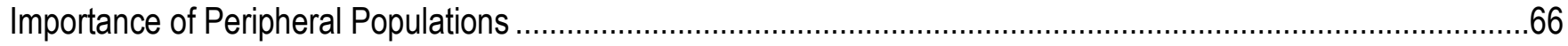

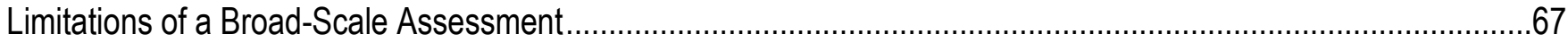

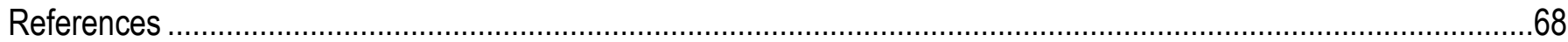

\section{Figures}

1. Geographic scope of project and ranges of native trout and grayling evaluated in the broad-scale assessment.. 4

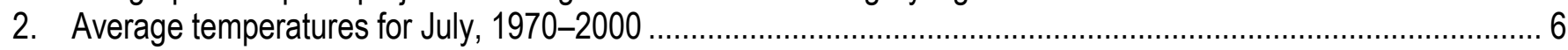

3. Average cumulative precipitation from November 1 to March 30, 1970-2000 …........................................... 8

4. Results of winter flooding analysis ........................................................................................... 9

5. Distribution of the topographic zone of 1,680-2,690 meters defined by Westerling and others (2006) as

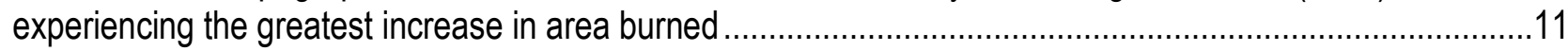

6. Results of LANDFIRE wildfire analysis ..........................................................................................12

7. Projection of Palmer Drought Severity Index (PDSI) by climate division for the period $2035-2060$ by Hoerling

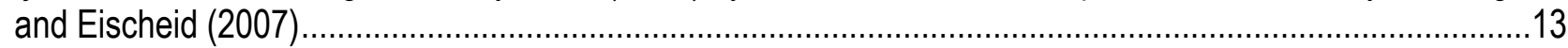

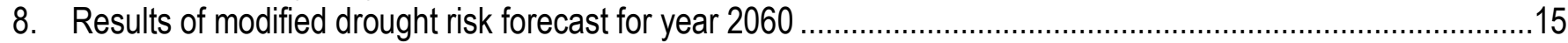

9. Risk of wildfire and winter flooding for Montana Arctic grayling in their current range......................................18

10. Risk of summer temperature increases and drought for Montana Arctic grayling in their current range. .............19

11. Risk of wildfire and winter flooding for Apache trout in their current range. ................................................22

12. Risk of summer temperature increases and drought for Apache trout in their current range ..............................23 
13. Risk of wildfire and winter flooding for Gila trout in their current range. ....................................................26

14. Risk of summer temperature increases and drought for Gila trout in their current range...............................27

15. Risk of wildfire and winter flooding for Bonneville cutthroat trout in their current range ..................................30

16. Risk of summer temperature increases and drought for Bonneville cutthroat trout in their current range ............31

17. Risk of wildfire and winter flooding for Colorado River cutthroat trout in their current range .............................35

18. Risk of summer temperature increases and drought for Colorado River cutthroat trout in their current range ....36

19. Risk of wildfire and winter flooding for Greenback cutthroat trout in their current range ..................................41

20. Risk of summer temperature increases and drought for Greenback cutthroat trout in their current range ...........42

21. Risk of summer temperature increases and drought for Lahontan cutthroat trout in their current range ............45

22. Risk of wildfire and winter flooding for Lahontan cutthroat trout in their current range...................................46

23. Risk of wildfire and winter flooding for Rio Grande cutthroat trout in their current range .................................49

24. Risk of summer temperature increases and drought for Rio Grande cutthroat trout in their current range ..........50

25. Risk of wildfire and winter flooding for Westslope cutthroat trout in their current range ..................................55

26. Risk of summer temperature increases and drought for Westslope cutthroat trout in their current range............56

27. Risk of wildfire and winter flooding for Yellowstone cutthroat trout in their current range ................................59

28. Risk of summer temperature increases and drought for Yellowstone cutthroat trout in their current range .........60

\section{Tables}

1. Temperature thresholds used to characterize suitability by taxon ............................................................ 7

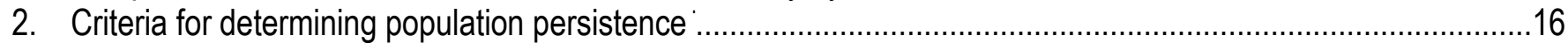

3. Ratings for increased risk from winter flooding, wildfire, drought, and increased summer temperature to subwatersheds and conservation populations of Montana Arctic grayling ...................................................20

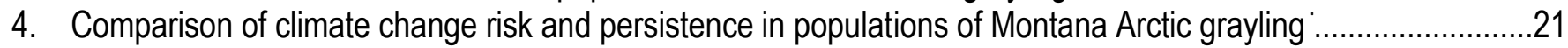

5. Ratings for increased risk from winter flooding, wildfire, drought and increased summer temperature to

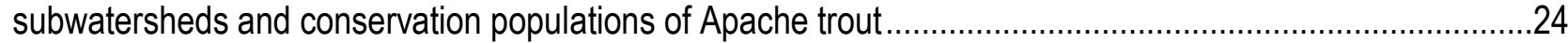

6. Comparison of climate change risk and persistence in populations of Apache trout.......................................25

7. Ratings from increased risk for winter flooding, wildfire, drought, and increased summer temperature for subwatersheds and conservation populations of Gila trout........................................................................28

8. Comparison of climate change risk and persistence in populations of Gila trout.............................................29

9. Ratings for increased risk from winter flooding, wildfire, drought, and increased summer temperature to subwatersheds and conservation populations of Bonneville cutthroat trout..............................................32

10. Comparison of climate change risk and persistence in populations of Bonneville cutthroat trout .......................33

11. Ratings for increased risk from winter flooding, wildfire, drought, and increased summer temperature to subwatersheds and conservation populations of Colorado River cutthroat trout ..........................................37

12. Comparison of climate change risk and persistence in populations of Colorado River cutthroat trout ...............39

13. Ratings for increased risk from winter flooding, wildfire, drought, and increased summer temperature for subwatersheds and conservation populations of Greenback cutthroat trout.............................................43

14. Comparison of climate change risk and persistence in populations of Greenback cutthroat trout......................44

15. Ratings for increased risk from winter flooding, wildfire, drought, and increased summer temperature for subwatersheds and conservation populations of Lahontan cutthroat trout ..................................................47

16. Comparison of climate change risk and persistence in populations of Lahontan cutthroat trout........................48

17. Ratings for increased risk from winter flooding, wildfire, drought, and increased summer temperature for subwatersheds and conservation populations of Rio Grande cutthroat trout............................................51

18. Comparison of climate change risk and persistence in populations of Rio Grande cutthroat trout 1 ....................52

19. Ratings for increased risk from winter flooding, wildfire, drought, and increased summer temperature for subwatersheds and conservation populations of Westslope cutthroat trout

20. Comparison of climate change risk and persistence in populations of Westslope cutthroat trout. 
21. Ratings for increased risk from winter flooding, wildfire, drought, and increased summer temperature for subwatersheds and conservation populations of Yellowstone cutthroat trout..... 61

22. Comparison of climate change risk and persistence in populations of Yellowstone cutthroat trout 


\section{Conversion Factors}

\begin{tabular}{lcl}
\hline \multicolumn{1}{c}{ Multiply } & By & \multicolumn{1}{c}{ To obtain } \\
\hline centimeter $(\mathrm{cm})$ & Length & \\
meter $(\mathrm{m})$ & 0.3937 & inch (in.) \\
kilometer $(\mathrm{km})$ & 3.281 & foot (ft) \\
kilometer $(\mathrm{km})$ & 0.6214 & mile (mi) \\
meter $(\mathrm{m})$ & 0.5400 & mile, nautical (nmi) \\
& 1.094 & yard (yd) \\
\hline hectare (ha) & Area & \\
square kilometer $\left(\mathrm{km}^{2}\right)$ & 2.471 & acre \\
hectare (ha) & 247.1 & acre \\
square kilometer $\left(\mathrm{km}^{2}\right)$ & 0.003861 & square mile $\left(\mathrm{mi}^{2}\right)$ \\
\hline
\end{tabular}

Temperature in degrees Celsius $\left({ }^{\circ} \mathrm{C}\right)$ may be converted to degrees Fahrenheit $\left({ }^{\circ} \mathrm{F}\right)$ as follows:

${ }^{\circ} \mathrm{F}=\left(1.8 \mathrm{x}^{\circ} \mathrm{C}\right)+32$

Temperature in degrees Fahrenheit $\left({ }^{\circ} \mathrm{F}\right)$ may be converted to degrees Celsius $\left({ }^{\circ} \mathrm{C}\right)$ as follows:

${ }^{\circ} \mathrm{C}=\left({ }^{\circ} \mathrm{F}-32\right) / 1.8$ 


\title{
The Potential Influence of Changing Climate on the Persistence of Inland Native Salmonids
}

\author{
By A.L. Haak, ${ }^{1}$ J.E. Williams, ${ }^{2}$ D. Isaak, ${ }^{3}$ A. Todd, ${ }^{4}$ C.C. Muhlfeld,${ }^{5}$ J.L. Kershner, ${ }^{6,7}$ R.E. Gresswell, ${ }^{6}$ S.W. \\ Hostetler, ${ }^{8}$ and H.M. Neville ${ }^{1}$
}

\section{Introduction}

The Earth's climate warmed steadily during the 20th century, and mean annual air temperatures are estimated to have increased by $0.6^{\circ} \mathrm{C}$ (Intergovernmental Panel on Climate Change, 2007). Although many cycles of warming and cooling have occurred in the past, the most recent warming period is unique in its rate and magnitude of change (Siegenthaler and others, 2005) and in its association with anthropogenic emissions of greenhouse gases (Intergovernmental Panel on Climate Change, 2007). The climate in the western United States warmed in concert with the global trend but at an accelerated rate $\left(+0.8^{\circ} \mathrm{C}\right.$ during the 20th century; Saunders and others, 2008). The region could also prove especially sensitive to future changes because the relatively small human population is growing rapidly, as are demands on limited water supplies.

Regional hydrological patterns are dominated by seasonal snow accumulation at upper elevations. Most of the region is relatively dry, and both terrestrial and aquatic ecosystems are strongly constrained by water availability (Barnett and others, 2008; Brown and others, 2008). Stream environments are dynamic and climatically extreme, and salmonid fishes are the dominant elements of the native biodiversity (McPhail and Lindsey, 1986; Waples and others, 2008). Salmonids have broad economic and ecologic importance, but a century of intensive water resource development, nonnative fish stocking, and land use has significantly reduced many populations and several taxa are now protected under the Endangered Species Act (Thurow and others, 1997; Trotter, 2008). Because salmonids require relatively pristine, cold water environments and are often isolated in headwater habitats, members of this group may be especially vulnerable to the effects of a warming climate (Keleher and Rahel, 1996; Rieman and others, 2007; Williams and others, 2009).

Warming during the 20th century drove a series of environmental trends that have profound implications for many aspects of salmonid habitat, including disturbance regimes such as wildfire, and unfavorable changes to thermal and hydrologic properties of aquatic systems. Warmer air temperatures have been associated with decreased winter snow accumulations, have accelerated snowmelt, and have

\footnotetext{
${ }^{1}$ Trout Unlimited, 910 West Main Street, Suite 342, Boise, Idaho 83702, USA

${ }^{2}$ Trout Unlimited, 329 Crater Lake Avenue, Medford, Oregon 97504, USA

${ }^{3}$ U.S. Forest Service, Rocky Mountain Research Station, Boise Aquatic Sciences Laboratory, 322 E. Front Street, Suite 401, Boise, Idaho 83702 USA

${ }^{4}$ U.S. Geological Survey, Crustal Imaging and Characterization Team, Denver, Colorado 80225

${ }^{5}$ U.S. Geological Survey, Northern Rocky Mountain Science Center, Glacier Field Office, Glacier National Park, West Glacier, Montana 59936, USA

${ }^{6}$ U.S. Geological Survey, Northern Rocky Mountain Science Center, 2327 University Way, Suite 2, Bozeman, Montana 59715

${ }^{7}$ Primary point of contact

${ }^{8}$ U.S. Geological Survey, Department of Geosciences, Oregon State University Corvallis, Oregon 97331
} 


\section{2 | Introduction}

advanced the timing of peak runoff by several days to weeks across most of western North America (Stewart and others, 2005; Barnett and others, 2008). Less snow and earlier runoff decrease aquifer recharge, make less water available for groundwater inputs to streams, and are contributing to widespread decreases in summer low flows (Stewart and others, 2005; Rood and others, 2008; Luce and Holden 2009). Interannual variability in stream flow is increasing, as is the persistence of multi-year extreme conditions (McCabe and others, 2004; Pagano and Garen 2005). In many areas of western North America, flood risks have increased in association with warmer temperatures during the 20th century (Hamlet and Lettenmaier, 2005). Streams where midwinter temperatures are near freezing have proven especially sensitive to increased flooding because of associated transitional hydrological patterns (mixtures of rainfall and snowmelt) and propensity for occasional rain-on-snow events to rapidly melt winter snowpack and generate large floods (Hamlet and Lettenmaier, 2005).

Stream temperatures in many areas are increasing (Peterson and Kitchell, 2001; Morrison and others, 2002; Bartholow, 2005; Kaushal and others, 2010), due to both air temperature increases and reduced summer flows that make streams more sensitive to warmer air temperatures (Isaak and others, 2010). In recent decades, wildfires have become more common across much of the western United States during periods of more frequent droughts (Westerling and others, 2006; Hoerling and Eischeid, 2007), and local stream temperature can increase in postfire environments (Gresswell, 1999; Dunham and others, 2007). Fire-related temperature increase within streams is commonly a transient phenomenon, lasting only until riparian vegetation has recovered (Gresswell, 1999); however, ongoing climate change could preclude recovery to higher stature, prefire vegetation types in some areas (McKenzie and others, 2004; van Mantgem and Stephenson, 2007), resulting in a loss of critical riparian shading. Additionally, when wildfires occur in steep mountain topographies, the vegetation that stabilizes soils on hillslopes is often killed and landslides become more prevalent (Gresswell, 1999). Landslides into stream channels form debris flows composed of sediment slurries and dead trees that can scour channels to bedrock and further exacerbate stream heating, delay recovery of riparian areas, or extirpate fish populations (Gresswell, 1999; May and Gresswell, 2003; Dunham and others, 2007).

Changes in stream environments will shift habitat distributions, sometimes unpredictably, in both time and space for many salmonid fishes. Water temperature fundamentally influences aquatic ecosystem health because distribution, reproduction, fitness, and survival of ectothermic organisms are inextricably linked to the thermal regime of the environment. Historically, research has focused on defining lethal thermal limits of salmonids (Eaton and others, 1995; Selong and others, 2001; Todd and others, 2008); however, water temperature is known to be important in biological processes at a variety of spatial scales and levels of biological organization (Rahel and Olden, 2008; McCullough and others, 2009). For instance, trout are affected directly by water temperature through feeding, metabolism, and growth rates, and indirectly by factors such as prey availability and species interactions (Wehrly and others, 2007; Rahel and Olden, 2008). Where cold water temperatures currently limit habitat suitability and distributions of some species (for example, at the highest and most northerly distributional extents; Nakano and others, 1996; Coleman and Fausch, 2007), a warming climate may gradually increase the quality and extent of suitable habitat. Over time, previously constrained populations are expected to expand into these new habitats and increase in number. Some evidence suggests this may already be happening in Alaska, where streams in recently deglaciated areas are being colonized by emigrants from nearby salmon and char populations (Milner and others, 2000).

Unfortunately, many of the sensitive salmonid species that are often the focus of western managers are unlikely to benefit from future water temperature increases. Warmer stream temperatures will facilitate invasion by nonnative species that are broadly established in downstream areas into upstream areas where they will compete with native species (Rieman and others, 2006; Rahel and 


\section{The Potential Influence of Changing Climate on the Persistence of Salmonids of the Inland West $\mathbf{3}$}

Olden, 2008; Fausch and others, 2009). In other cases, warmer stream temperatures will render thermally suitable habitats unsuitable in downstream areas and effect net losses of habitat because upstream distributions are often constrained by streams that are too small or steep (Hari and others, 2006; Isaak and others, 2010). Both scenarios are realistic for fish species like bull trout (Salvelinus confluentus) (Rieman and others, 2006; Rieman and others, 2007), the various subspecies of cutthroat trout (Oncorhynchus clarkii) (Williams and others, 2009), Gila trout (Oncorhynchus gilae gilae) (Kennedy and others, 2008), and Apache trout (Oncorhynchus gilae apache) (Rinne and Minckley, 1985; Carmichael and others, 1993). As native species are increasingly confined to smaller and more isolated habitats by a gradually warming climate, the effects of wildfires (whether related to lethal changes in water quality during a fire, channel debris flows, or chronic postfire warming) could have greater proportional effects on remaining habitats (for example, Brown and others, 2001; Rieman and others, 2007). If these changes were accompanied by additional hydrologic alterations associated with changes to the magnitude, frequency, duration, timing, and rate of change of discharge patterns (Jager and others, 1999; Henderson and others, 2000), populations may begin to lose some of their historic resilience and become ever more susceptible to local extirpations.

As dramatic and extensive as climatic and environmental trends are for salmonid habitats, global climate models (GCMs) project that many of these trends will continue and even accelerate until at least the middle of the 21st century (Intergovernmental Panel on Climate Change, 2007). Current projections suggest mean annual air temperatures will increase by an additional $1-3^{\circ} \mathrm{C}$, and early indications are that climate trajectory is at the higher end of this range (Pittock, 2006; Raupach and others, 2007). Although predicted changes vary considerably, even the most conservative estimates suggest a warming rate that will be twice that observed during the 20th century. Projections for the midcentury are most certainly due to the effects of greenhouse gases already emitted or predicted in the short term, uncertainties of the effects of longer-term greenhouse gas emissions, short-term climate cycles, and process errors associated with climate models (Cox and Stephenson, 2007). Projections of changes in total precipitation are less certain than those for air temperatures, but most GCMs project relatively small changes in the Northwest, with the exception of slightly drier summer periods (Mote and others, 2008; Karl and others, 2009). In the Southwest, however, significant decreases (such as 15-30 percent) are projected during most periods of the year, and this area is one of the few for which Intergovernmental Panel on Climate Change (2007) precipitation projections have a high level of certainty (Hoerling and Eischeid, 2007; Karl and others, 2009). Clearly, managers of native salmonids in the western United States should consider adjusting management strategies to accommodate a warmer and possibly drier future (Williams and others, 2009). Tools are needed to forecast where important changes may occur and how conservation efforts should be prioritized. In this Open-File Report, we document our initial efforts in this regard for 10 species and subspecies of inland trout and Montana Arctic grayling (Thymallus arcticus) across the western United States.

\section{Study Area}

Our study examined the influence of changing climate on the persistence of native trout and grayling within 11 western States (fig. 1). The study area ranged from the crests of the Cascades and Sierra Nevada eastward through the Rocky Mountains, Great Basin, and Southwest Deserts within the western United States. The focal taxa were westslope cutthroat trout (Oncorhynchus clarkii lewisi), Yellowstone cutthroat trout $(O$. clarkii bouvieri), Lahontan cutthroat trout $(O$. clarkii henshawi), Bonneville cutthroat trout (O. clarkii utah), Colorado River cutthroat trout (O. clarkii pleuriticus), greenback cutthroat trout (O. clarkii stomias), Rio Grande cutthroat trout (O. clarkii virginalis), Apache trout (O. gilae apache), Gila trout (O. gilae gilae), and Montana Arctic grayling (Thymallus arcticus). 


\section{$4 \mid$ Study Area}

We defined the spatial extent for historic and current distributions based on the most recent range-wide assessments for Bonneville cutthroat trout (May and Albeke, 2005), Colorado River cutthroat trout (Hirsch and others, 2006), westslope cutthroat trout (Shepard and others, 2003), Rio Grande cutthroat trout (Alves and others, 2007), and Yellowstone cutthroat trout (May and others, 2007). When a rangewide assessment was not available, we relied on information obtained from published recovery plans or on the opinion of local experts, including the following unpublished data: Apache trout, U.S. Fish and Wildlife Service and Arizona Game and Fish Department (2007); greenback cutthroat trout, U.S. Fish and Wildlife Service (1998); Lahontan cutthroat trout, U.S. Fish and Wildlife Service (5-Year Status Review 2009); Gila trout, New Mexico Department of Game and Fish and U.S. Fish and Wildife Service (2009); and Montana Arctic grayling, Montana Fish Wildlife and Parks (C.M. Kaya, 1992) (historic extent) and Montana Fish Wildlife and Parks (2008) (current extent).

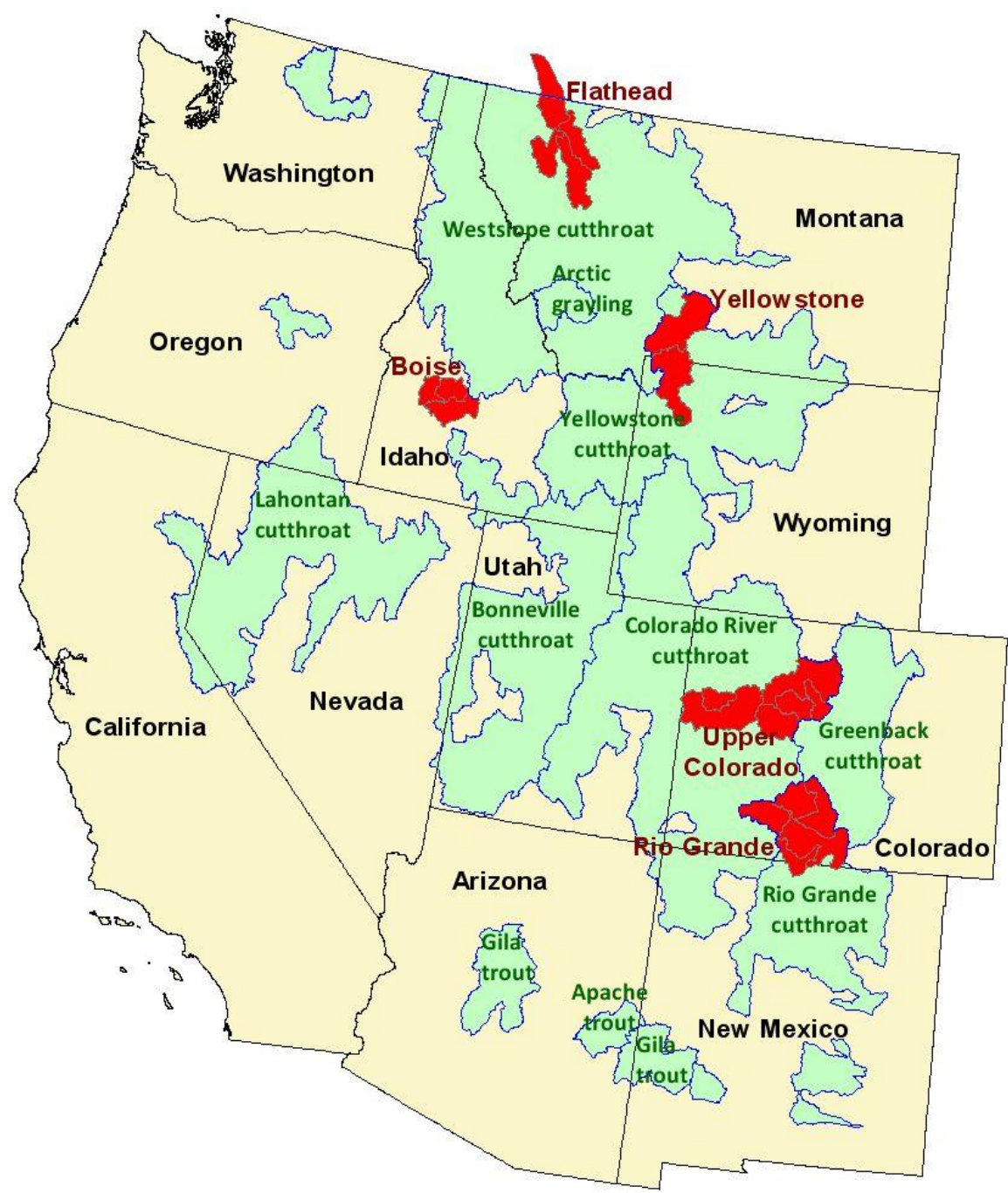

Figure 1. Geographic scope of project and ranges of native trout and grayling evaluated in the broad-scale assessment. Areas in green represent the historic distribution of the selected subspecies, while areas in red represent more detailed analyses in selected areas based on the availability of data. 


\section{The Potential Influence of Changing Climate on the Persistence of Salmonids of the Inland West $\mathbf{5}$}

\section{Methods}

Our assessment of the effects of climate change on the persistence of western native trout is based on a coarse filter evaluation of four environmental factors potentially driven by climate change and a detailed assessment of current habitat fragmentation across the historic ranges of 10 species and subspecies of trout and the Montana Arctic grayling. We used a $3^{\circ} \mathrm{C}$ increase in air temperature, which is consistent with higher end GCM projections for the western United States by 2050 (Climate Impacts Group, 2004), to determine the risk to trout populations from each of these four factors: (1) increased summer temperature, (2) increased winter flooding, (3) increased wildfire risk, and (4) protracted drought. The results were summarized for each factor by subwatershed (HUC 6, 6th field of the hydrologic unit code) across the extent of the historic distribution for each taxon. We then analyzed the likelihood of population persistence (under current conditions) based on information drawn from the literature on relationships between persistence and fish abundance, habitat connectivity and patch size

for each taxon. The results of this analysis were combined with the results of the coarse filter evaluation to provide a spatially explicit characterization of extirpation risk to native trout populations.

\section{Climate Change Analysis}

The coarse filter evaluation of our four environmental factors driven by climate change was conducted in a geographic information system (GIS) environment. Analytical processes used a spatially distributed model across the eleven western States. The final risk scores were aggregated by subwatershed to determine an area-weighted average score for each subwatershed within the historic and current ranges of each taxon. More details are provided by Williams and others (2009).

\section{Summer Temperature}

Coldwater fish are highly sensitive to water temperature. The paucity of organized water temperature databases at a regional scale and the strong correlation between air and water temperature make air temperature a reasonable surrogate for analyzing thermal changes in aquatic environments across the study area. Our analysis applies the methods of Rahel and others (1996), who used changes in mean July air temperature, often the hottest month of the year in the Rocky Mountains, to model habitat loss due to global warming for a coldwater guild of brown, rainbow, brook, and cutthroat trout in the Rocky Mountains.

We used data on the national average air temperature for July from 1970 to 2000 (800-m spatial resolution) published by Daly and others (2008) to establish a baseline from which to model climate change (fig. 2). The average July temperature was used to characterize the thermal limits for each species or subspecies based on the relationship between the historical distribution and air temperature, assuming that this relationship would reflect species-specific adaptations and preferences. By using historic rather than current distributions to define thermal limits, we hoped to minimize anthropogenic effects on species distribution and emphasize fish responses to natural environmental conditions. Stream length (kilometers $[\mathrm{km}]$ ) of historic habitat was calculated for $1^{\circ} \mathrm{C}$ temperature intervals for each taxon and displayed graphically to define three thermal classes for each taxon: suitable, marginal, and unsuitable. Most taxa exhibited a normal distribution in 85-90 percent of the historically occupied habitat associated with temperatures less than one standard deviation above the mean. Obvious breakpoints on the graph that bracketed the first standard deviation above the mean defined the thresholds for marginal and unsuitable thermal classes (table 1). An effort was made to maintain similar percentages between species of historic habitat in each class. Of the historic habitat, 85-90 percent was classified as thermally suitable and typically less than 5 percent was considered thermally unsuitable. 


\section{6 | Methods}

The remaining habitat was classified as thermally marginal and included those places where local conditions (for example, riparian shading, channel depth, and flow) could make the difference between suitable and unsuitable conditions. This category applied to about 10-15 percent of the historic distribution for each taxon. Temperature thresholds were used to characterize habitat suitability by taxon (table 1).

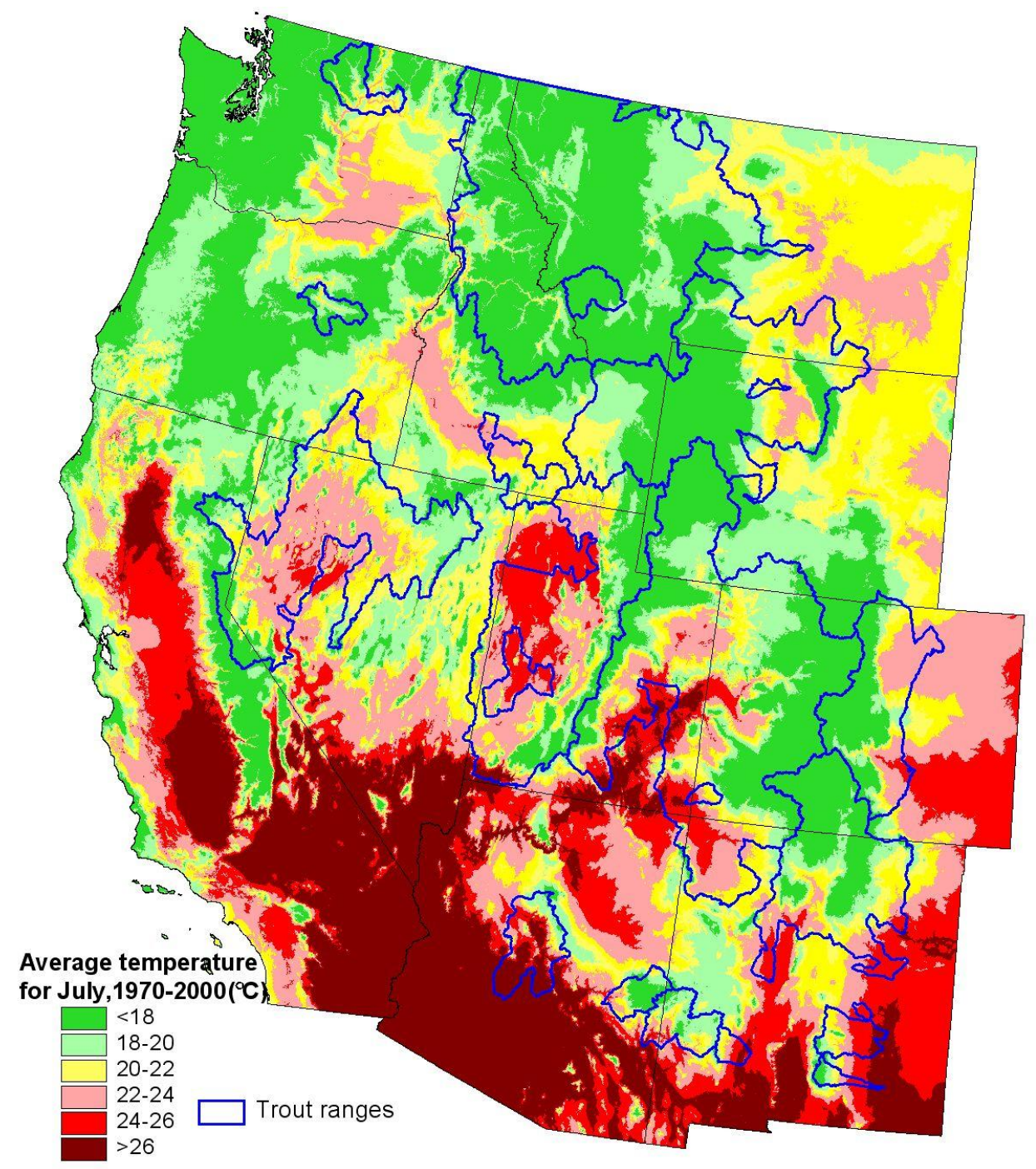

Figure 2. Average temperatures for July, 1970-2000 (Daly and others (2008). Temperature measurements within native trout ranges (blue lines) show the variation in thermal conditions between the southwestern and northern portion of the study area. 


\section{The Potential Influence of Changing Climate on the Persistence of Salmonids of the Inland West 7}

Table 1. Temperature thresholds used to characterize habitat suitability by taxon.

\begin{tabular}{lcccc}
\hline \multicolumn{1}{c}{ Taxon } & $\begin{array}{c}\text { Total temperature range } \\
\left({ }^{\circ} \mathrm{C}\right)\end{array}$ & $\begin{array}{c}\text { Suitable temperature } \\
\text { range }\left({ }^{\circ} \mathrm{C}\right)\end{array}$ & $\begin{array}{c}\text { Marginal temperature } \\
\text { range }\left({ }^{\circ} \mathrm{C}\right)\end{array}$ & $\begin{array}{c}\text { Unsuitable } \\
\text { temperature range } \\
\left({ }^{\circ} \mathrm{C}\right)\end{array}$ \\
\hline Westslope cutthroat & $5.9-24.2$ & $\leq 19.0$ & $19.1-22.0$ & $>22$ \\
Yellowstone cutthroat & $6.0-23.3$ & $\leq 21.0$ & $21.1-23.0$ & $>23$ \\
Bonneville cutthroat & $9.4-26.2$ & $\leq 22.0$ & $22.1-24.0$ & $>24$ \\
Colorado River & $5.3-24.7$ & $\leq 19.0$ & $19.1-22.0$ & $>22$ \\
cutthroat & $3.5-24.4$ & $\leq 19.0$ & $19.1-22.0$ & $>22$ \\
Greenback cutthroat & $5.8-23.3$ & $\leq 19.0$ & $19.1-22.0$ & $>22$ \\
Rio Grande cutthroat & $9.7-24.8$ & $\leq 22.0$ & $22.1-24.0$ & $>24$ \\
Lahontan cutthroat & $10.4-24.2$ & $\leq 21.0$ & $21.1-23.0$ & $>23$ \\
Apache & $12.5-27.5$ & $<22.0$ & $22.1-24.0$ & $>24$ \\
Gila & $13.0-20.5$ & $<19.0$ & $19.0-20.5$ & $>20.5$ \\
Arctic grayling & & & & \\
\hline
\end{tabular}

Our assessment of global warming influence applied a $3^{\circ} \mathrm{C}$ temperature increase to the 1970 2000 mean July air temperatures. The area-weighted average temperature under the global warming scenario was calculated for each subwatershed within the historic range of each species and subspecies analyzed. Using the species-specific 'suitable,' 'marginal,' and 'unsuitable' temperature breakpoints previously defined, we scored each subwatershed on the level of risk to the local populations from increased summer air temperatures: 1-suitable, low risk; 2-marginal, moderate risk; or 3unsuitable, high risk.

\section{Winter Flooding}

Our intent in this analysis was to identify those subwatersheds with an increased risk of uncharacteristic winter flooding as a direct result of warmer winter temperatures associated with climate change. We used the approach of Hamlet and Lettenmaier (2005) to analyze winter flood events for the western United States. Midwinter air temperature was used to classify watersheds with three types of winter precipitation regimes: rain dominant, snow dominant, and transient (between rain and snow). Winter flooding in a rain dominant watershed is a function of individual storm events and the size and characteristics of the catchment (such as antecedent moisture and vegetation cover). Winter flood events in these watersheds will not change because of rising temperatures without a corresponding increase in precipitation. Snow dominant watersheds do not typically flood in midwinter, but annual flood events occur as spring runoff. However, low- to mid-elevation snow dominant watersheds that lie near the freezing line may experience a change in runoff timing and characteristics associated with warmer winter air temperatures (McCabe and Dettinger, 2002). Transient watersheds, where both rain and snow precipitate in the winter months, are currently the primary location of significant winter flooding events for much of the western United States (Hamlet and Lettenmaier, 2005). The magnitude of these flood events depends on the intensity and duration of the rainstorm and the antecedent snowpack. 


\section{Methods}

Because our focus was on the risk of winter flood events altering channels and because we are not attempting to analyze changes in storm intensities, we initially relied on cumulative winter precipitation to identify low-risk areas. We assumed that watersheds receiving lower winter precipitation were less susceptible to large flood events than watersheds with more winter precipitation. To make this distinction, we used the average monthly precipitation data from Daly and others (2008) for 1970 to 2000 for the snow accumulation period of November-March (fig. 3). Total precipitation amounts were calculated for this five-month period and then reclassified into 10 groups using the 'natural breaks' methodology (Jenks, 1967). Data are grouped so that variance is minimized within groups and maximized between groups with this approach. If precipitation totals for the driest classification were $<11.2$ centimeters $(\mathrm{cm})$, they were considered to be at low risk for winter flooding.

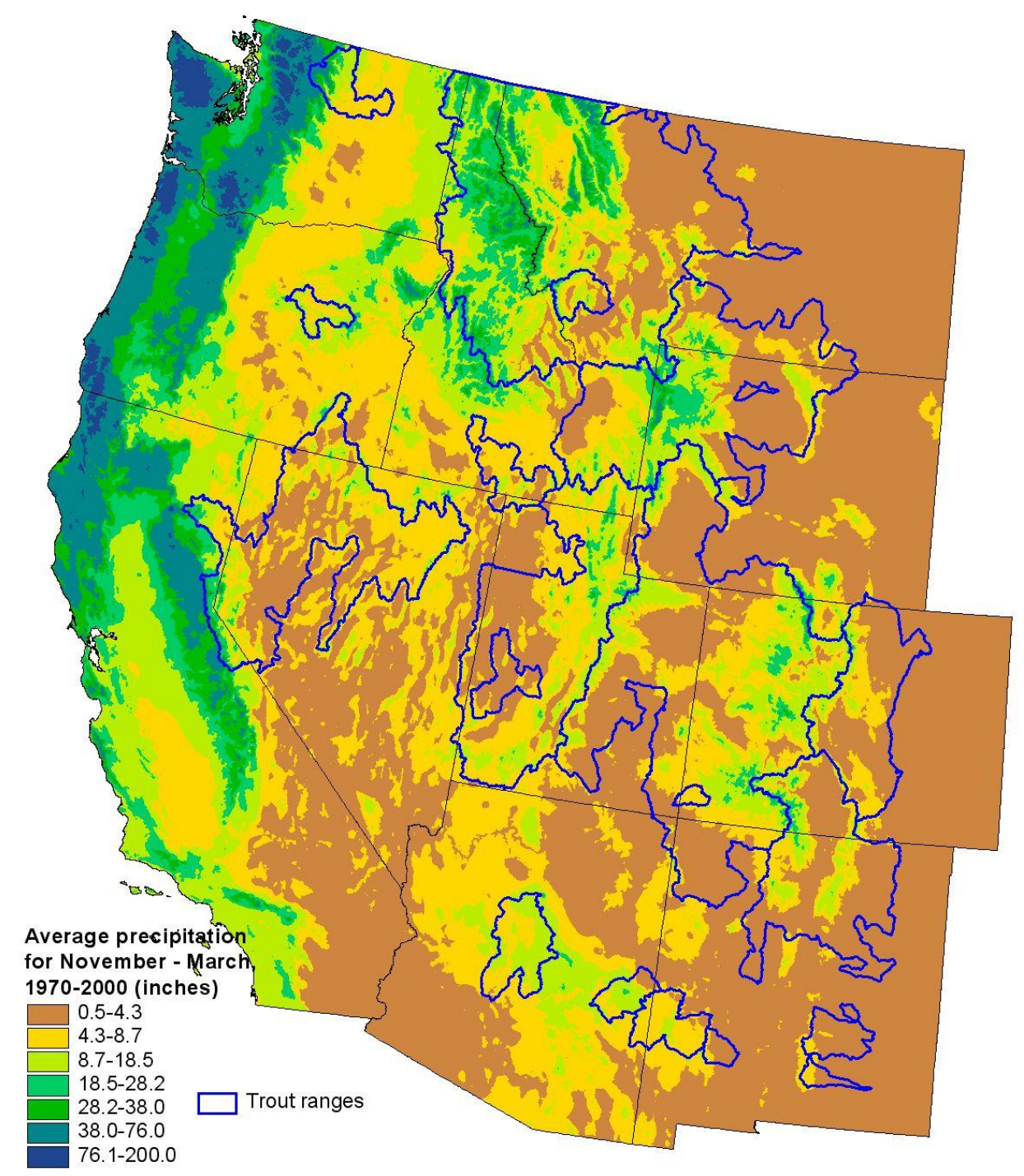

Figure 3. Average cumulative precipitation from November 1 to March 30, 1970-2000 (Daly and others, 2008). The dark brown areas (0.5-4.3 in) were considered a low risk for winter flooding due to limited winter precipitation. Native trout ranges (blue lines) show the variability in thermal conditions between the southwest and northern portion of the study area. 


\section{The Potential Influence of Changing Climate on the Persistence of Salmonids of the Inland West}

Areas receiving $>11.2 \mathrm{~cm}$ of winter precipitation were classified by watershed type according to average late winter temperatures. Specifically, we used the data from Daly and others (2008) for monthly average temperatures from 1970 to 2000 for the January-March timeframe. We used these late winter temperatures (January-March) rather than midwinter (December-February) because temperatures are generally warmer and the probability of a rain-on-snow event is greater at a time when snowpack is greatest in the mountainous regions. The mean temperature for the 3-month period was calculated for each watershed, and then each watershed was classified. Watersheds with a mean winter temperature less than $-1^{\circ} \mathrm{C}$ were classified as snow dominant, and those with a mean temperature greater than $+1^{\circ} \mathrm{C}$ were classified as rain dominant. Areas with mean winter temperatures between $-1^{\circ} \mathrm{C}$ and $+1^{\circ} \mathrm{C}$ were classified as transient. Increased risk of winter flooding from global warming was based on

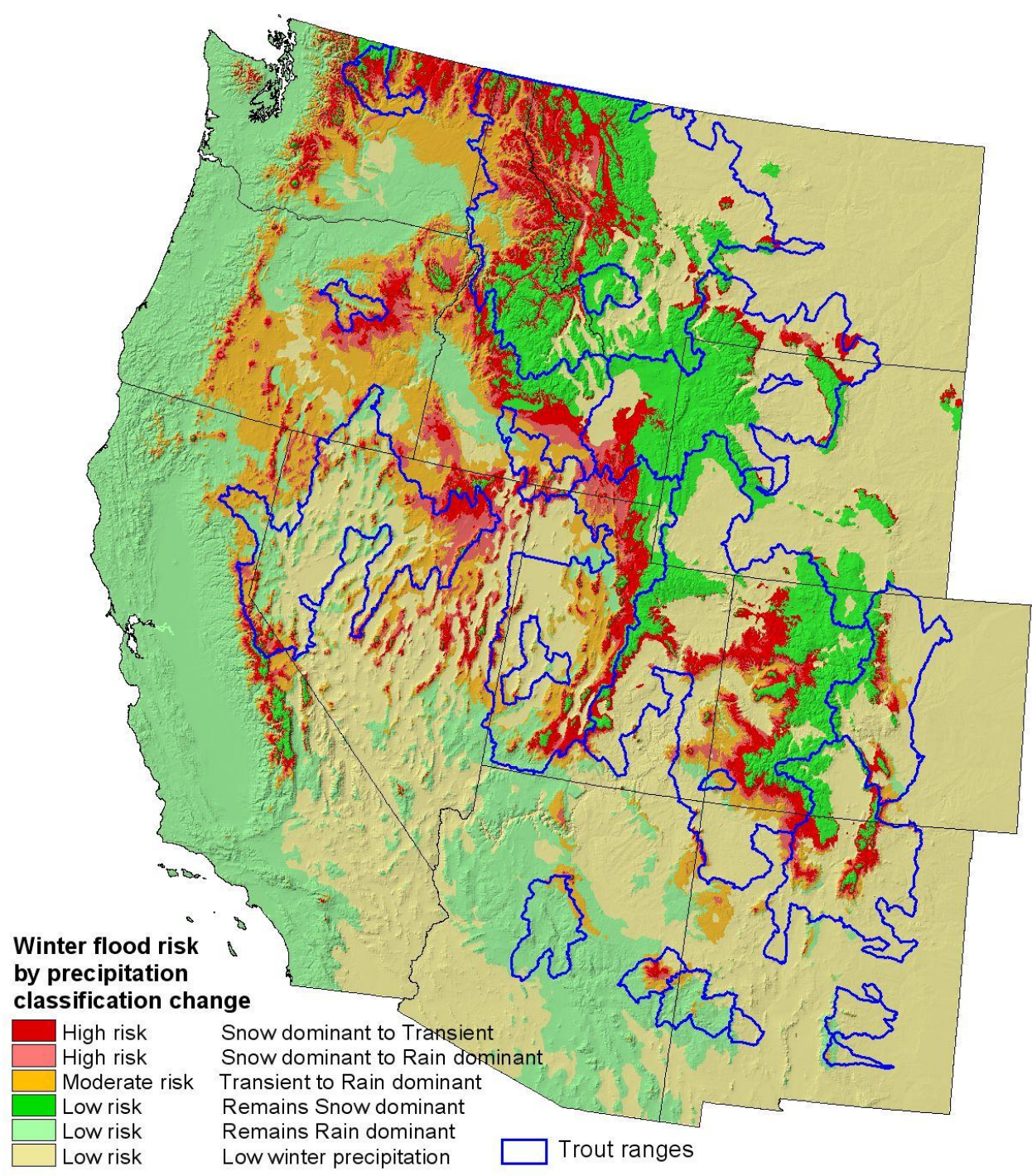

Figure 4. Results of winter flooding analysis. Areas in tan receive very little winter precipitation and are considered a low risk. The middle elevations show the highest risk because of increases in rain-on-snow events. Native trout ranges (blue lines) show the variability in thermal conditions between the southwest and northern portion of the study area. 
changes in winter precipitation type. Risk of change in winter precipitation regime was estimated by adding a $3^{\circ} \mathrm{C}$ to the current winter mean temperature of each watershed and then reclassifying. The greatest risk was assigned to watersheds that changed from snow dominant to transient or rain dominant systems (fig. 4). Watersheds that changed from transient to rain dominant were classified as a moderate risk because the risk of flooding would likely be higher in the near term while snow accumulation remains high and the frequency of warm midwinter storm events is increasing. These watersheds are predicted to eventually become rain dominant. Once a watershed has transitioned to rain dominant, winter flood risk may actually decline because the probability of an antecedent snowpack and associated high runoff potential diminishes. The cold, high-elevation mountains that are likely to remain snow dominant and the valley bottoms that are currently rain dominant were both classified as low risk. We recognize that downstream portions of watersheds may experience greater winter flows because of upstream events, but the complexity of dams and reservoir management makes it difficult to analyze downstream flood effects accurately.

\section{Wildfire}

Our analysis of wildfire risk does not incorporate temperature increase because wildfire ignition is not directly related to a temperature threshold in the way that temperature affects the occurrence of fish or form of precipitation (rain or snow). Rather, we assume that wildfire is a function of climate, fuels, and ignition and that changing climatic conditions for the western United States will continue to increase the likelihood of wildfires in the presence of fuels and an ignition source.

In order to define the spatial characteristics of wildfire risk, we assumed that fire frequency and duration (that is, total area burned) in forested regions were closely associated with timing of snowmelt (Westerling and others, 2006). Areas where snowmelt occurs early generally have more fires and a longer fire season because the forest's period of desiccation is longer. Westerling and others (2006) reported that the topographic zone of 1,680-2,690 meters $(\mathrm{m})$ recently had been prone to earlier snowmelt and more and larger wildfires (fig. 5). In each watershed, we classified landscapes above and below this zone as having low risk for wildfire, and areas within this zone (pink area on fig. 5) were subject to further analysis. Because these relationships were derived specifically for the Rocky Mountain region (Westerling and others, 2006), we did not include coastal areas in our analysis.

We used this topographic fire zone to define our wildfire risk assessment area. To further classify risk within the focal elevation zone, we relied on the Anderson Fire Behavior Fuel Model (Anderson, 1982) as updated by the LANDFIRE program (http://www.landfire.gov/NationalProduct Descriptions 1.php). This spatial data set identifies 13 different fuel types based on satellite imagery collected between 1999 and 2003 with a spatial resolution of $30 \mathrm{~m}$. Using the description of fire behavior associated with each fuel type, grassland and mesic shrublands were classified as low risk (score of 1) and all other fuel types were classified as high risk (score of 3). Nonfuel categories such as urban areas, agricultural lands, and barren ground were classified and given a score of zero (no fire risk). We then used a $5-\mathrm{km}^{2}$ moving window to calculate an average score for fire risk based on the fuels within a particular grid cell and the risk associated with adjacent grid cells (fig. 6). 


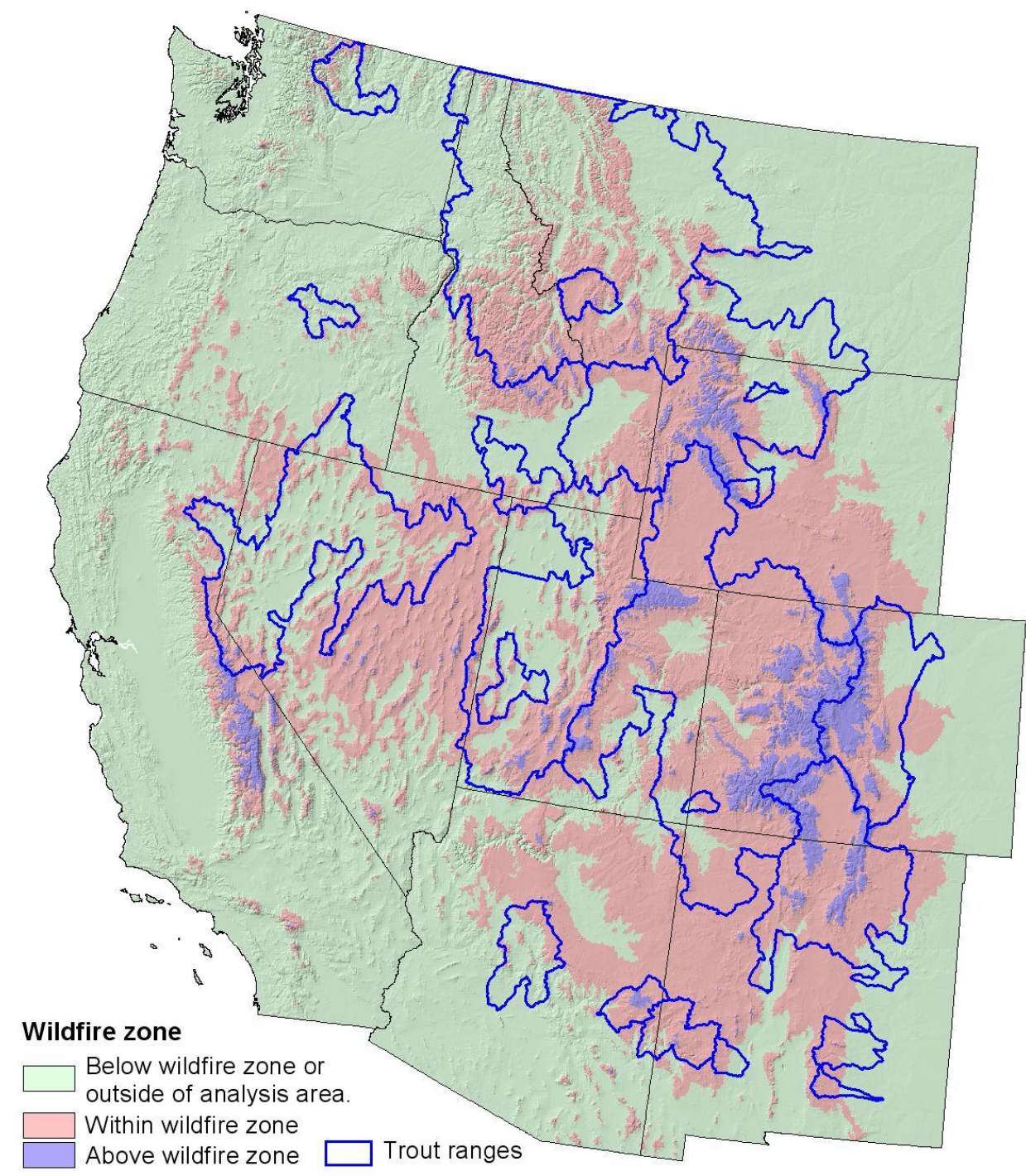

Figure 5. Distribution of the topographic zone of $1,680-2,690$ meters (shaded in pink) defined by Westerling and others (2006) as experiencing the greatest increase in area burned. Native trout ranges (blue lines) show the variability in thermal conditions between the southwest and northern portions of the study area. 


\section{Methods}

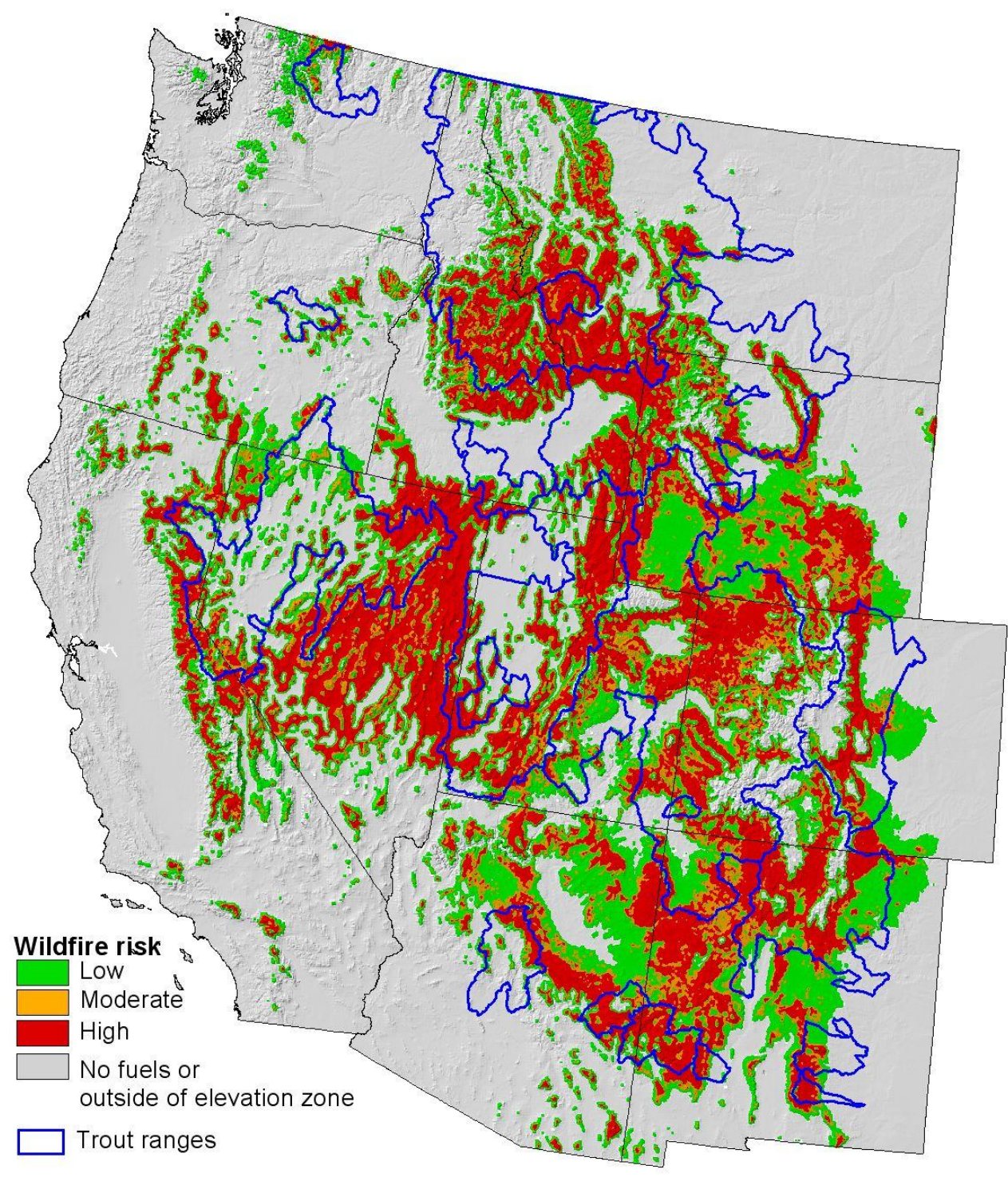

Figure 6. Results of LANDFIRE wildfire analysis. Red shading indicates areas with high risk for wildfire. Native trout ranges (blue lines) show the variability in thermal conditions between the southwest and northern portion of the study area. 


\section{Drought}

Our analysis of increased drought risk related to climate change is based on Hoerling and Eischeid (2007). Using the Palmer Drought Severity Index (PDSI) to model drought risk across the western United States for the period 2035-2060, Hoerling and Eischeid (2007) predicted that heatrelated moisture loss will overwhelm potential increases in precipitation related to global warming, and as a result, an unprecedented, nearly perpetual state of drought will occur across much of the region (fig. 7). In order to downscale these data (reported by climate division, 60,000-12,000,000 hectares [ha]), mean annual precipitation (1970-2000) and elevation were used to identify local conditions that could mitigate the effects of regional drought due to heat-related moisture loss.

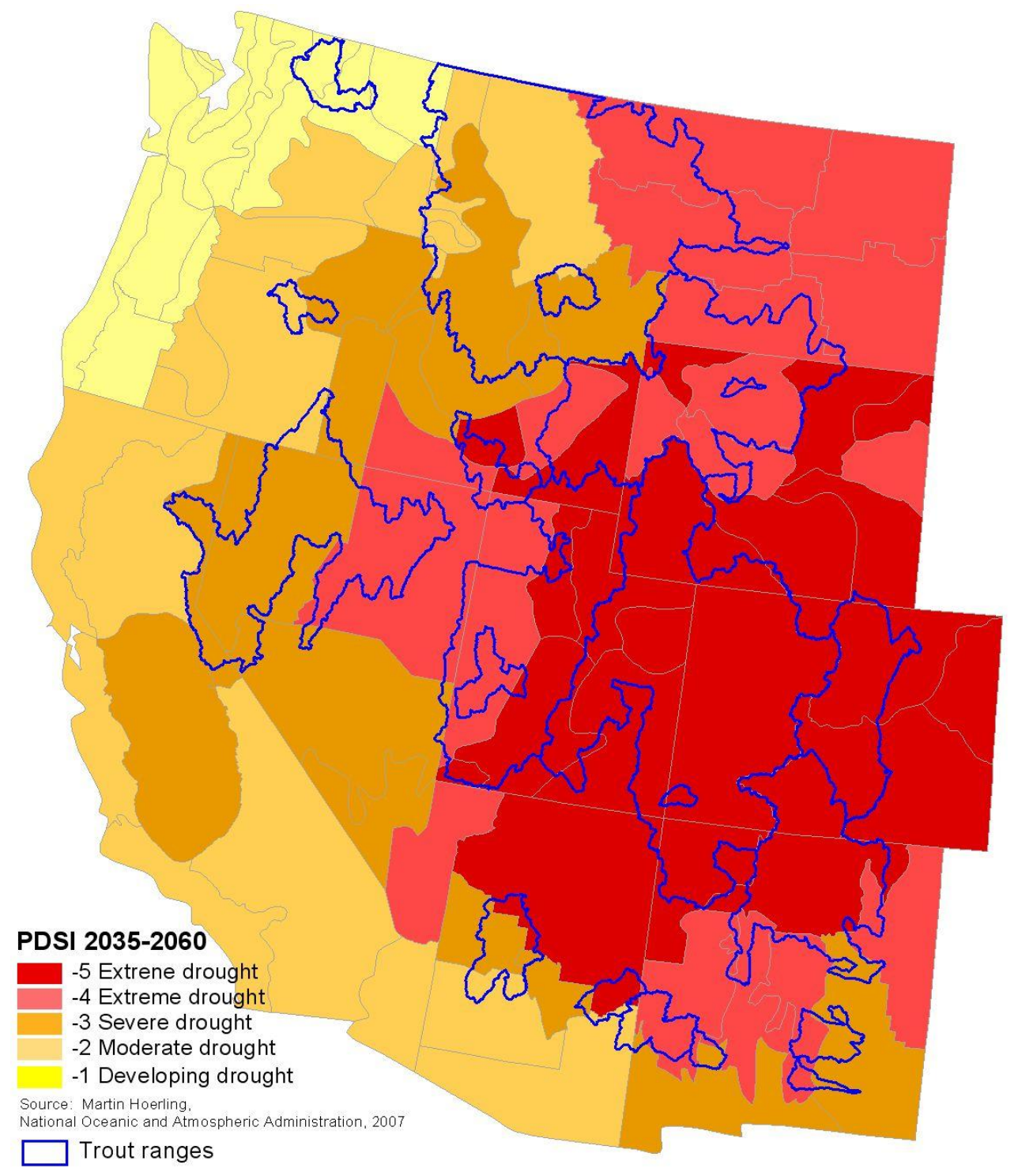

Figure 7. Projection of Palmer Drought Severity Index (PDSI) by climate division for the period 2035-2060 by Hoerling and Eischeid (2007). Native trout ranges (blue lines) show the variability in thermal conditions between the southwest and northern portion of the study area. 
The PDSI is reported by climate divisions developed by the National Climatic Data Center (NCDC) to represent areas of similar climate, but the divisions include political boundaries. In order to minimize the artificial effects of political boundaries, we modified the climate divisions to conform to subbasin (4th field Hydrologic Unit Code) delineations. In situations where a subbasin was split by a climate division, we assigned the entire subbasin to the division covering the largest portion of the subbasin. The five levels of drought severity in the Hoerling and Eischeid (2007) forecast were reclassified into five risk categories as follows:

- -1 - developing drought—low risk,

- -2 - moderate drought - moderate risk,

- -3 - severe drought - moderate risk,

- -4 - extreme drought - high risk, and

- -5-extreme drought - high risk.

Because the PDSI was originally developed for use in Midwestern States where topography is uniform, it does not capture the regional microclimates associated with mountainous terrain in the western United States. Therefore, we used the 1,680-2,690 m topographic zone (Westerling and others, 2006) to modify initial predictions. We assumed that elevations above $2,690 \mathrm{~m}$ were less prone to prolonged drought because the snowpack extends into the spring and provides greater base streamflow during the dry summer months. In order to extend the timeframe from current conditions (Westerling and others, 2006) to the year 2060, we applied a $3^{\circ} \mathrm{C}$ temperature increase to the upper limits of the current snowmelt zone $\left(2,690 \mathrm{~m}\right.$; assuming a normal lapse rate of $\left.6.5^{\circ} \mathrm{C} / 1,000 \mathrm{~m}\right)$. Areas between 2,690 $\mathrm{m}$ and 3,190 $\mathrm{m}$ elevation were classified as moderate risk to future drought, and areas above 3,190 m were considered low risk. Elevations below 2,690 m were assigned a drought severity level according to the PDSI forecast.

In addition to the mitigating effect of snowpack retention in high elevations, we also incorporated mean annual precipitation as a local factor that might alleviate regional drought conditions. Our objective was to identify anomalies within the climate divisions where the effects of heat-related moisture loss on streamflows are reduced because precipitation greatly exceeds that of the surrounding region. The mean annual precipitation for 1970-2000 (Daly and others, 2008) was used for this portion of the analysis. The mean precipitation for the interior western United States was $41 \mathrm{~cm}$; one standard deviation was $64 \mathrm{~cm}$ and the second standard deviation was $89 \mathrm{~cm}$. We reclassified mean annual precipitation into the following three drought risk categories:

- $>3$ standard deviations $(>89 \mathrm{~cm})$ - low risk;

- 1-2 standard deviations (64-89 cm) - moderate risk; and

- $\quad<64 \mathrm{~cm}$-no mitigating effects.

After classifying each of the three variables (PDSI, elevation, and precipitation) into risk categories, drought risk was determined using the lowest risk from each of the three variables. For example, a PDSI of high risk for a low elevation that receives $102 \mathrm{~cm}$ of rain would receive a low risk score because of the mitigating effects of the wet climate. Because the PDSI was considered to represent the worst-case scenario, no area received a higher risk than the PDSI score regardless of precipitation or elevation (fig. 8). 


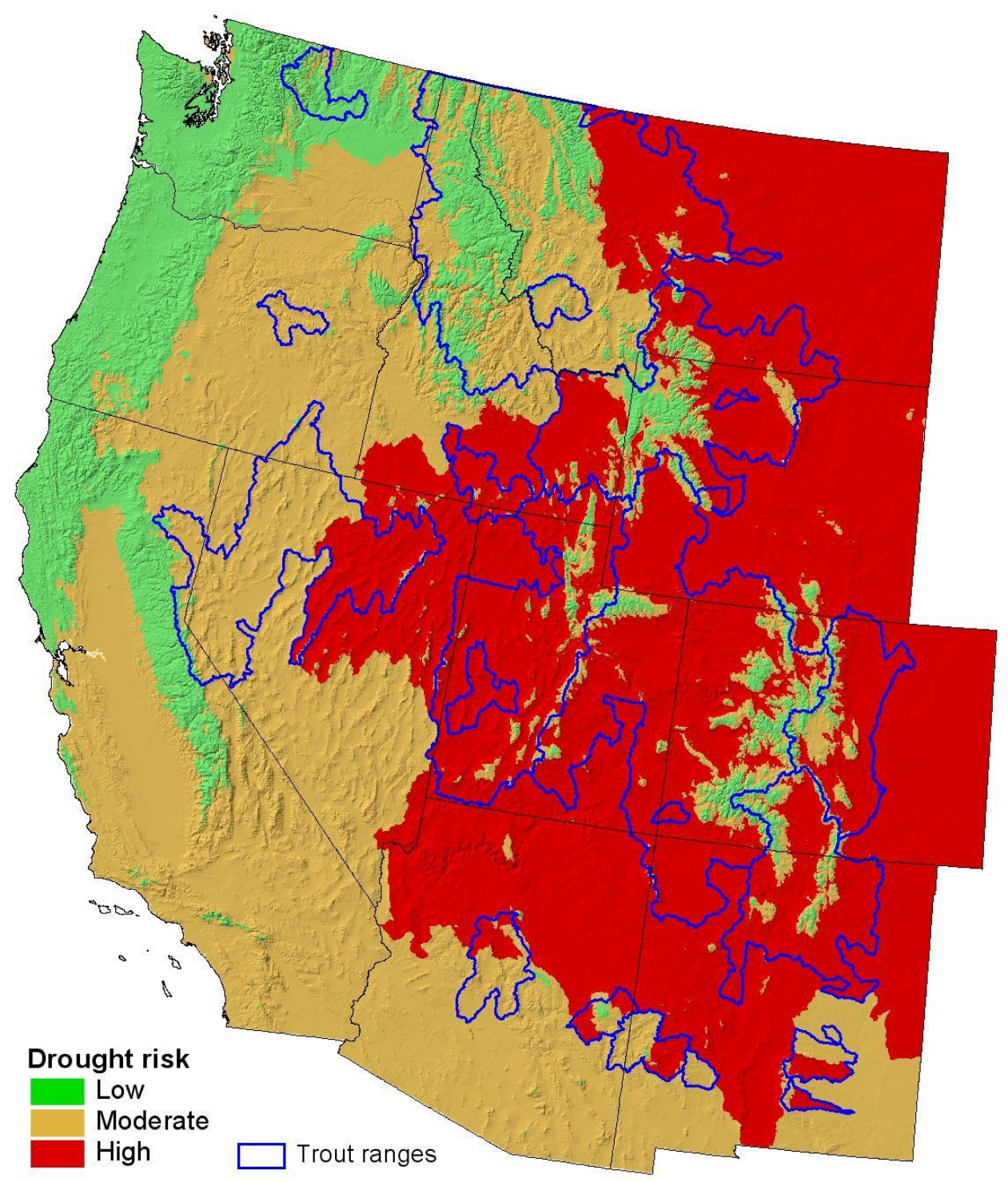

Figure 8. Results of modified drought risk forecast for year 2060. This forecast uses the Hoerling and Eischeid (2007) PDSI 2060 forecast as the foundation, but includes data on elevation and precipitation. Native trout ranges (blue lines) show the variability in thermal conditions between the southwest and northern portion of the study area. 


\section{Analysis}

Our analysis of population vulnerability combines the results of the climate change evaluation with a population-specific assessment of persistence for each taxon. Analysis for cutthroat trout subspecies (with the exception of greenback cutthroat trout) was based on conservation populations as defined in the range-wide status assessments (May and others, 2007). A conservation population represents a subset of the current distribution of an individual taxon that has high conservation value and therefore represents a priority for recovery efforts. In general, a conservation population represents a group of genetically pure individuals or a unique life-history form. We used population-specific data on distribution and abundance when available in a published recovery plan, or we relied on local expert knowledge from the State agencies. All populations of greenback cutthroat trout, Montana Arctic grayling, Gila trout, and Apache trout were considered conservation populations. Population persistence was assessed separately for small streams (Hilderbrand and Kershner, 2000) and for larger rivers or coupled stream networks (Dunham and Rieman, 1999). In general, persistence criteria examine whether sufficient habitat is available to support an effective population size of at least 500 spawning adults, which is usually equivalent to a census population of at least 1,000 adults. All populations with a habitat patch size $>5,000$ ha and an extent of at least $13.9 \mathrm{~km}$ of stream habitat were considered persistent (see Williams and others, 2009). Populations occupying a habitat patch $<5,000$ ha or an extent of $<13.9 \mathrm{~km}$ of stream habitat were considered persistent if they satisfied the following combinations of stream habitat availability and population density: $9.3-13.9 \mathrm{~km}$ stream habitat with high density (>93 fish/km); 13.9-27.8 km habitat with moderate density ( $>31 \mathrm{fish} / \mathrm{km}$ ); or $>27.8 \mathrm{~km}$ of habitat at any density. Populations with $<9.3 \mathrm{~km}$ of stream habitat were classified as "at risk" regardless of fish density. Table 2 summarizes our persistence criteria. All populations not meeting these criteria were classified as not persistent.

Table 2. Criteria for determining population persistence. [ha, hectare; km, kilometer. Population density: moderate, $>31 \mathrm{fish} / \mathrm{km}$; high, $>93 \mathrm{fish} / \mathrm{km}]$

\begin{tabular}{ccl}
\hline Patch size (ha) & Stream habitat $(\mathbf{k m})$ & Population density \\
\hline$\geq 5,000$ & $\geq 13.9$ & any \\
$<5,000$ & $\geq 27.8$ & any \\
$<5,000$ & $13.9-27.8$ & moderate-high \\
any & $9.3-13.9$ & high \\
\hline
\end{tabular}

Subsequent to the initial persistence classification, climate change risk was assessed using the coarse filter assessment to determine population vulnerability. For populations that extended into multiple subwatersheds, we estimated a length-weighted average score for each of the four risk factors and assigned it to the entire population. 


\section{Results}

Climate change risk factors were summarized for each species and subspecies. Our broad-scale analysis of climate change risk factors is largely determined by the integration of a changing climate with varying landscape conditions such as elevation and aspect. Existing watershed, riparian, and stream conditions are often important at local scales in determining risk from climate change.

\section{Montana Arctic Grayling}

Historically occupied habitat for the Montana Arctic grayling is divided between 62 subwatersheds in the Missouri-Marias River Basin and 130 subwatersheds in the Missouri Headwaters Basin. Nineteen of the remaining 20 conservation populations are located in the Missouri Headwaters Basin.

The risk from winter flooding is generally low throughout the entire historic range of the Montana Arctic grayling (fig. 9), and 19 of 20 conservation populations are classified at low risk for winter flooding (table 3). Wildfire is a greater concern in the Missouri Headwaters Basin, and 13 of 19 conservation populations in that basin were classified as high risk. The remaining six conservation populations were considered at low risk for wildfire (fig. 9). Risk for drought is high throughout the Missouri-Marias, and the single conservation population in that basin is rated at high risk of drought. Drought risk was rated as moderate through most of the Missouri Headwaters. A total of 13 of 19 populations in that basin are at moderate risk for drought, and the remaining six at low risk (fig. 10). 


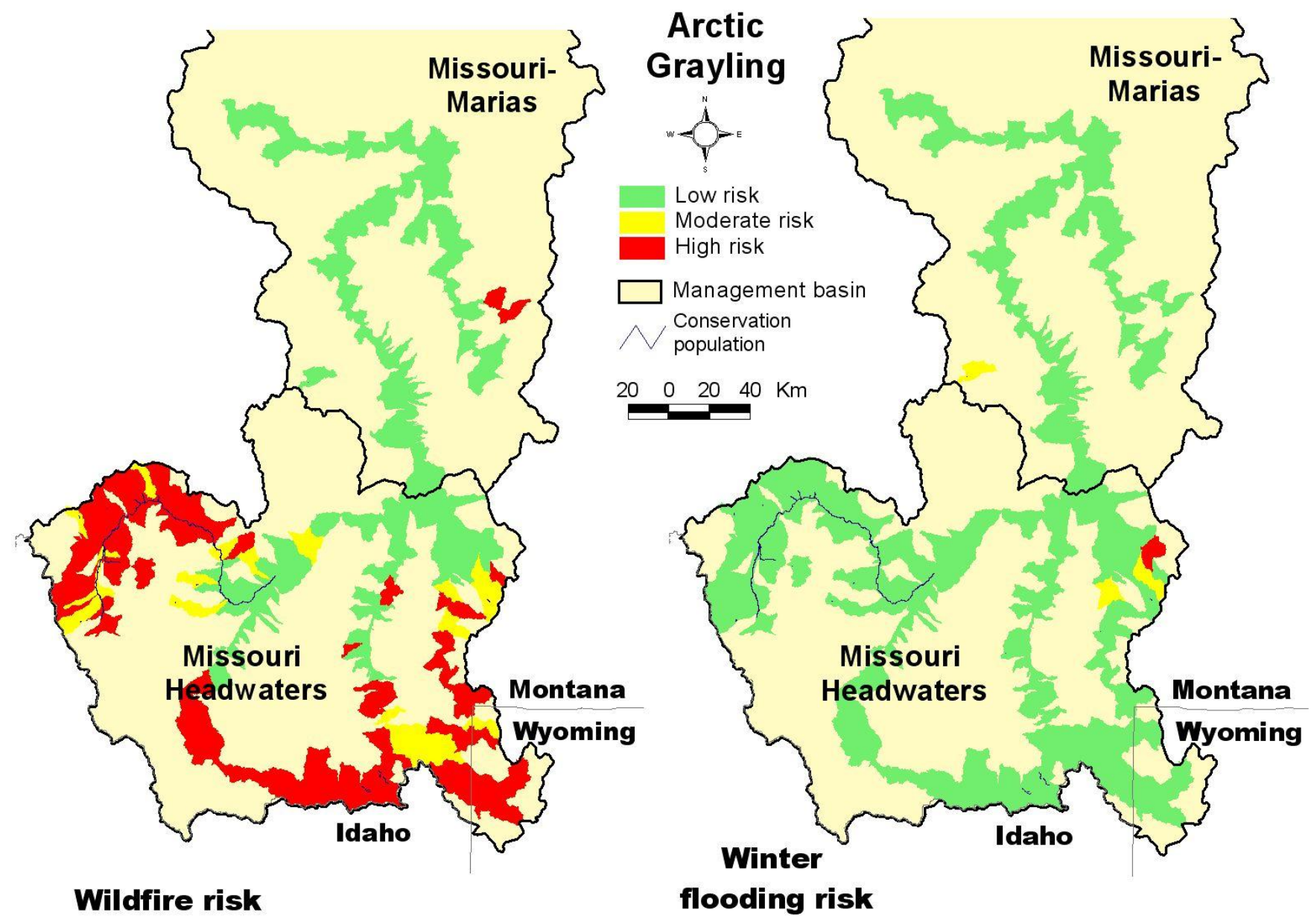

Figure 9. Risk of wildfire and winter flooding for Montana Arctic grayling in their current range. 


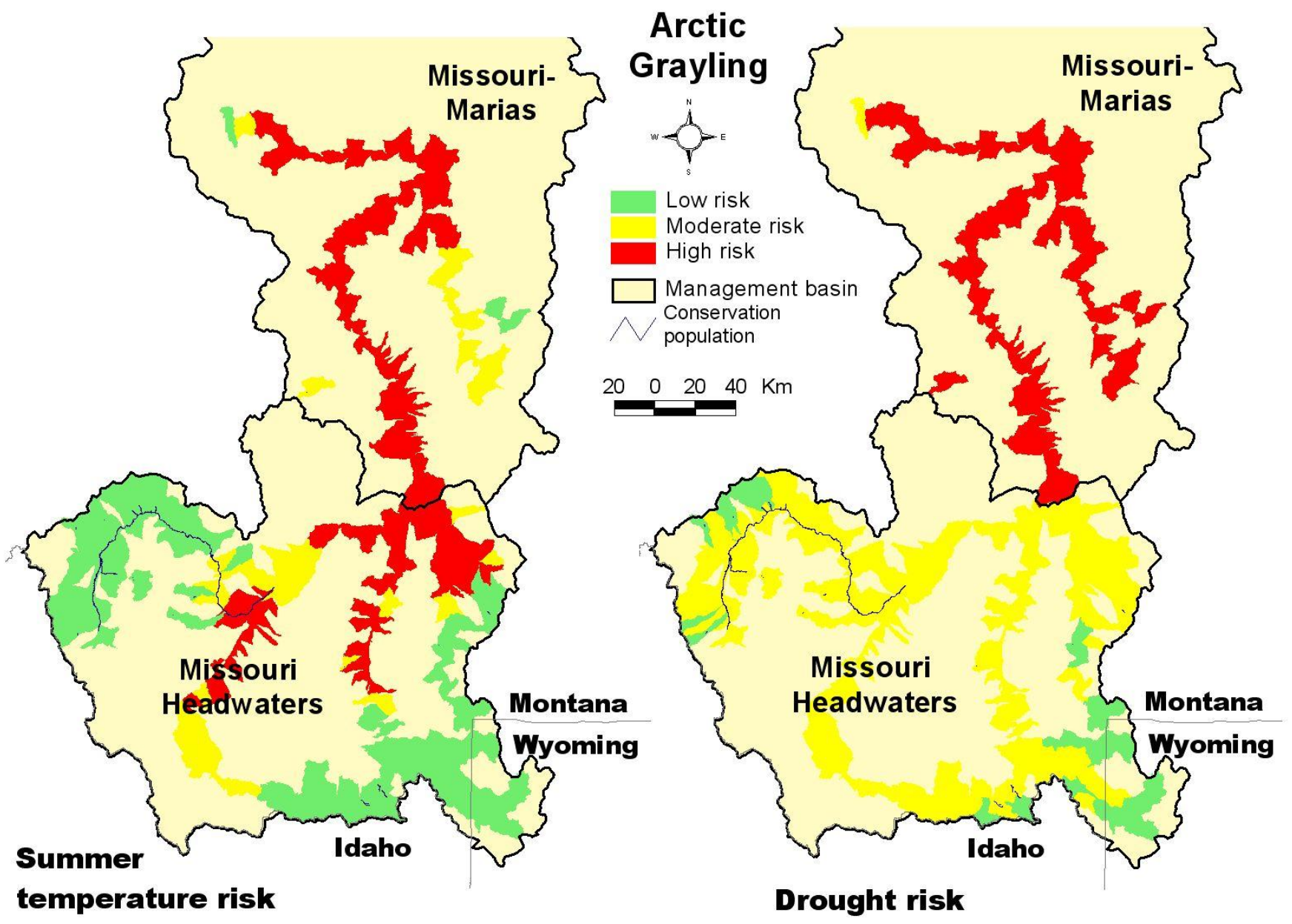

Figure 10. Risk of summer temperature increases and drought for Montana Arctic grayling in their current range. 
Table 3. Ratings for increased risk from winter floods, wildfire, drought, and increased summer temperatures for subwatersheds and conservation populations of Montana Arctic grayling.

\begin{tabular}{|c|c|c|c|c|c|c|c|c|c|c|c|c|c|}
\hline \multicolumn{14}{|c|}{ Currently occupied subwatersheds } \\
\hline & \multicolumn{3}{|c|}{ Flood risk } & \multicolumn{3}{|c|}{ Fire risk } & \multicolumn{3}{|c|}{ Drought risk } & \multicolumn{3}{|c|}{ Temperature risk } & \multirow[t]{2}{*}{ Total populations } \\
\hline Management basin & High & Mod & Low & High & Mod & Low & High & Mod & Low & High & Mod & Low & \\
\hline Missouri Headwaters & 0 & 0 & 37 & 24 & 8 & 5 & 0 & 31 & 6 & 3 & 5 & 29 & 37 \\
\hline Missouri-Marias & 0 & 1 & 0 & 0 & 0 & 1 & 1 & 0 & 0 & 0 & 1 & 0 & 1 \\
\hline TOTAL & $\mathbf{0}$ & 1 & 37 & 24 & 8 & 6 & $\mathbf{1}$ & 31 & 6 & 3 & 6 & 29 & 38 \\
\hline \multicolumn{14}{|c|}{ Historically occupied subwatersheds } \\
\hline & \multicolumn{3}{|c|}{ Flood risk } & \multicolumn{3}{|c|}{ Fire risk } & \multicolumn{3}{|c|}{ Drought risk } & \multicolumn{3}{|c|}{ Temperature risk } & Total populations \\
\hline Management basin & High & Mod & Low & High & Mod & Low & High & Mod & Low & High & Mod & Low & \\
\hline Missouri Headwaters & 2 & 3 & 125 & 75 & 19 & 36 & 0 & 107 & 23 & 30 & 22 & 78 & 130 \\
\hline Missouri-Marias & 0 & 0 & 62 & 2 & 1 & 59 & 60 & 2 & 0 & 47 & 11 & 4 & 62 \\
\hline TOTAL & 2 & 3 & 187 & 77 & 20 & 95 & 60 & 109 & 23 & 77 & 33 & 82 & 192 \\
\hline \multicolumn{14}{|c|}{ Conservation populations } \\
\hline & \multicolumn{3}{|c|}{ Flood risk } & \multicolumn{3}{|c|}{ Fire risk } & \multicolumn{3}{|c|}{ Drought risk } & \multicolumn{3}{|c|}{ Temperature risk } & Total populations \\
\hline Management basin & High & Mod & Low & High & Mod & Low & High & Mod & Low & High & Mod & Low & \\
\hline Missouri Headwaters & 0 & 0 & 19 & 13 & 6 & 0 & 0 & 13 & 6 & 0 & 2 & 17 & 19 \\
\hline Missouri-Marias & 0 & 1 & 0 & 0 & 0 & 1 & 1 & 0 & 0 & 0 & 1 & 0 & 1 \\
\hline TOTAL & $\mathbf{0}$ & 1 & 19 & 13 & 6 & 1 & 1 & 13 & 6 & 0 & 3 & 17 & 20 \\
\hline
\end{tabular}


Unlike many remaining enclaves of native trout that are located at higher elevations and are somewhat buffered from increasing summer temperature, the historic range of Montana Arctic grayling includes many larger, lower elevation river systems that are vulnerable to thermal risks. Nonetheless, remaining conservation populations are primarily upstream of the highest risk areas in the Missouri Headwaters. Moreover, summer temperature is a moderate risk for 3 of 20 conservation populations and a low risk for the remaining 17.

Our persistence analysis indicated that only 2 of 20 conservation populations of Montana Arctic grayling met persistence criteria (table 4). Of 14 populations that rated high for at least one climate risk factor, only one met persistence criteria. The lone conservation population in the Missouri-Marias Basin was at high risk for drought and failed to meet persistence criteria.

Table 4. Comparison of climate change risk and persistence in populations of Montana Arctic grayling.

\begin{tabular}{llccc}
\hline \multicolumn{5}{c}{ Climate change risk } \\
\hline Management basin & & High & Mod-Low & Total \\
Missouri Headwaters & Persistent & 1 & 1 & 2 \\
& Not persistent & 12 & 5 & 17 \\
\multirow{2}{*}{ Missouri-Marias } & Persistent & 0 & 0 & 0 \\
\multirow{2}{*}{ TOTAL } & Not persistent & 1 & 0 & 1 \\
\hline
\end{tabular}

\section{Apache Trout}

Most remaining populations of Apache trout occupy high-elevation streams in the Little Colorado River, upper Gila River, and Salt River systems. Only 20 of 62 subwatersheds within the historic range are currently occupied. In general, our analysis showed that these high-elevation streams have the greatest risk of winter flooding, low to moderate risk of drought and wildfire, and the lowest risk of increased summer temperature (figs. 11, 12). Streams on the north-facing slopes of Mt. Baldy tended to have a lower risk for drought and wildfire, but those on the more southerly exposures rated at a higher risk for these factors. Fifty-seven percent of populations (21 of 37) were rated at high risk for winter flooding (table 5). All but one of 37 conservation populations occurred in subwatersheds rated as having a high or moderate risk for winter flooding. 


\section{$22 \mid$ Results}

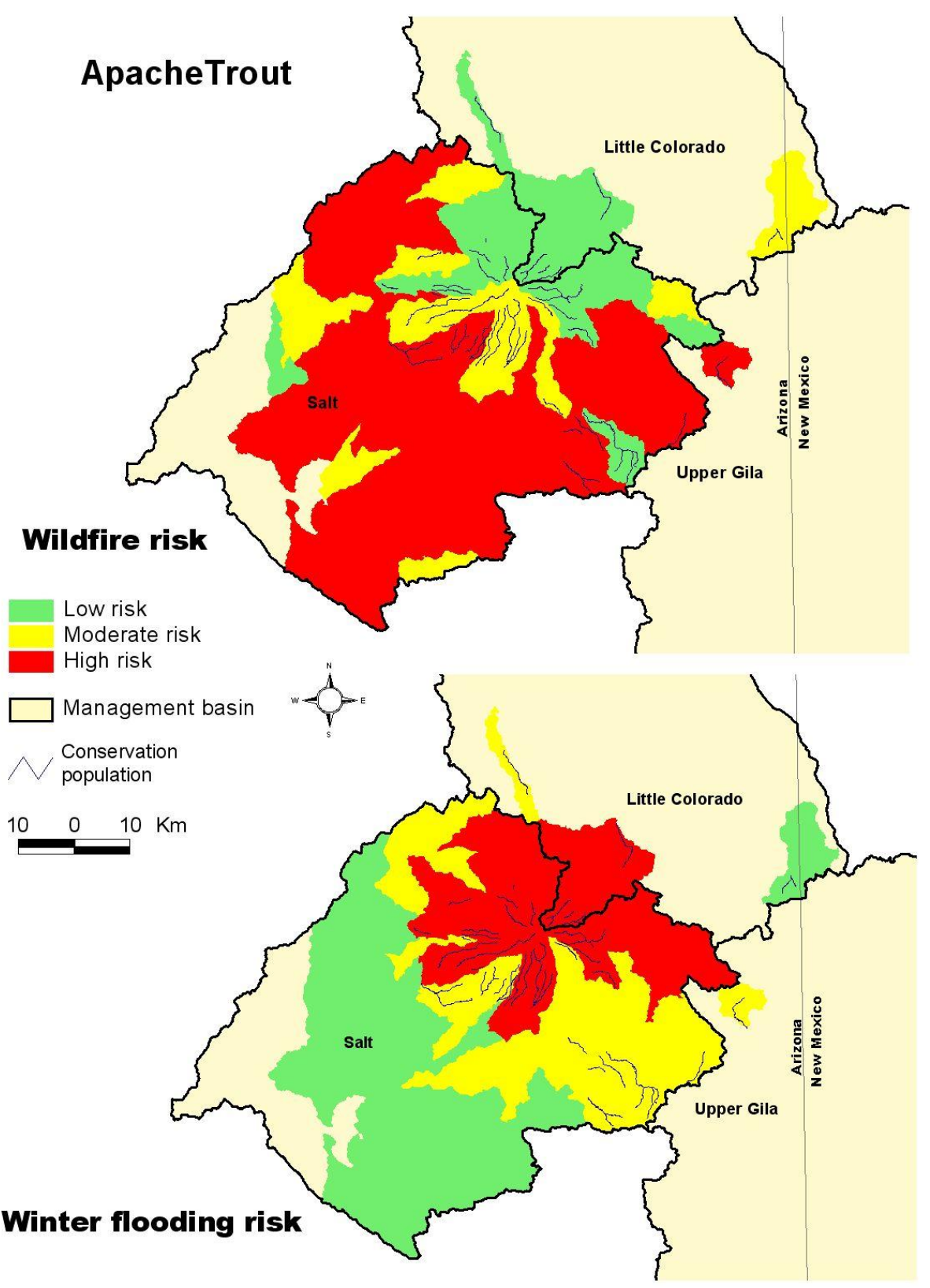

Figure 11. Risk of wildfire and winter flooding for Apache trout in their current range. 

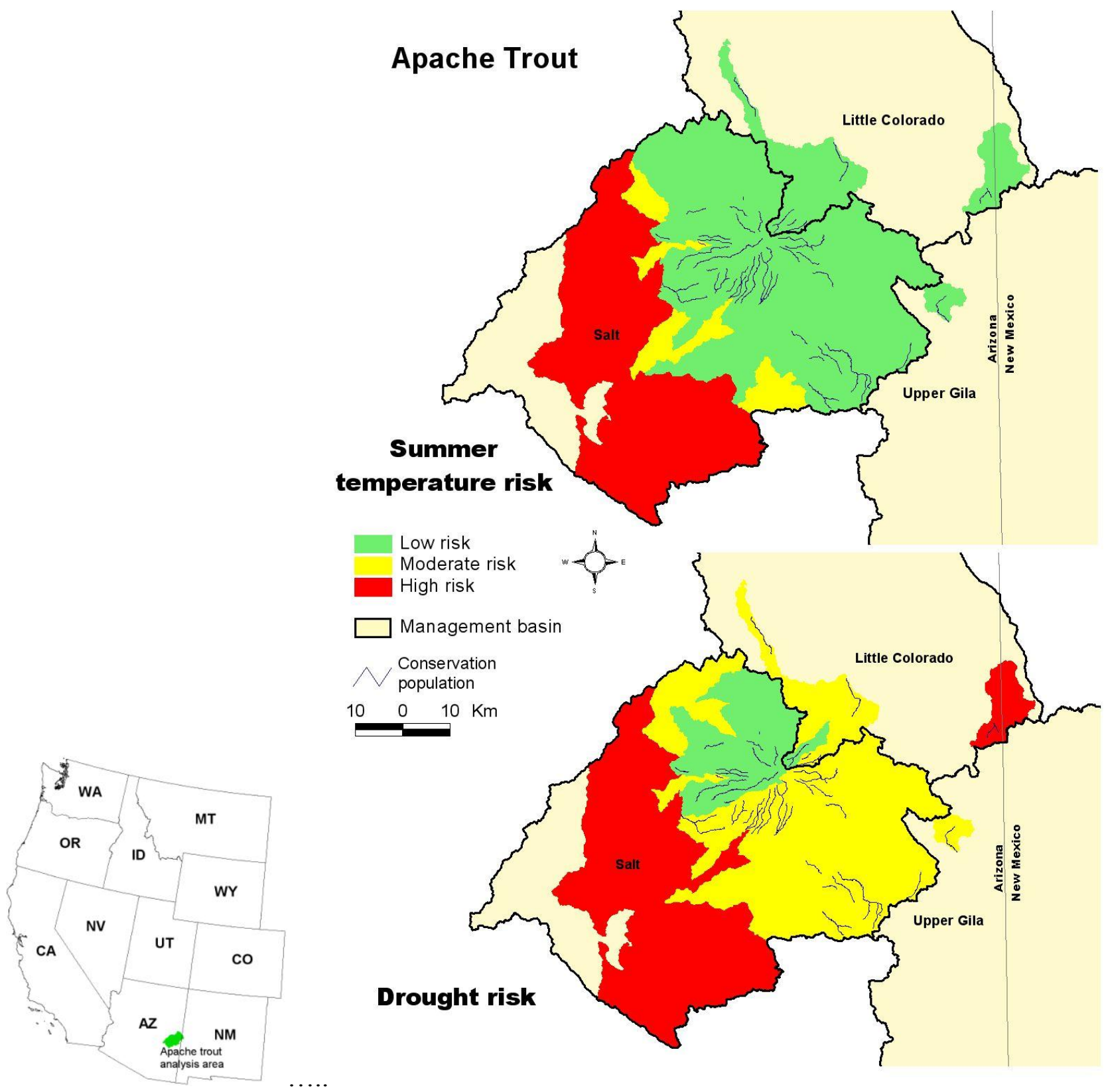

Figure 12. Risk of summer temperature increases and drought for Apache trout in their current range. 
Table 5. Ratings for increased risk from winter floods, wildfire, drought, and increased summer temperatures to subwatersheds and conservation populations of Apache trout.

\begin{tabular}{|c|c|c|c|c|c|c|c|c|c|c|c|c|c|}
\hline \multicolumn{14}{|c|}{ Currently occupied subwatersheds } \\
\hline & \multicolumn{3}{|c|}{ Flood risk } & \multicolumn{3}{|c|}{ Fire risk } & \multicolumn{3}{|c|}{ Drought risk } & \multicolumn{3}{|c|}{ Temperature risk } & $\begin{array}{c}\text { Total } \\
\text { populations }\end{array}$ \\
\hline $\begin{array}{c}\text { Management } \\
\text { basin }\end{array}$ & High & Mod & Low & High & Mod & Low & High & Mod & Low & High & Mod & Low & \\
\hline $\begin{array}{l}\text { Little } \\
\text { Colorado }\end{array}$ & 2 & 1 & 1 & 0 & 1 & 3 & 1 & 2 & 1 & 0 & 0 & 4 & 4 \\
\hline Upper Gila & 0 & 1 & 0 & 1 & 0 & 0 & 0 & 1 & 0 & 0 & 0 & 1 & 1 \\
\hline Salt & 7 & 8 & 0 & 6 & 4 & 5 & 0 & 10 & 5 & 0 & 1 & 14 & 15 \\
\hline TOTAL & 9 & 10 & 1 & 7 & 5 & 8 & 1 & 13 & 6 & $\mathbf{0}$ & 1 & 19 & 20 \\
\hline \multicolumn{14}{|c|}{ Historically occupied subwatersheds } \\
\hline & \multicolumn{3}{|c|}{ Flood risk } & \multicolumn{3}{|c|}{ Fire risk } & \multicolumn{3}{|c|}{ Drought risk } & \multicolumn{3}{|c|}{ Temperature risk } & $\begin{array}{c}\text { Total } \\
\text { populations }\end{array}$ \\
\hline $\begin{array}{c}\text { Management } \\
\text { basin }\end{array}$ & High & Mod & Low & High & Mod & Low & High & Mod & Low & High & Mod & Low & \\
\hline $\begin{array}{l}\text { Little } \\
\text { Colorado }\end{array}$ & 5 & 0 & 0 & 0 & 0 & 5 & 0 & 4 & 1 & 0 & 0 & 5 & 5 \\
\hline Upper Gila & 0 & 0 & 0 & 0 & 0 & 0 & 0 & 0 & 0 & 0 & 0 & 0 & 0 \\
\hline Salt & 15 & 18 & 24 & 37 & 10 & 10 & 23 & 25 & 9 & 21 & 5 & 31 & 57 \\
\hline TOTAL & 20 & 18 & 24 & 37 & 10 & 15 & 23 & 29 & 10 & 21 & 5 & 36 & 62 \\
\hline \multicolumn{14}{|c|}{ Conservation populations } \\
\hline & \multicolumn{3}{|c|}{ Flood risk } & \multicolumn{3}{|c|}{ Fire risk } & \multicolumn{3}{|c|}{ Drought risk } & \multicolumn{3}{|c|}{ Temperature risk } & $\begin{array}{c}\text { Total } \\
\text { populations }\end{array}$ \\
\hline $\begin{array}{c}\text { Management } \\
\text { basin }\end{array}$ & High & Mod & Low & High & Mod & Low & High & Mod & Low & High & Mod & Low & \\
\hline $\begin{array}{l}\text { Little } \\
\text { Colorado }\end{array}$ & 4 & 1 & 1 & 0 & 1 & 5 & 1 & 4 & 1 & 0 & 0 & 6 & 6 \\
\hline Upper Gila & 0 & 1 & 0 & 1 & 0 & 0 & 0 & 1 & 0 & 0 & 0 & 1 & 1 \\
\hline Salt & 17 & 13 & 0 & 10 & 9 & 11 & 0 & 20 & 10 & 0 & 1 & 29 & 30 \\
\hline TOTAL & 21 & 15 & 1 & 11 & 10 & 16 & 1 & 25 & 11 & $\mathbf{0}$ & 1 & 36 & 37 \\
\hline
\end{tabular}


Eleven conservation populations (30 percent) were rated at high risk for wildfire. Most of these populations were located along the south flanks of Mt. Baldy in streams draining the Salt River system. At low- to mid-elevations of the historic range, where few conservation populations currently exist, risks increase from wildfire, drought, and summer temperature. Increasing summer temperature was a significant risk only at the lowest elevations within the historic range. Risks tend to decrease with increasing elevation for all factors except winter flooding, where risks are highest near the peak of Mt. Baldy. Although risks varied substantially with elevation and aspect, all areas were classified as high risk for at least one of the four factors. Nonetheless, higher elevation populations draining streams on the north and northwest face of Mt. Baldy appear to be at lowest relative risk.

Because of small population size and limited habitat, 25 of the 37 conservation populations of Apache trout (68 percent) failed to meet persistence criteria (table 6$)$. Of the 33 populations that were ranked at high risk for one or more climate change risk factors, 11 (33 percent) met persistence criteria. All of these populations meeting persistence criteria were located in the Salt River Basin.

Table 6. Comparison of climate change risk and persistence in populations of Apache trout.

\begin{tabular}{llccc}
\hline \multicolumn{5}{c}{ Climate change risk } \\
\hline Management basin & & High & Mod-Low & Total \\
Little Colorado & Persistent & 0 & 0 & 0 \\
& Not persistent & 5 & 1 & 6 \\
Salt & Persistent & 11 & 1 & 12 \\
& Not persistent & 16 & 2 & 18 \\
Upper Gila & Persistent & 0 & 0 & 0 \\
& Not persistent & 1 & 0 & 1 \\
TOTAL & & $\mathbf{3 3}$ & $\mathbf{4}$ & $\mathbf{3 7}$ \\
\hline
\end{tabular}

\section{Gila Trout}

Historic habitat of Gila trout occurs in two disjunct patches: one area of the upper Gila River, primarily in New Mexico, and a second area primarily in the Verde River drainage and lower Gila River system in Arizona. Nearly all remaining conservation populations are located in the tributaries of the upper Gila River in New Mexico. In the upper Gila River, wildfire, drought, and increasing summer temperatures are high to moderate risk factors (figs. 13, 14). Drought is a substantial risk factor: seven populations are rated at high risk, six at moderate risk, and none at low risk. Increasing summer temperature is a high risk for one population, a moderate risk for another eight, and a low risk for four. Of the subwatersheds containing conservation populations, 9 (77 percent) are at high risk from wildfire (table 7). Increasing summer temperature is rated a high risk for 1 of 13 conservation populations and moderate risk for another 9. All 13 conservation populations are rated at low risk for winter flooding. In the Arizona portion of the historic range in the Verde and lower Gila Rivers, drought and increasing summer temperature are high risk factors throughout most historic habitat area and a moderate risk in nearly all of the remaining area. Ten of 13 populations were classified at high risk for at least one factor. 

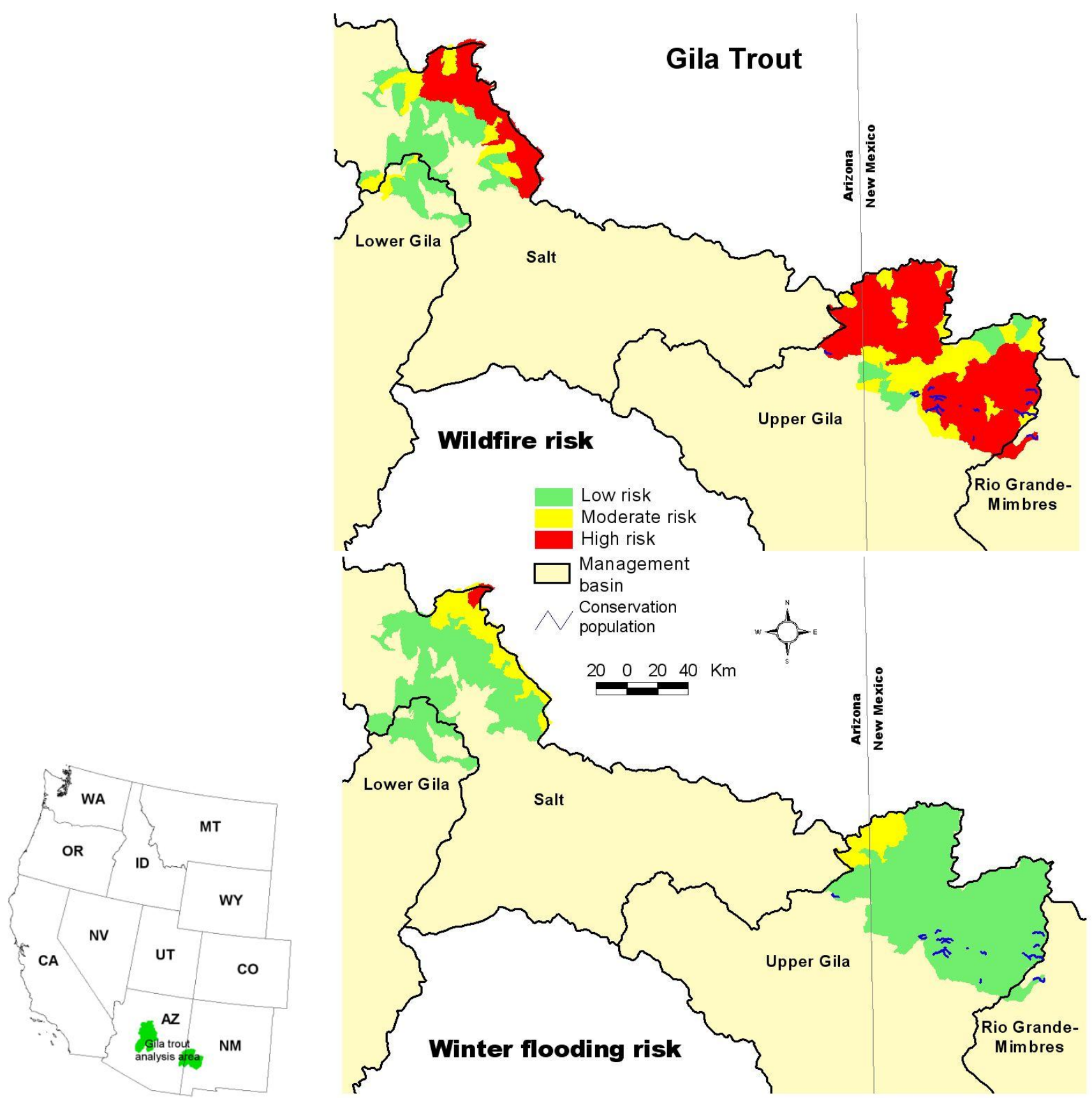

Figure 13. Risk of wildfire and winter flooding for Gila trout in their current range. 

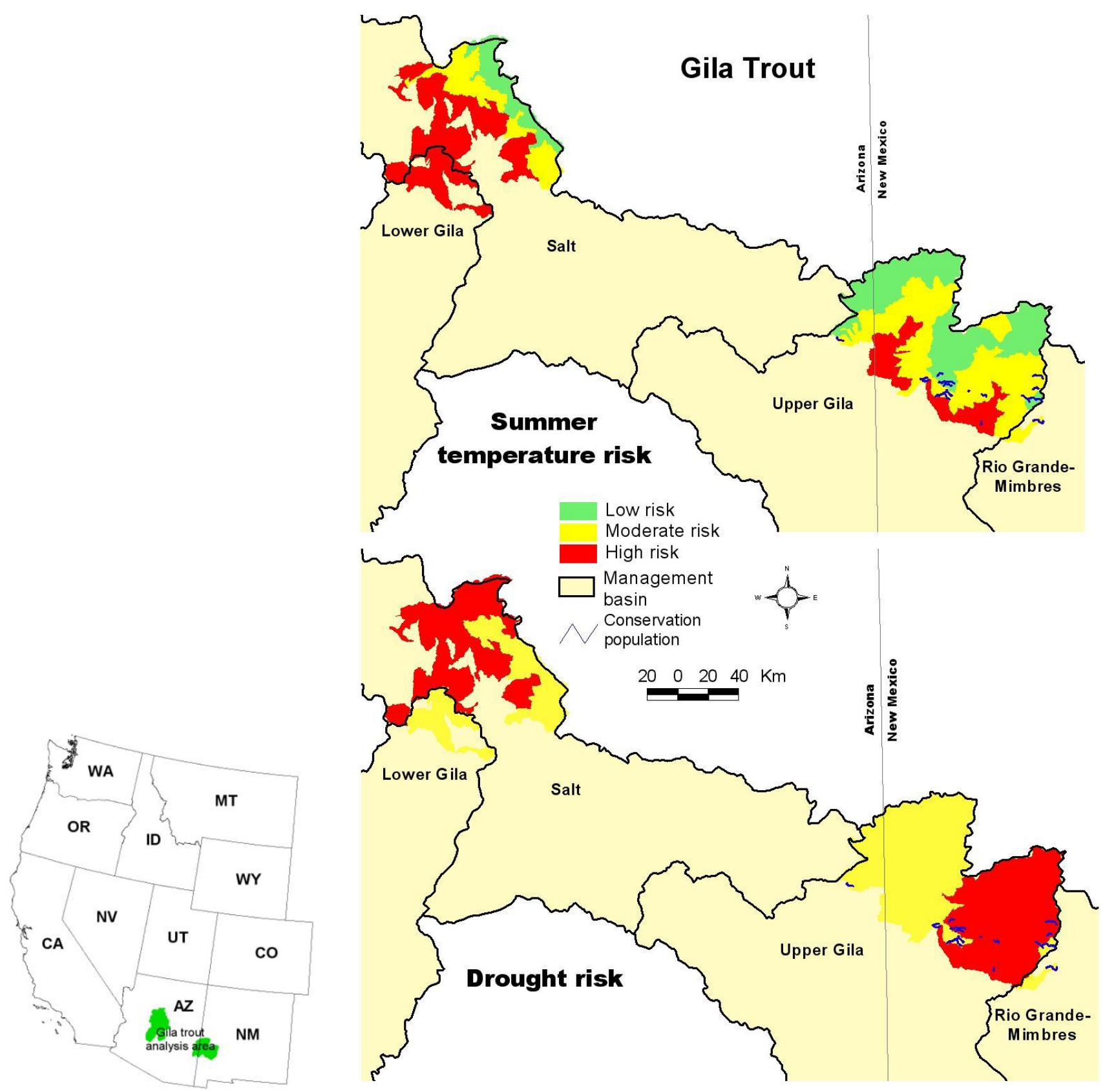

Figure 14. Risk of summer temperature increases and drought for Gila trout in their current range. 
Table 7. Ratings for increased risk from winter floods, wildfire, drought, and increased summer temperatures for subwatersheds and conservation populations of Gila trout.

\begin{tabular}{|c|c|c|c|c|c|c|c|c|c|c|c|c|c|}
\hline \multicolumn{14}{|c|}{ Currently occupied subwatersheds } \\
\hline & \multicolumn{3}{|c|}{ Flood risk } & \multicolumn{3}{|c|}{ Fire risk } & \multicolumn{3}{|c|}{ Drought risk } & \multicolumn{3}{|c|}{ Temperature risk } & $\begin{array}{c}\text { Total } \\
\text { populations }\end{array}$ \\
\hline $\begin{array}{c}\text { Management } \\
\text { basin }\end{array}$ & High & Mod & Low & High & Mod & Low & High & Mod & Low & High & Mod & Low & \\
\hline Upper Gila & 0 & 0 & 11 & 8 & 1 & 2 & 7 & 4 & 0 & 1 & 7 & 3 & 11 \\
\hline $\begin{array}{l}\text { Rio Grande-- } \\
\text { Mimbres }\end{array}$ & 0 & 0 & 1 & 1 & 0 & 0 & 0 & 1 & 0 & 0 & 1 & 0 & 1 \\
\hline \multicolumn{14}{|c|}{ Historically occupied subwatersheds } \\
\hline & \multicolumn{3}{|c|}{ Flood risk } & \multicolumn{3}{|c|}{ Fire risk } & \multicolumn{3}{|c|}{ Drought risk } & \multicolumn{3}{|c|}{ Temperature risk } & $\begin{array}{c}\text { Total } \\
\text { populations }\end{array}$ \\
\hline $\begin{array}{c}\text { Management } \\
\text { basin }\end{array}$ & High & Mod & Low & High & Mod & Low & High & Mod & Low & High & Mod & Low & \\
\hline Upper Gila & 0 & 9 & 88 & 75 & 15 & 7 & 45 & 52 & 0 & 15 & 42 & 40 & 97 \\
\hline Salt & 1 & 15 & 46 & 28 & 25 & 9 & 41 & 21 & 0 & 30 & 20 & 12 & 62 \\
\hline TOTAL & 1 & 24 & 144 & 103 & 42 & 24 & 86 & 83 & $\mathbf{0}$ & 55 & 62 & 52 & 169 \\
\hline \multicolumn{14}{|c|}{ Conservation populations } \\
\hline & \multicolumn{3}{|c|}{ Flood risk } & \multicolumn{3}{|c|}{ Fire risk } & \multicolumn{3}{|c|}{ Drought risk } & \multicolumn{3}{|c|}{ Temperature risk } & $\begin{array}{c}\text { Total } \\
\text { populations }\end{array}$ \\
\hline $\begin{array}{l}\text { Management } \\
\text { basin }\end{array}$ & High & Mod & Low & High & Mod & Low & High & Mod & Low & High & Mod & Low & \\
\hline Upper Gila & 0 & 0 & 12 & 9 & 1 & 2 & 7 & 5 & 0 & 1 & 7 & 4 & 12 \\
\hline $\begin{array}{l}\text { Rio Grande-- } \\
\text { Mimbres }\end{array}$ & 0 & 0 & 1 & 1 & 0 & 0 & 0 & 1 & 0 & 0 & 1 & 0 & 1 \\
\hline TOTAL & $\mathbf{0}$ & $\mathbf{0}$ & 13 & 10 & 1 & 2 & 7 & 6 & $\mathbf{0}$ & 1 & 8 & 4 & 13 \\
\hline
\end{tabular}


Like Apache trout, most populations of Gila trout are relatively small, occupy limited segments of streams, and fail to meet persistence criteria (table 8). Of 12 conservation populations in the upper Gila River drainage, 3 meet persistence criteria but 2 of these are rated as high risk from climate change, including primarily drought and wildfire. Of the 10 conservation populations that did not meet persistence criteria, 8 also were rated at high risk from climate change.

Table 8. Comparison of climate change risk and persistence in populations of Gila trout.

\begin{tabular}{llccc}
\hline & \multicolumn{3}{c}{ Climate change risk } \\
\hline Management basin & & High & Mod-Low & Total \\
Upper Gila & Persistent & 2 & 1 & 3 \\
& Not persistent & 7 & 2 & 9 \\
Rio Grande-Mimbres & Persistent & 0 & 0 & 0 \\
TOTAL & Not persistent & 1 & 0 & 1 \\
\hline
\end{tabular}

\section{Bonneville Cutthroat Trout}

Bonneville cutthroat trout are native to waters of the pluvial Lake Bonneville system, which consists of the Bear River Basin of Idaho, Utah, and Wyoming; the Northern Bonneville group in northern Utah; the Southern Bonneville group to the south; and the West Desert, which extends primarily along the Nevada-Utah border region. More than 90 percent of the currently occupied habitat occurs in the wetter, northeastern portions of the range in the Bear River and Northern Bonneville River basins. Bonneville cutthroat also have been introduced into the Lower Colorado-Lake Mead Basin, which consists primarily of the upper Virgin River area in southwestern Utah.

In most areas of the Bear River Basin, especially those streams around Bear Lake and streams draining the Uinta Mountains, risk is low for winter flooding and increased summer temperature (figs. 15, 16). Drought risk and wildfire risk, however, is high for most of this area. For example, 24 of 37 conservation populations (65 percent) in the Bear River drainage rate as having a high risk for wildfire, but 32 populations ( 86 percent) are rated as having a low risk for increasing summer temperature (table 9). One notable area of the Bear River Basin, the high-elevation streams draining into the Bear River from the Uinta Mountains, rate as having a low risk for all four climate change factors analyzed. 

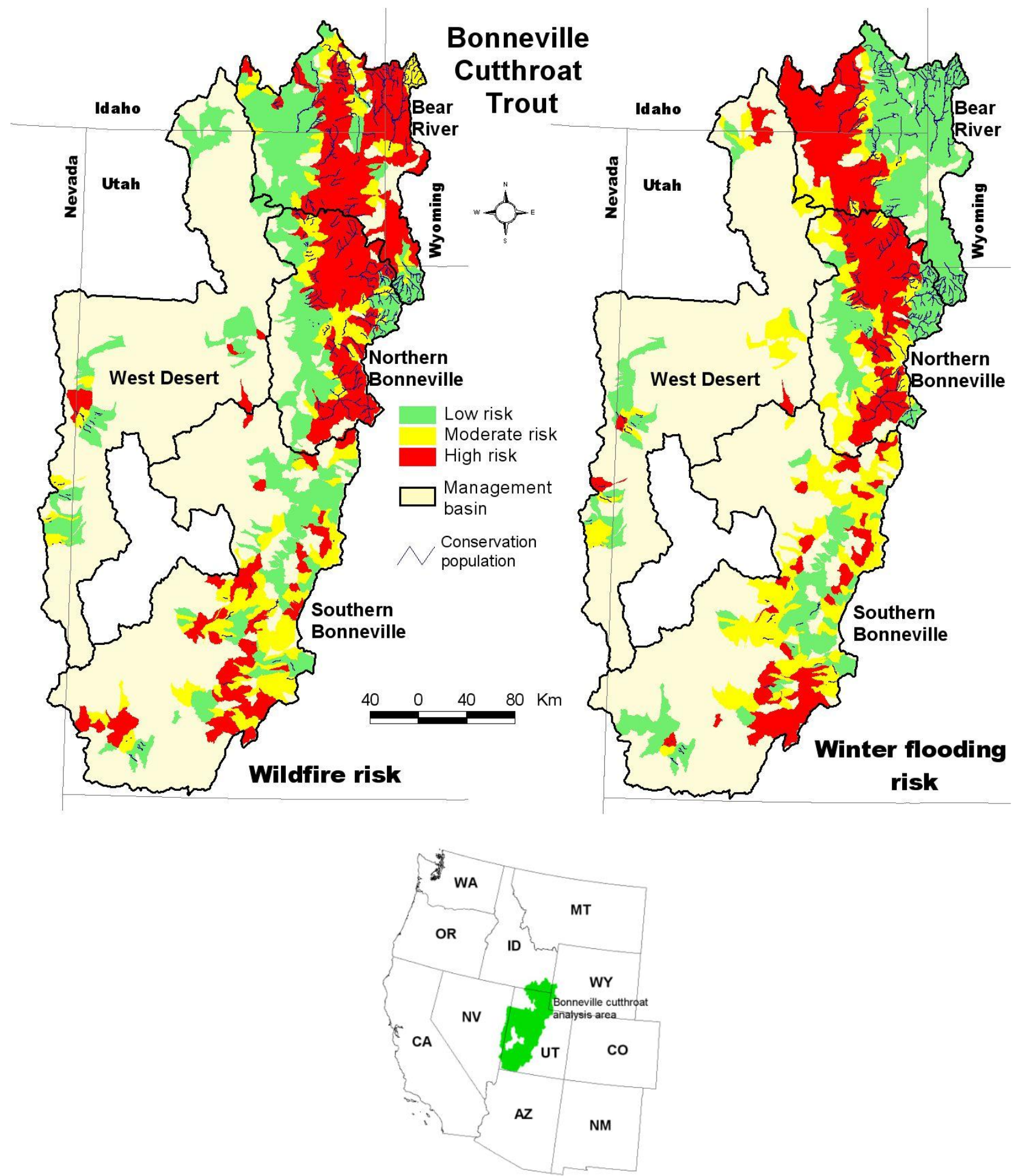

Figure 15. Risk of wildfire and winter flooding for Bonneville cutthroat trout in their current range. 

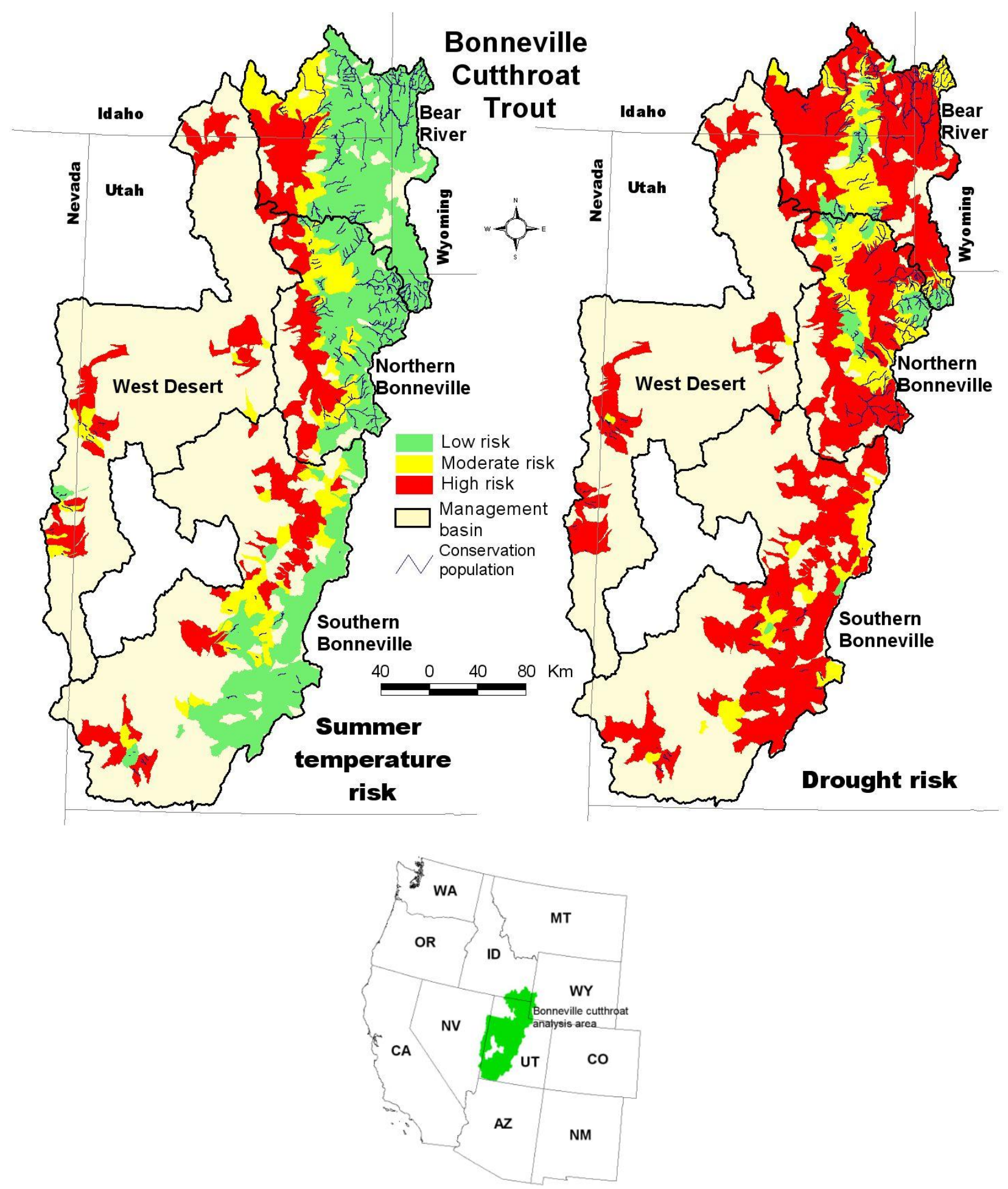

Figure 16. Risk of summer temperature increases and drought for Bonneville cutthroat trout in their current range. 
Table 9. Ratings for increased risk from winter floods, wildfire, drought, and increased summer temperatures to subwatersheds and conservation populations of Bonneville cutthroat trout.

\begin{tabular}{|c|c|c|c|c|c|c|c|c|c|c|c|c|c|}
\hline \multicolumn{14}{|c|}{ Currently occupied subwatersheds } \\
\hline \multirow[b]{2}{*}{ Management basin } & \multicolumn{3}{|c|}{ Flood risk } & \multicolumn{3}{|c|}{ Fire risk } & \multicolumn{3}{|c|}{ Drought risk } & \multicolumn{3}{|c|}{ Temperature risk } & $\begin{array}{c}\text { Total } \\
\text { populations }\end{array}$ \\
\hline & High & Mod & Low & High & Mod & Low & High & Mod & Low & High & Mod & Low & \\
\hline Bear & 15 & 8 & 62 & 61 & 11 & 13 & 44 & 28 & 13 & 2 & 7 & 76 & 85 \\
\hline Northern Bonneville & 55 & 18 & 23 & 60 & 17 & 19 & 43 & 36 & 17 & 6 & 21 & 69 & 96 \\
\hline Southern Bonneville & 3 & 12 & 6 & 6 & 7 & 8 & 17 & 4 & 0 & 3 & 6 & 12 & 21 \\
\hline West Desert & 2 & 4 & 5 & 1 & 4 & 6 & 11 & 0 & 0 & 5 & 5 & 1 & 11 \\
\hline TOTAL & 75 & 42 & 96 & 128 & 39 & 46 & 115 & 68 & 30 & 16 & 39 & 158 & 213 \\
\hline \multicolumn{14}{|c|}{ Historically occupied subwatersheds } \\
\hline & \multicolumn{3}{|c|}{ Flood risk } & \multicolumn{3}{|c|}{ Fire risk } & \multicolumn{3}{|c|}{ Drought risk } & \multicolumn{3}{|c|}{ Temperature risk } & $\begin{array}{c}\text { Total } \\
\text { populations }\end{array}$ \\
\hline Management basin & High & Mod & Low & High & Mod & Low & High & Mod & Low & High & Mod & Low & \\
\hline Bear & 61 & 15 & 93 & 90 & 24 & 55 & 109 & 44 & 16 & 27 & 27 & 115 & 169 \\
\hline Northern Bonneville & 79 & 42 & 34 & 82 & 27 & 46 & 87 & 50 & 18 & 31 & 35 & 89 & 155 \\
\hline Southern Bonneville & 51 & 92 & 49 & 58 & 68 & 66 & 160 & 30 & 2 & 48 & 35 & 109 & 192 \\
\hline West Desert & 1 & 17 & 19 & 7 & 5 & 32 & 42 & 2 & 0 & 32 & 11 & 1 & 44 \\
\hline TOTAL & 199 & 166 & 195 & 237 & 124 & 199 & 398 & 126 & 36 & 138 & 108 & 314 & 560 \\
\hline \multicolumn{14}{|c|}{ Conservation populations } \\
\hline & \multicolumn{3}{|c|}{ Flood risk } & \multicolumn{3}{|c|}{ Fire risk } & \multicolumn{3}{|c|}{ Drought risk } & \multicolumn{3}{|c|}{ Temperature risk } & $\begin{array}{c}\text { Total } \\
\text { populations }\end{array}$ \\
\hline Management basin & High & Mod & Low & High & Mod & Low & High & Mod & Low & High & Mod & Low & \\
\hline Bear & 7 & 4 & 26 & 24 & 6 & 7 & 17 & 10 & 10 & 0 & 5 & 32 & 37 \\
\hline Northern Bonneville & 44 & 17 & 12 & 47 & 15 & 11 & 24 & 30 & 19 & 4 & 19 & 50 & 73 \\
\hline Southern Bonneville & 4 & 14 & 7 & 6 & 11 & 8 & 21 & 4 & 0 & 3 & 6 & 16 & 25 \\
\hline West Desert & 7 & 11 & 11 & 1 & 12 & 16 & 29 & 0 & 0 & 14 & 11 & 4 & 29 \\
\hline TOTAL & 62 & 46 & 56 & 78 & 44 & 42 & 91 & 44 & 29 & 21 & 41 & 102 & 164 \\
\hline
\end{tabular}


In the Northern Bonneville River Basin winter flooding, wildfire, and drought are high risk factors in the majority of occupied subwatersheds. The risk of winter flooding is high in 55 of 96 (57 percent) currently occupied subwatersheds. Drought risk is high or moderate in 79 of 96 currently occupied subwatersheds in this basin (82 percent) and 54 of 73 conservation populations ( 74 percent). The elevation zone between 1,680 $\mathrm{m}$ and 2,690 $\mathrm{m}$, which covers a large part of the basin, has experienced drying and increased wildfire activity since the 1980s (Westerling and others, 2006) and, therefore, 47 of 73 conservation populations in the Northern Bonneville River Basin (64 percent) are rated as having a high risk for wildfire. Most areas were rated as having a high risk for at least two of four factors. Of conservation populations in this basin, increased summer temperature is typically a low risk factor, and 50 of 73 populations (68 percent) rated a low risk.

Climate change risk is generally higher in the more southern and western basins, where habitat occurs at lower elevations. The Southern Bonneville River Basin is highly variable in terms of wildfire and winter flooding, but rates a high risk for drought. Of the 25 conservation populations in this basin, 21 have a high risk for drought. Most conservation populations are at moderate risk from winter flooding and wildfire. Increasing summer temperature is a lower risk factor, and 16 of 25 populations (64 percent) are classified a low risk for this factor.

Small isolated populations of Bonneville cutthroat trout located in the more xeric West Desert basins along the Nevada-Utah border are at a higher risk for drought and increased summer temperature. All 29 conservation populations in the West Desert rated a high risk for drought, and 14 of these populations also were a high risk for increasing summer temperature. Introduced populations in the Lower Colorado-Lake Mead Basin also have a high risk for drought and increased summer temperature.

For the persistence analysis, 141 of 164 conservation populations were ranked at a high risk for at least one climate change factor. Of these 141 ranked at high risk, 56 (40 percent) met persistence criteria (including the majority of populations in the Bear River Basin), and 85 (60 percent) did not (table 10). About half the populations in the Northern Bonneville Basin met persistence criteria. On the other side of the continuum, only 4 of 21 populations (19 percent) in the Southern Bonneville Basin met persistence criteria. Similarly, only 2 of 29 (7 percent) populations in the West Desert Basin met persistence criteria. All of these West Desert populations also ranked at a high risk for at least one climate change risk factor. The populations exhibit a very high vulnerability in this basin, especially those from the more xeric western portions.

Table 10. Comparison of climate change risk and persistence in populations of Bonneville cutthroat trout.

\begin{tabular}{llccr}
\hline \multicolumn{4}{c}{ Climate change risk } \\
\hline Management basin & & High & Mod-Low & Total \\
Bear River & Persistent & 19 & 4 & 23 \\
Northern Bonneville & Not persistent & 10 & 4 & 14 \\
& Persistent & 31 & 4 & 35 \\
Southern Bonneville & Not persistent & 31 & 7 & 38 \\
\multirow{2}{*}{ West Desert } & Persistent & 4 & 0 & 4 \\
TOTAL & Not persistent & 17 & 4 & 21 \\
& Persistent & 2 & 0 & 2 \\
& Not persistent & 27 & 0 & 27 \\
\hline
\end{tabular}




\section{$34 \mid$ Results}

\section{Colorado River Cutthroat Trout}

Colorado River cutthroat trout are native to the Upper Colorado drainages upstream of Lee's Ferry, Arizona, including the Upper Green, Lower Green, Yampa, Upper Colorado, Lower Colorado, Dolores, Gunnison, and San Juan basins. Most remaining populations (204 of 285 conservation populations) are located in headwater streams of the Upper Green, Yampa, and Upper Colorado basins, with relatively few, fragmented populations scattered in headwater streams in the rest of the range.

Many of the conservation populations in the core areas of the Upper Green, Yampa, and Upper Colorado basins are in areas of relatively low climate change risk. Moreover, populations in these areas have a generally low risk for winter flooding and increased summer temperature, and low to moderate risk for wildfire (figs. 17, 18). Drought is likely to be the greatest climate change risk factor for these populations, and 58 of 285 conservation populations (20 percent) in these three basins ranked as having a high risk. Most populations, however, were rated as having a low to moderate drought risk (table 11). Many of these populations are located in streams draining high-elevation mountains such as the Wyoming Range, Park Range, and Uinta Mountains that are more resistant to changes in winter precipitation regimes and wildfires than are streams in lower elevation areas. Lower elevation portions of these basins are more susceptible to increased summer temperature, drought, and wildfire, but a few Colorado River cutthroat trout still occur in low-elevation streams. 

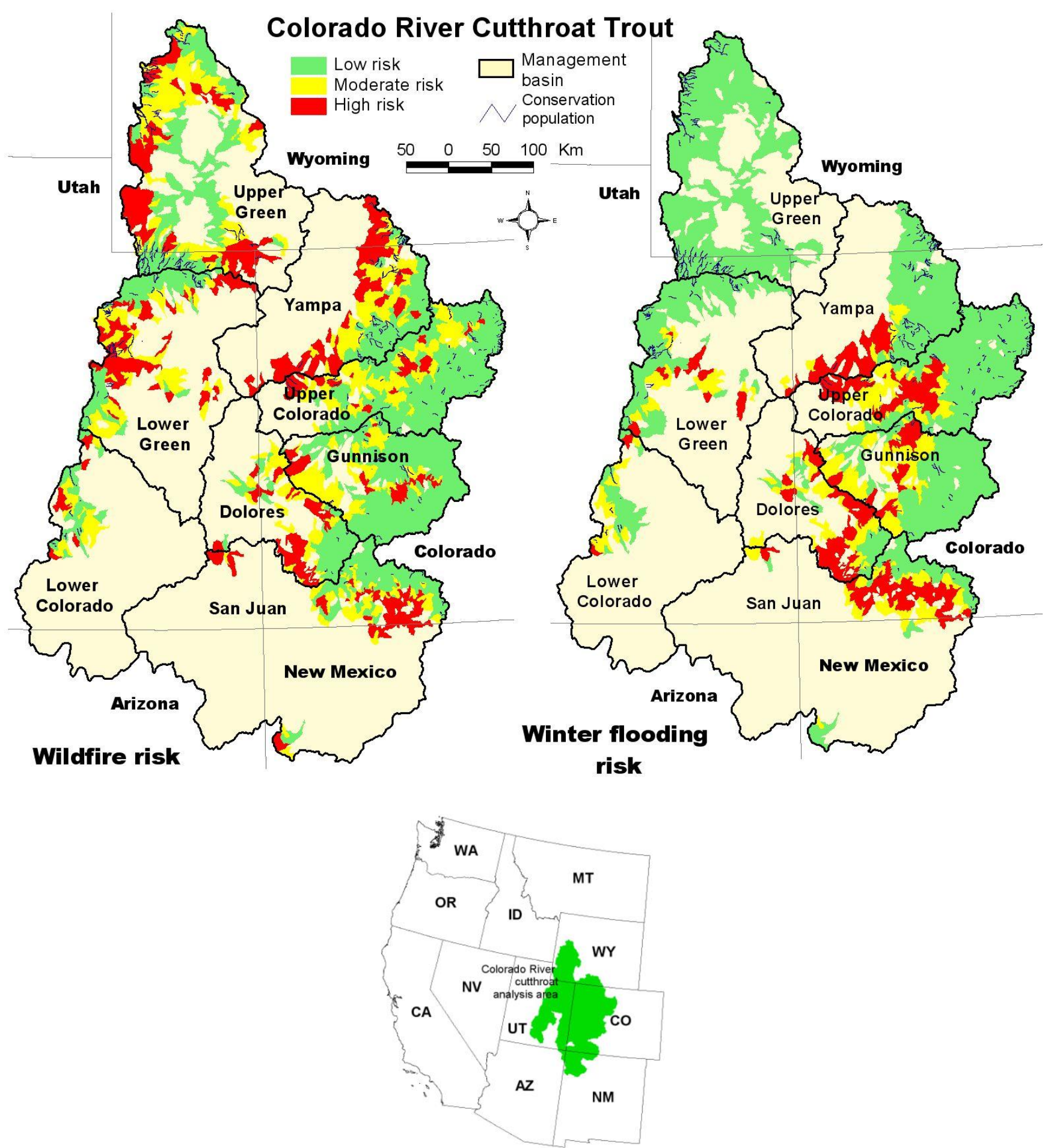

Figure 17. Risk of wildfire and winter flooding for Colorado River cutthroat trout in their current range. 

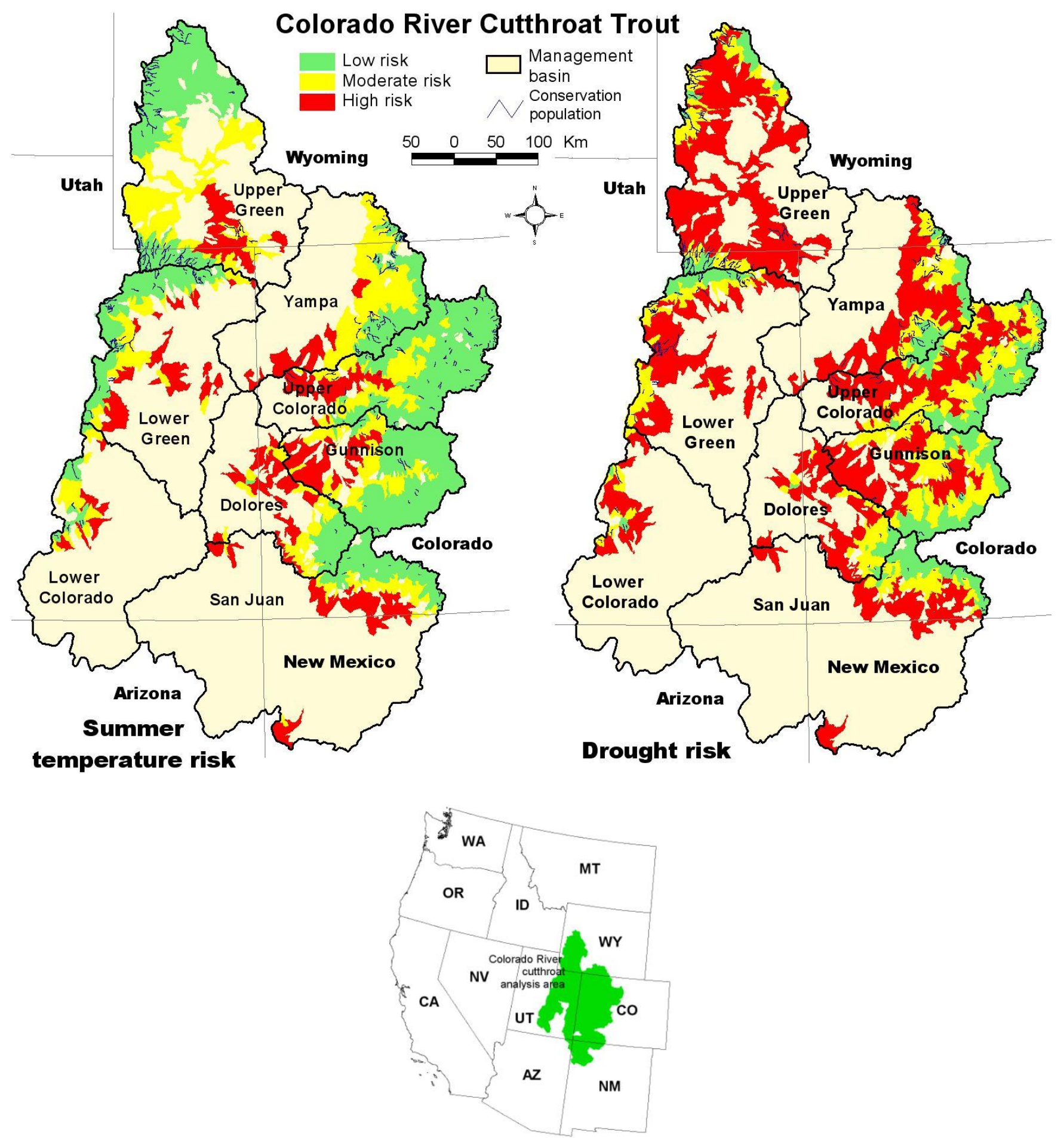

Figure 18. Risk of summer temperature increases and drought for Colorado River cutthroat trout in their current range. 
Table 11. Ratings for increased risk from winter floods, wildfire, drought, and increased summer temperatures to subwatersheds and conservation populations of Colorado River cutthroat trout.

\begin{tabular}{|c|c|c|c|c|c|c|c|c|c|c|c|c|c|}
\hline \multicolumn{14}{|c|}{ Currently occupied subwatersheds } \\
\hline & \multicolumn{3}{|c|}{ Flood risk } & \multicolumn{3}{|c|}{ Fire risk } & \multicolumn{3}{|c|}{ Drought risk } & \multicolumn{3}{|c|}{ Temperature risk } & $\begin{array}{c}\text { Total } \\
\text { populations }\end{array}$ \\
\hline $\begin{array}{c}\text { Management } \\
\text { basin }\end{array}$ & High & Mod & Low & High & Mod & Low & High & Mod & Low & High & Mod & Low & \\
\hline Dolores & 0 & 2 & 2 & 0 & 0 & 4 & 0 & 3 & 1 & 0 & 0 & 4 & 4 \\
\hline Gunnison & 3 & 6 & 8 & 0 & 4 & 13 & 4 & 11 & 2 & 0 & 7 & 10 & 17 \\
\hline $\begin{array}{l}\text { Lower } \\
\text { Colorado }\end{array}$ & 1 & 5 & 3 & 1 & 1 & 7 & 3 & 5 & 1 & 1 & 2 & 6 & 9 \\
\hline $\begin{array}{l}\text { Lower } \\
\text { Green }\end{array}$ & 2 & 3 & 27 & 10 & 7 & 15 & 16 & 11 & 5 & 2 & 7 & 23 & 32 \\
\hline San Juan & 1 & 1 & 8 & 0 & 1 & 9 & 0 & 4 & 6 & 0 & 0 & 10 & 10 \\
\hline $\begin{array}{l}\text { Upper } \\
\text { Colorado }\end{array}$ & 6 & 5 & 42 & 4 & 8 & 41 & 13 & 18 & 22 & 5 & 4 & 44 & 53 \\
\hline Upper Green & 0 & 0 & 46 & 8 & 18 & 20 & 18 & 22 & 6 & 1 & 6 & 39 & 46 \\
\hline Yampa & 1 & 2 & 39 & 10 & 11 & 21 & 9 & 21 & 12 & 1 & 17 & 24 & 42 \\
\hline TOTAL & 14 & 24 & 175 & 33 & 50 & 130 & 63 & 95 & 55 & 10 & 43 & 160 & 213 \\
\hline \multicolumn{14}{|c|}{ Historically occupied subwatersheds } \\
\hline & \multicolumn{3}{|c|}{ Flood risk } & \multicolumn{3}{|c|}{ Fire risk } & \multicolumn{3}{|c|}{ Drought risk } & \multicolumn{3}{|c|}{ Temperature risk } & $\begin{array}{c}\text { Total } \\
\text { populations }\end{array}$ \\
\hline $\begin{array}{c}\text { Management } \\
\text { basin }\end{array}$ & High & Mod & Low & High & Mod & Low & High & Mod & Low & High & Mod & Low & \\
\hline Dolores & 65 & 33 & 38 & 47 & 30 & 59 & 76 & 41 & 19 & 41 & 45 & 50 & 136 \\
\hline Gunnison & 23 & 42 & 106 & 16 & 38 & 117 & 74 & 67 & 30 & 31 & 43 & 97 & 171 \\
\hline $\begin{array}{l}\text { Lower } \\
\text { Colorado }\end{array}$ & 3 & 16 & 21 & 8 & 13 & 19 & 27 & 11 & 2 & 9 & 18 & 13 & 40 \\
\hline $\begin{array}{l}\text { Lower } \\
\text { Green }\end{array}$ & 14 & 25 & 123 & 60 & 49 & 53 & 105 & 38 & 19 & 43 & 41 & 78 & 162 \\
\hline San Juan & 91 & 54 & 73 & 62 & 49 & 107 & 100 & 56 & 62 & 62 & 54 & 102 & 218 \\
\hline $\begin{array}{l}\text { Upper } \\
\text { Colorado }\end{array}$ & 41 & 36 & 168 & 24 & 58 & 163 & 98 & 86 & 61 & 27 & 47 & 171 & 245 \\
\hline Upper Green & 0 & 0 & 218 & 58 & 68 & 92 & 166 & 37 & 15 & 29 & 75 & 114 & 218 \\
\hline Yampa & 32 & 10 & 115 & 53 & 51 & 53 & 90 & 39 & 28 & 26 & 78 & 53 & 157 \\
\hline TOTAL & 269 & 216 & 862 & 328 & 356 & 663 & 736 & 375 & 236 & 268 & 401 & 678 & 1,347 \\
\hline
\end{tabular}


Table 11. Ratings for increased risk from winter floods, wildfire, drought, and increased summer temperatures to subwatersheds and conservation populations of Colorado River cutthroat trout.-Continued

\begin{tabular}{|c|c|c|c|c|c|c|c|c|c|c|c|c|c|}
\hline \multicolumn{14}{|c|}{ Conservation populations } \\
\hline & \multicolumn{3}{|c|}{ Flood risk } & \multicolumn{3}{|c|}{ Fire risk } & \multicolumn{3}{|c|}{ Drought risk } & \multicolumn{3}{|c|}{ Temperature risk } & $\begin{array}{c}\text { Total } \\
\text { populations }\end{array}$ \\
\hline $\begin{array}{l}\text { Management } \\
\text { basin }\end{array}$ & High & Mod & Low & High & Mod & Low & High & Mod & Low & High & Mod & Low & \\
\hline Dolores & 0 & 2 & 2 & 0 & 0 & 4 & 0 & 3 & 1 & 0 & 0 & 4 & 4 \\
\hline Gunnison & 5 & 8 & 12 & 0 & 5 & 20 & 5 & 17 & 3 & 0 & 11 & 14 & 25 \\
\hline $\begin{array}{l}\text { Lower } \\
\text { Colorado }\end{array}$ & 1 & 6 & 7 & 1 & 0 & 13 & 2 & 8 & 4 & 1 & 1 & 12 & 14 \\
\hline $\begin{array}{l}\text { Lower } \\
\text { Green }\end{array}$ & 1 & 2 & 23 & 6 & 4 & 16 & 9 & 12 & 5 & 2 & 4 & 20 & 26 \\
\hline San Juan & 1 & 1 & 10 & 0 & 2 & 10 & 0 & 5 & 7 & 0 & 0 & 12 & 12 \\
\hline $\begin{array}{l}\text { Upper } \\
\text { Colorado }\end{array}$ & 5 & 6 & 64 & 3 & 10 & 62 & 14 & 24 & 37 & 5 & 4 & 66 & 75 \\
\hline Upper Green & 0 & 0 & 76 & 15 & 29 & 32 & 20 & 45 & 11 & 0 & 5 & 71 & 76 \\
\hline Yampa & 1 & 2 & 50 & 11 & 10 & 32 & 8 & 21 & 24 & 1 & 16 & 36 & 53 \\
\hline TOTAL & 14 & 27 & 244 & 36 & 60 & 189 & 58 & 135 & 92 & 9 & 41 & 235 & 285 \\
\hline
\end{tabular}


Although there are relatively few populations remaining in the Lower Colorado, Lower Green, Gunnison, Dolores, and San Juan basins, populations in these basins also tend to be located at higher elevations that are less susceptible to climate change impacts. Drought and winter flooding are the highest rated risk factors analyzed for conservation populations in these basins, particularly for populations in the Gunnison Basin. Wildfire and increasing summer temperature are typically a low risk for remaining conservation populations in the five basins. Much of the historically occupied habitats for Colorado River cutthroat trout have higher risks for all factors analyzed than currently occupied habitats, which should be considered if populations are reintroduced or reconnected in the future.

Most populations of Colorado River cutthroat trout did not meet persistence criteria because of their small population size and (or) the small amount of available habitat. Of the 74 conservation populations found to have a high risk for one or more climate change factors, 55 ( 74 percent) did not meet persistence criteria (table 12). None of the populations with high climate change risk in the Gunnison, Dolores, San Juan, or Lower Colorado basins met persistence criteria. Overall, populations in the Upper Green scored higher regarding persistence than in other basins with 26 of 76 (34 percent) meeting persistence criteria.

Table 12. Comparison of climate change risk and persistence in populations of Colorado River cutthroat trout.

\begin{tabular}{llcrr}
\hline & & & \\
\hline \multicolumn{1}{c}{ Management basin } & & Climate change risk & Mod-Low & Total \\
Upper Green & Persistent & 8 & 18 & 26 \\
Lower Green & Not persistent & 21 & 29 & 50 \\
Yampa & Persistent & 4 & 5 & 9 \\
& Not persistent & 5 & 12 & 17 \\
Upper Colorado & Persistent & 2 & 9 & 11 \\
& Not persistent & 10 & 32 & 42 \\
Gunnison & Persistent & 5 & 3 & 8 \\
Dolores & Not persistent & 9 & 58 & 67 \\
& Persistent & 0 & 1 & 1 \\
San Juan & Not persistent & 7 & 17 & 24 \\
Lower Colorado & Persistent & 0 & 0 & 0 \\
\multirow{2}{*}{ TOTAL } & Not persistent & 0 & 4 & 4 \\
& Persistent & 0 & 1 & 1 \\
& Not persistent & 1 & 10 & 11 \\
\hline
\end{tabular}




\section{Greenback Cutthroat Trout}

Greenback cutthroat trout occur in two drainages: the South Platte Basin and the Upper Arkansas Basin in Colorado. Like many native trout in the western United States, greenback cutthroat trout have been eliminated from much of the former habitat at middle and lower elevations, and most of the remaining populations occur in higher-elevation streams and lakes. Only 34 conservation populations remain: 21 in the South Platte Basin, and 13 in the Upper Arkansas Basin.

In the South Platte Basin, nearly all populations are located in high-elevation zones where climate change risks are low (figs. 19, 20). Most populations in this basin score low for three of four risk factors: increasing summer temperature, wildfire, and winter flooding. Increasing drought is the primary factor of concern in this basin, and 1 conservation population is rated as having a high risk, 9 as having a moderate risk, and 11 as having a low risk (table 13). Drought is a relatively high risk factor when examined throughout the historic range of this subspecies, with 65 percent of the historically occupied subwatersheds in the South Platte rated with a high risk. Increasing summer temperature and wildfire are also a higher risk within historic habitat in the South Platte Basin as compared to occupied habitat. 

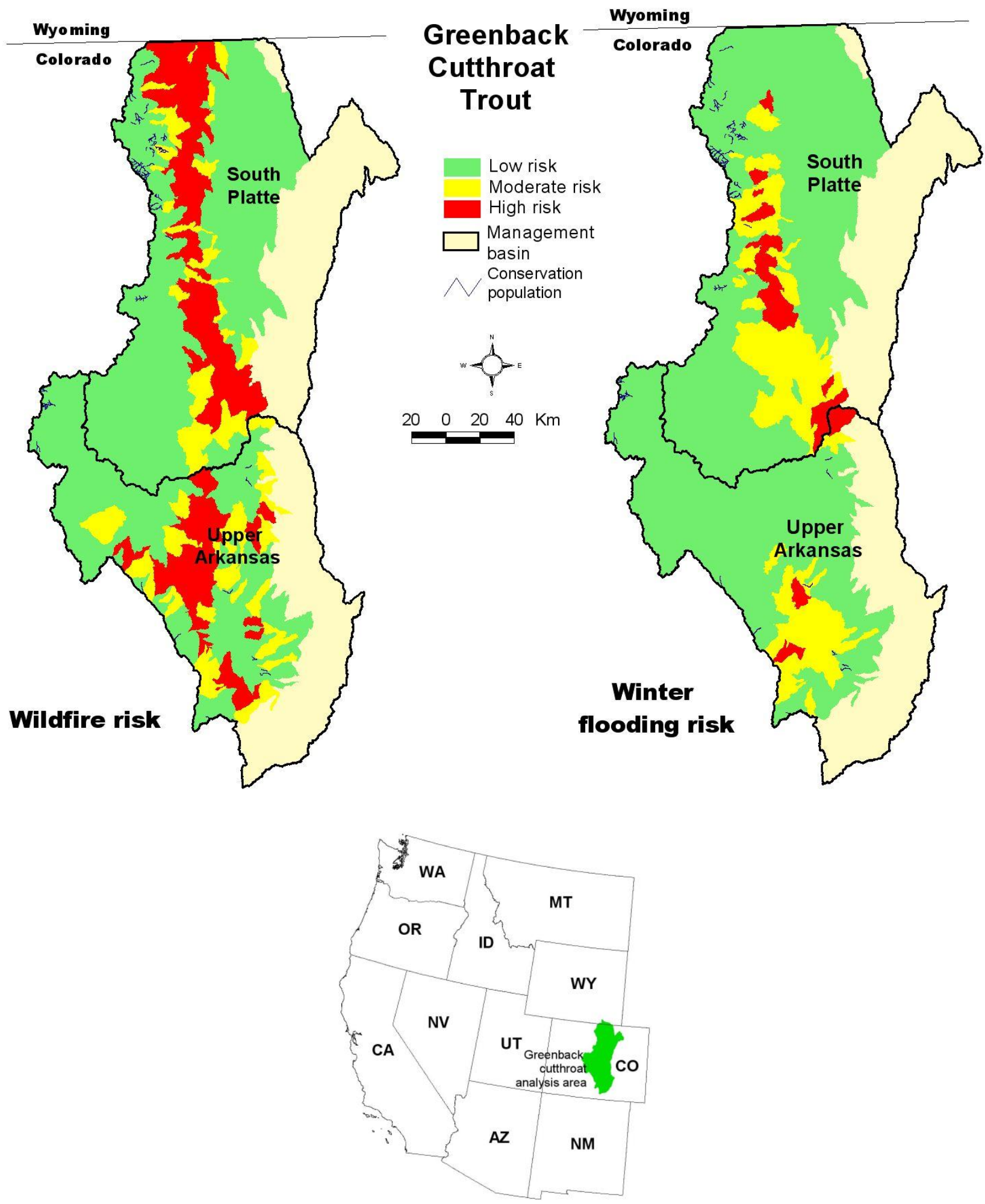

Figure 19. Risk of wildfire and winter flooding for Greenback cutthroat trout in their current range. 


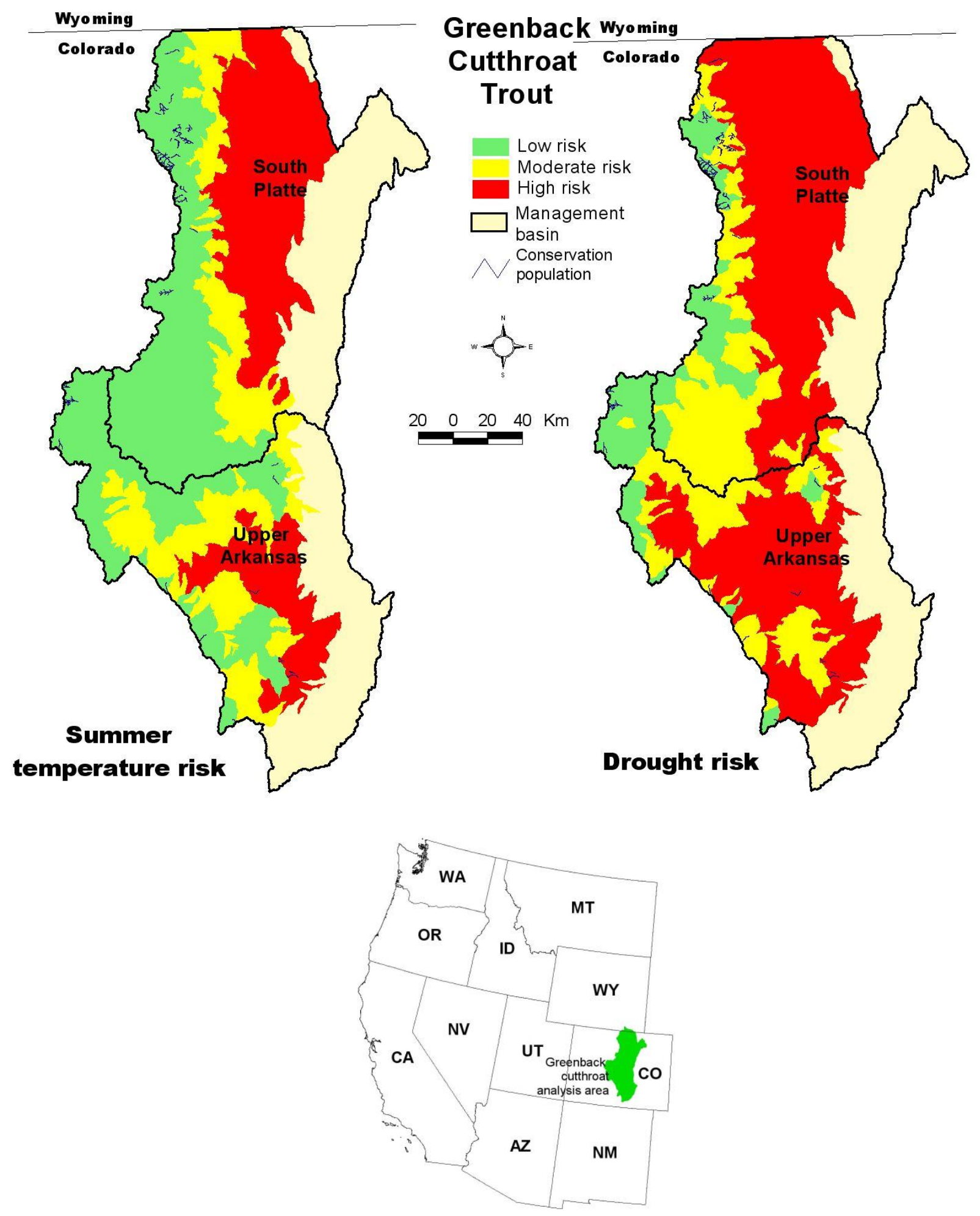

Figure 20. Risk of summer temperature increases and drought for Greenback cutthroat trout in their current range. 
Table 13. Ratings for increased risk from winter floods, wildfire, drought, and increased summer temperatures for subwatersheds and conservation populations of Greenback cuthroat trout.

\begin{tabular}{|c|c|c|c|c|c|c|c|c|c|c|c|c|c|}
\hline \multicolumn{14}{|c|}{ Currently occupied subwatersheds } \\
\hline & \multicolumn{3}{|c|}{ Flood risk } & \multicolumn{3}{|c|}{ Fire risk } & \multicolumn{3}{|c|}{ Drought risk } & \multicolumn{3}{|c|}{ Temperature risk } & $\begin{array}{c}\text { Total } \\
\text { populations }\end{array}$ \\
\hline $\begin{array}{l}\text { Management } \\
\text { basin }\end{array}$ & High & Mod & Low & High & Mod & Low & High & Mod & Low & High & Mod & Low & \\
\hline South Platte & 0 & 1 & 17 & 0 & 1 & 17 & 1 & 8 & 9 & 0 & 0 & 18 & 18 \\
\hline $\begin{array}{l}\text { Upper } \\
\text { Arkansas }\end{array}$ & 0 & 1 & 10 & 0 & 0 & 11 & 3 & 3 & 5 & 3 & 0 & 8 & 11 \\
\hline TOTAL & $\mathbf{0}$ & 2 & 27 & $\mathbf{0}$ & 1 & 28 & 4 & 11 & 14 & 3 & $\mathbf{0}$ & 26 & 30 \\
\hline \multicolumn{14}{|c|}{ Historically occupied subwatersheds } \\
\hline & \multicolumn{3}{|c|}{ Flood risk } & \multicolumn{3}{|c|}{ Fire risk } & \multicolumn{3}{|c|}{ Drought risk } & \multicolumn{3}{|c|}{ Temperature risk } & $\begin{array}{c}\text { Total } \\
\text { populations }\end{array}$ \\
\hline $\begin{array}{l}\text { Management } \\
\text { basin }\end{array}$ & High & Mod & Low & High & Mod & Low & High & Mod & Low & High & Mod & Low & \\
\hline South Platte & 25 & 54 & 202 & 71 & 36 & 174 & 184 & 67 & 30 & 105 & 58 & 118 & 281 \\
\hline $\begin{array}{l}\text { Upper } \\
\text { Arkansas }\end{array}$ & 6 & 28 & 140 & 30 & 35 & 109 & 97 & 51 & 26 & 40 & 55 & 79 & 174 \\
\hline TOTAL & 31 & 82 & 342 & 101 & 71 & 283 & 281 & 118 & 56 & 145 & 113 & 197 & 455 \\
\hline \multicolumn{14}{|c|}{ Conservation populations } \\
\hline & \multicolumn{3}{|c|}{ Flood risk } & \multicolumn{3}{|c|}{ Fire risk } & \multicolumn{3}{|c|}{ Drought risk } & \multicolumn{3}{|c|}{ Temperature risk } & $\begin{array}{c}\text { Total } \\
\text { populations }\end{array}$ \\
\hline $\begin{array}{l}\text { Management } \\
\text { basin }\end{array}$ & High & Mod & Low & High & Mod & Low & High & Mod & Low & High & Mod & Low & \\
\hline South Platte & 0 & 1 & 20 & 0 & 1 & 20 & 1 & 9 & 11 & 0 & 0 & 21 & 21 \\
\hline $\begin{array}{l}\text { Upper } \\
\text { Arkansas }\end{array}$ & 0 & 1 & 12 & 0 & 0 & 13 & 4 & 3 & 6 & 4 & 0 & 9 & 13 \\
\hline TOTAL & $\mathbf{0}$ & 2 & 32 & $\mathbf{0}$ & 1 & 33 & 5 & 12 & 17 & 4 & $\mathbf{0}$ & 30 & 34 \\
\hline
\end{tabular}


In the Upper Arkansas Basin, remaining conservation populations are located in low-risk zones for winter flooding and wildfire. According to our analysis, however, drought and increasing summer temperatures do pose risks. Four conservation populations are rated at a high risk for drought and increasing summer temperature, but most populations are rated at a low to moderate risk for these factors in the Upper Arkansas Basin. No conservation populations were rated at a high risk for winter flooding or wildfire in this basin.

Results of the persistence analysis suggested that 14 of 34 conservation populations (41 percent) met persistence criteria (table 14). Only one of the five populations that were ranked at high climate change risk met persistence criteria.

Table 14. Comparison of climate change risk and persistence in populations of Greenback cuthroat trout.

\begin{tabular}{llccc}
\hline \multicolumn{3}{c}{ Climate change risk } \\
\hline \multicolumn{1}{c}{ Management basin } & High & Mod-Low & Total \\
South Platte & Persistent & 1 & 10 & 11 \\
& Not persistent & 0 & 10 & 10 \\
Upper Arkansas & Persistent & 0 & 3 & 3 \\
TOTAL & Not persistent & 4 & 6 & 10 \\
& & $\mathbf{5}$ & $\mathbf{2 9}$ & $\mathbf{3 4}$ \\
\hline
\end{tabular}

\section{Lahontan Cutthroat Trout}

Lahontan cutthroat trout historically occurred throughout the Lahontan Basin, including the Humboldt River system in the Eastern Lahontan Basin; the Oregon closed basins and Quinn River drainage in the Northern Lahontan Basin; and the Truckee, Carson, and Walker watersheds in the Western Lahontan Basin. A total of 62 conservation populations occur within the historic range, including 29 in the Eastern Lahontan Basin. Lahontan cutthroat trout also have been introduced outside their historic range, and there are 11 conservation populations in the Sacramento, San Joaquin, Central Nevada Desert, and Great Salt Lake basins.

Drought and increasing summer temperature are the primary climate change risk factors likely to negatively affect persistence of Lahontan cutthroat trout (fig. 21). Drought risk is high or moderate for all conservation populations except for those inhabiting streams in the high-elevation Sierra Mountains in California. Drought risk is high throughout most of the Humboldt River drainage in the Eastern Lahontan Basin. Existing vegetation types and trends toward earlier commencement of summer conditions in many areas contribute to increasing wildfire risk. Increased winter flooding is a high risk factor affecting populations in the high-elevation Sierra Mountains as well as the eastern portions of the Humboldt River drainage (fig. 22). Of the 73 Lahontan Basin conservation populations, 33 (45 percent) are classified at a high risk for increased winter flooding (table 15). Although the risk of increasing summer temperature is relatively high throughout much of the historic range, the currently occupied habitat is mostly located in low-risk subwatersheds. Nearly all subwatersheds within the historic range are rated at a high risk for at least one of the four climate change factors. Conservation populations in the eastern portions of the Humboldt River drainage may be especially vulnerable because many are classified at a high risk for drought, wildfire, and winter flooding. 

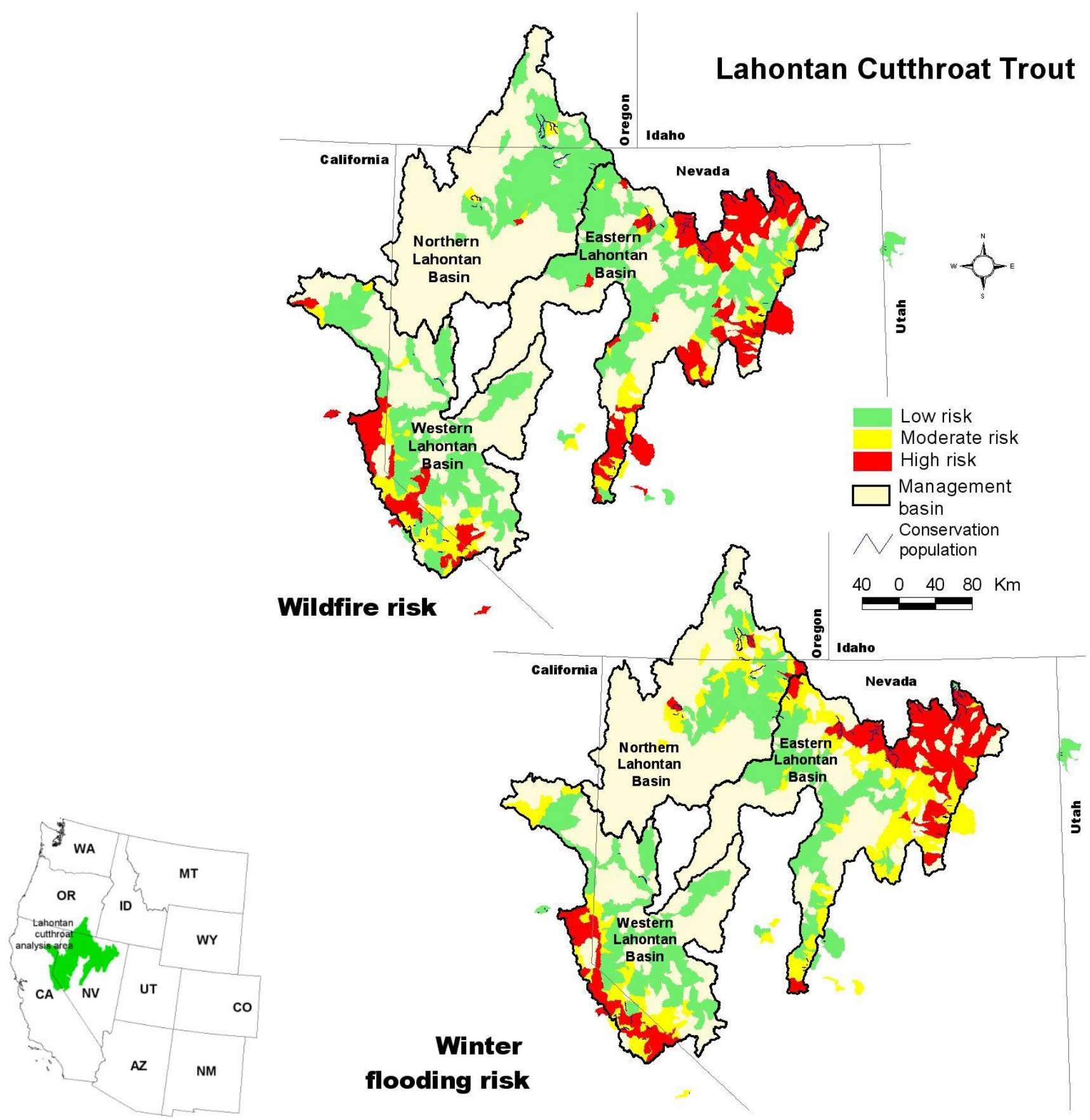

Figure 21. Risk of summer temperature increases and drought for Lahontan cutthroat trout in their current range. 

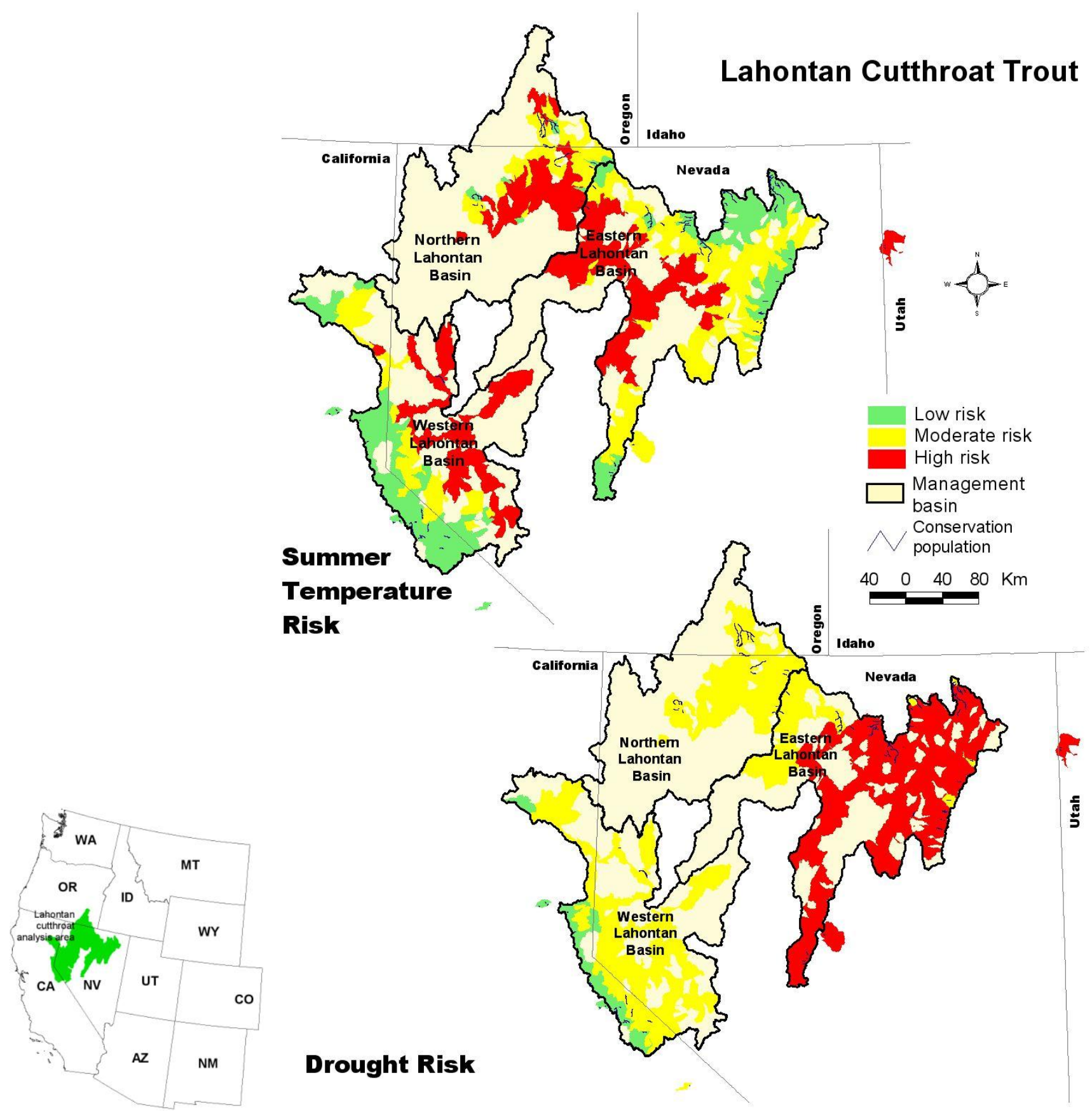

Figure 22. Risk of wildfire and winter flooding for Lahontan cutthroat trout in their current range. 
Table 15. Ratings for increased risk from winter floods, wildfire, drought, and increased summer temperatures for subwatersheds and conservation populations of Lahontan cutthroat trout.

\begin{tabular}{|c|c|c|c|c|c|c|c|c|c|c|c|c|c|}
\hline \multicolumn{14}{|c|}{ Currently occupied subwatersheds } \\
\hline & \multicolumn{3}{|c|}{ Flood risk } & \multicolumn{3}{|c|}{ Fire risk } & \multicolumn{3}{|c|}{ Drought risk } & \multicolumn{3}{|c|}{ Temperature risk } & $\begin{array}{c}\text { Total } \\
\text { populations }\end{array}$ \\
\hline $\begin{array}{c}\text { Management } \\
\text { basin }\end{array}$ & High & Mod & Low & High & Mod & Low & High & Mod & Low & High & Mod & Low & \\
\hline $\begin{array}{l}\text { Eastern } \\
\text { Lahontan }\end{array}$ & 26 & 12 & 4 & 26 & 6 & 10 & 29 & 13 & 0 & 2 & 13 & 27 & 42 \\
\hline $\begin{array}{l}\text { Northern } \\
\text { Lahontan }\end{array}$ & 2 & 8 & 3 & 0 & 3 & 10 & 0 & 13 & 0 & 2 & 9 & 2 & 13 \\
\hline $\begin{array}{l}\text { Western } \\
\text { Lahontan }\end{array}$ & 6 & 4 & 2 & 3 & 6 & 3 & 0 & 5 & 7 & 2 & 0 & 10 & 12 \\
\hline Out of basin & 1 & 1 & 4 & 4 & 0 & 2 & 3 & 1 & 2 & 2 & 1 & 3 & 6 \\
\hline TOTAL & 35 & 25 & 13 & 33 & 15 & 25 & 32 & 32 & 9 & 8 & 23 & 42 & 73 \\
\hline \multicolumn{14}{|c|}{ Historically occupied subwatersheds } \\
\hline & \multicolumn{3}{|c|}{ Flood risk } & \multicolumn{3}{|c|}{ Fire risk } & \multicolumn{3}{|c|}{ Drought risk } & \multicolumn{3}{|c|}{ Temperature risk } & $\begin{array}{c}\text { Total } \\
\text { populations }\end{array}$ \\
\hline $\begin{array}{l}\text { Management } \\
\text { basin }\end{array}$ & High & Mod & Low & High & Mod & Low & High & Mod & Low & High & Mod & Low & \\
\hline $\begin{array}{l}\text { Eastern } \\
\text { Lahontan }\end{array}$ & 101 & 95 & 51 & 93 & 46 & 108 & 199 & 48 & 0 & 51 & 121 & 75 & 247 \\
\hline $\begin{array}{l}\text { Northern } \\
\text { Lahontan }\end{array}$ & 3 & 36 & 36 & 1 & 5 & 64 & 0 & 70 & 0 & 32 & 33 & 5 & 70 \\
\hline $\begin{array}{l}\text { Western } \\
\text { Lahontan }\end{array}$ & 45 & 46 & 64 & 40 & 39 & 76 & 0 & 120 & 35 & 25 & 40 & 90 & 155 \\
\hline TOTAL & 149 & 172 & 151 & 134 & 90 & 248 & 199 & 238 & 35 & 108 & 194 & 170 & 472 \\
\hline \multicolumn{14}{|c|}{ Conservation populations } \\
\hline & \multicolumn{3}{|c|}{ Flood risk } & \multicolumn{3}{|c|}{ Fire risk } & \multicolumn{3}{|c|}{ Drought risk } & \multicolumn{3}{|c|}{ Temperature risk } & $\begin{array}{c}\text { Total } \\
\text { populations }\end{array}$ \\
\hline $\begin{array}{c}\text { Management } \\
\text { basin }\end{array}$ & High & Mod & Low & High & Mod & Low & High & Mod & Low & High & Mod & Low & \\
\hline $\begin{array}{l}\text { Eastern } \\
\text { Lahontan }\end{array}$ & 19 & 10 & 6 & 20 & 5 & 10 & 23 & 12 & 0 & 3 & 6 & 26 & 35 \\
\hline $\begin{array}{l}\text { Northern } \\
\text { Lahontan }\end{array}$ & 4 & 7 & 1 & 0 & 4 & 8 & 0 & 12 & 0 & 0 & 8 & 4 & 12 \\
\hline $\begin{array}{l}\text { Western } \\
\text { Lahontan }\end{array}$ & 7 & 7 & 1 & 3 & 10 & 2 & 0 & 5 & 10 & 1 & 0 & 14 & 15 \\
\hline Out of basin & 3 & 1 & 7 & 9 & 0 & 2 & 4 & 1 & 6 & 2 & 2 & 7 & 11 \\
\hline TOTAL & 33 & 25 & 15 & 32 & 19 & 22 & 27 & 30 & 16 & 6 & 16 & 51 & 73 \\
\hline
\end{tabular}


Most conservation populations of Lahontan cutthroat trout failed to meet persistence criteria. Of the 55 populations that were ranked at a high risk for one or more climate change risk factors, only 9 (16 percent) met persistence criteria (table 16). The Eastern Lahontan Basin contains the majority of the conservation populations, but only 6 of 35 conservation populations in that basin (17 percent) met persistence criteria, indicating that most populations occupied a relatively small habitat area and (or) had very small population sizes. In the Northern Lahontan Basin, only 3 of 12 populations met persistence criteria. Likewise, only 3 of 15 populations in the Western Lahontan Basin met persistence criteria. None of the introduced populations outside of the Lahontan system met persistence criteria.

Table 16. Comparison of climate change risk and persistence in populations of Lahontan cutthroat trout.

\begin{tabular}{llccc}
\hline \multicolumn{5}{c}{ Climate change risk } \\
\hline Management basin & & High & Mod-Low & Total \\
Eastern Lahontan & Persistent & 6 & 0 & 6 \\
\multirow{3}{*}{ Northern Lahontan } & Not persistent & 25 & 4 & 29 \\
& Persistent & 1 & 2 & 3 \\
Western Lahontan & Not persistent & 3 & 6 & 9 \\
& Persistent & 2 & 1 & 3 \\
Out of basin & Not persistent & 7 & 5 & 12 \\
\multirow{2}{*}{ TOTAL } & Persistent & 0 & 0 & 0 \\
& Not persistent & 11 & 0 & 11 \\
\hline
\end{tabular}

\section{Rio Grande Cutthroat Trout}

Historically, Rio Grande cutthroat trout occurred in the Rio Grande headwaters in Colorado; the Rio Grande, upper Canadian, and upper Pecos Rivers in New Mexico; and a few small streams in the Rio Grande drainage of Texas. This area currently provides habitat for 121 conservation populations. Our analysis follows the range-wide status assessment of Alves and others (2007), which does not include the small portions of the range in Texas where the subspecies has been extirpated (Garrett and Matlock, 1991).

Unlike other native southwestern trout, there are areas within the currently occupied range of the Rio Grande cutthroat trout where risks are scored as low or low to moderate for all four risk factors (figs. 23, 24). Of 40 conservation populations in the Rio Grande headwaters of Colorado, nearly all rank at a low risk for winter flooding, wildfire, and increasing summer temperature (table 17). Of these, 11 also rank at a low risk for drought, and the remaining 29 rank at a moderate risk for this factor. Only one conservation population in the Rio Grande Headwaters Basin occurred in a high risk area (one population scored high for winter flooding). Numerous conservation populations in the higher elevations of the Lower Rio Grande Basin also consistently rank as low risk. Many of these lower risk populations are located along the western spines of the Sangre de Cristo Mountains and Taos Mountains. Throughout the currently occupied range, increasing drought poses the most prominent risk of any of the four climate change factors with 19 conservation populations (16 percent) ranked at a high risk, 61 populations ( 50 percent) ranked at a moderate risk, and 41 populations ( 34 percent) ranked at a low risk for negative effects of drought. In general, increasing summer temperature, winter flooding, and wildfire were consistently ranked as a low risk for most conservation populations. Although climate change risk factors scored relatively low for Rio Grande cutthroat trout, risks tended to increase in severity at lower elevations and in more central and southern portions of the range where drought and, to a somewhat lesser extent, wildfire and increasing summer temperature pose problems. 


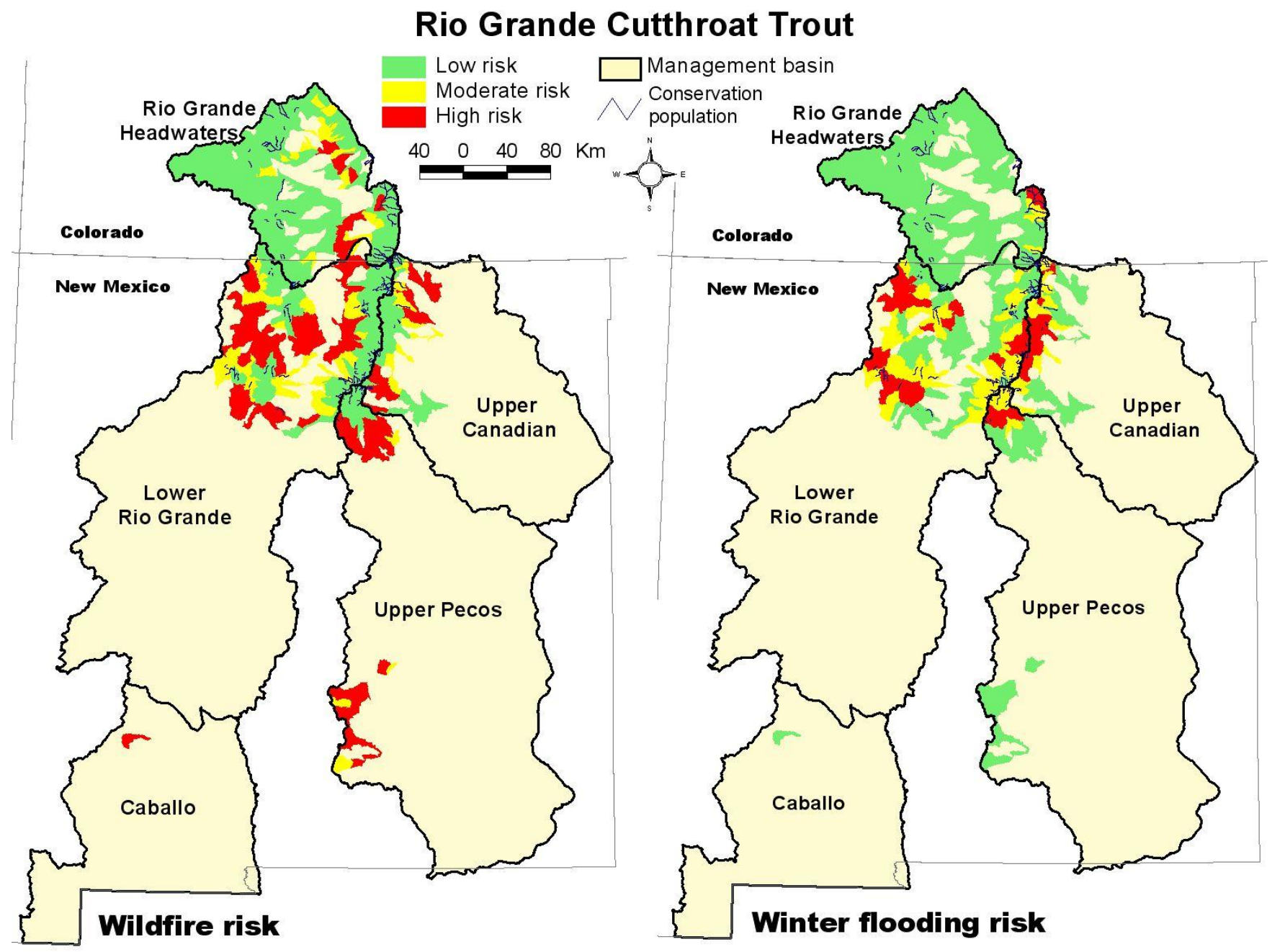

Figure 23. Risk of wildfire and winter flooding for Rio Grande cutthroat trout in their current range. 


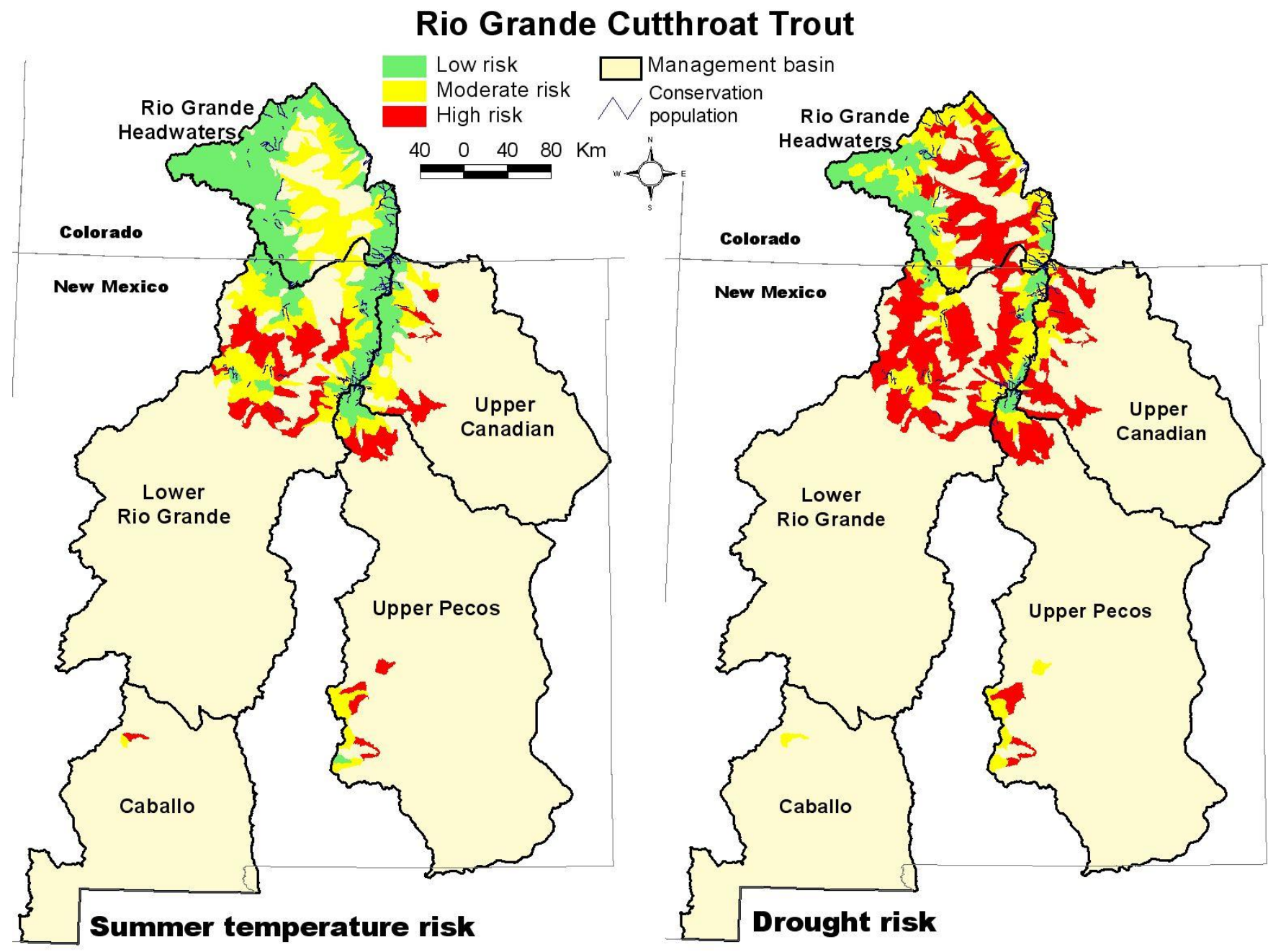

Figure 24. Risk of summer temperature increases and drought for Rio Grande cutthroat trout in their current range. 
Table 17. Ratings for increased risk from winter floods, wildfire, drought, and increased summer temperatures for subwatersheds and conservation populations of Rio Grande cutthroat trout.

\begin{tabular}{|c|c|c|c|c|c|c|c|c|c|c|c|c|c|}
\hline \multicolumn{14}{|c|}{ Currently occupied subwatersheds } \\
\hline & \multicolumn{3}{|c|}{ Flood risk } & \multicolumn{3}{|c|}{ Fire risk } & \multicolumn{3}{|c|}{ Drought risk } & \multicolumn{3}{|c|}{ Temperature risk } & $\begin{array}{c}\text { Total } \\
\text { populations }\end{array}$ \\
\hline $\begin{array}{c}\text { Management } \\
\text { basin }\end{array}$ & High & Mod & Low & High & Mod & Low & High & Mod & Low & High & Mod & Low & \\
\hline $\begin{array}{l}\text { Rio Grande } \\
\text { Headwaters }\end{array}$ & 2 & 4 & 28 & 2 & 0 & 32 & 3 & 24 & 7 & 0 & 3 & 31 & 34 \\
\hline $\begin{array}{l}\text { Lower Rio } \\
\text { Grande }\end{array}$ & 5 & 21 & 13 & 2 & 9 & 28 & 10 & 20 & 9 & 4 & 11 & 24 & 39 \\
\hline $\begin{array}{l}\text { Upper } \\
\text { Canadian }\end{array}$ & 3 & 5 & 1 & 1 & 3 & 5 & 4 & 5 & 0 & 0 & 3 & 6 & 9 \\
\hline Upper Pecos & 1 & 3 & 0 & 1 & 0 & 3 & 1 & 0 & 3 & 0 & 1 & 3 & 4 \\
\hline TOTAL & 11 & 35 & 42 & 6 & 12 & 68 & 18 & 49 & 19 & 4 & 18 & 64 & 86 \\
\hline \multicolumn{14}{|c|}{ Historically occupied subwatersheds } \\
\hline & \multicolumn{3}{|c|}{ Flood risk } & \multicolumn{3}{|c|}{ Fire risk } & \multicolumn{3}{|c|}{ Drought risk } & \multicolumn{3}{|c|}{ Temperature risk } & $\begin{array}{c}\text { Total } \\
\text { populations }\end{array}$ \\
\hline $\begin{array}{l}\text { Management } \\
\text { basin }\end{array}$ & High & Mod & Low & High & Mod & Low & High & Mod & Low & High & Mod & Low & \\
\hline $\begin{array}{l}\text { Rio Grande } \\
\text { Headwaters }\end{array}$ & 2 & 4 & 192 & 12 & 16 & 170 & 63 & 64 & 71 & 0 & 49 & 149 & 198 \\
\hline $\begin{array}{l}\text { Lower Rio } \\
\text { Grande }\end{array}$ & 29 & 48 & 60 & 54 & 31 & 52 & 86 & 37 & 14 & 42 & 56 & 39 & 137 \\
\hline Caballo & 0 & 0 & 2 & 2 & 0 & 0 & 0 & 2 & 0 & 1 & 1 & 0 & 2 \\
\hline $\begin{array}{l}\text { Upper } \\
\text { Canadian }\end{array}$ & 11 & 14 & 19 & 13 & 9 & 22 & 31 & 13 & 0 & 10 & 17 & 17 & 44 \\
\hline Upper Pecos & 5 & 5 & 29 & 26 & 5 & 8 & 21 & 15 & 3 & 15 & 16 & 8 & 39 \\
\hline TOTAL & 47 & 71 & 302 & 107 & 61 & 252 & 201 & 131 & 88 & 68 & 139 & 213 & 420 \\
\hline \multicolumn{14}{|c|}{ Conservation populations } \\
\hline & \multicolumn{3}{|c|}{ Flood risk } & \multicolumn{3}{|c|}{ Fire risk } & \multicolumn{3}{|c|}{ Drought risk } & \multicolumn{3}{|c|}{ Temperature risk } & $\begin{array}{c}\text { Total } \\
\text { populations }\end{array}$ \\
\hline $\begin{array}{l}\text { Management } \\
\text { basin }\end{array}$ & High & Mod & Low & High & Mod & Low & High & Mod & Low & High & Mod & Low & \\
\hline $\begin{array}{l}\text { Rio Grande } \\
\text { Headwaters }\end{array}$ & 1 & 3 & 36 & 0 & 0 & 40 & 0 & 29 & 11 & 0 & 0 & 40 & 40 \\
\hline $\begin{array}{l}\text { Lower Rio } \\
\text { Grande }\end{array}$ & 7 & 27 & 24 & 2 & 11 & 45 & 12 & 25 & 21 & 4 & 14 & 40 & 58 \\
\hline $\begin{array}{l}\text { Upper } \\
\text { Canadian }\end{array}$ & 4 & 7 & 1 & 2 & 3 & 7 & 5 & 7 & 0 & 0 & 4 & 8 & 12 \\
\hline Upper Pecos & 2 & 9 & 0 & 2 & 0 & 9 & 2 & 0 & 9 & 0 & 2 & 9 & 11 \\
\hline TOTAL & 14 & 46 & 61 & 6 & 14 & 101 & 19 & 61 & 41 & 4 & 20 & 97 & 121 \\
\hline
\end{tabular}


Most conservation populations of Rio Grande cutthroat trout did not meet persistence criteria because of the small population size and fragmented habitat. Of the 30 conservation populations that were rated at a high risk for one or more climate change factors, only 5 (17 percent) met persistence criteria, and 25 (83 percent) did not (table 18). Populations in the Upper Canadian Basin appeared particularly vulnerable because most rated high for climate risk and failed to meet persistence criteria. All but one population in the Upper Pecos Basin also failed to meet persistence criteria but, overall, most of these populations rated at a low or moderate climate change risk.

Table 18. Comparison of climate change risk and persistence in populations of Rio Grande cutthroat trout.

\begin{tabular}{llccc}
\hline \multicolumn{5}{c}{ Climate change risk } \\
\hline Management basin & & High & Mod-Low & Total \\
Rio Grande Headwaters & Persistent & 1 & 9 & 10 \\
& Not persistent & 0 & 30 & 30 \\
Lower Rio Grande & Persistent & 3 & 10 & 13 \\
Upper Canadian & Not persistent & 15 & 30 & 45 \\
& Persistent & 1 & 1 & 2 \\
Upper Pecos & Not persistent & 8 & 2 & 10 \\
TOTAL & Persistent & 0 & 1 & 1 \\
\hline
\end{tabular}

\section{Westslope Cutthroat Trout}

The westslope cutthroat trout has a broader range and occupies more watersheds than any of the other taxa examined. A total of 563 conservation populations are spread among 1,503 currently occupied subwatersheds (table 19). Most conservation populations occur in the expansive Clark Fork, Madison, and Upper Missouri Basins, but many large interconnected populations also occur in the Coeur D'Alene, Clearwater, and Salmon Basins. Disjunct population groups are located in the Upper Columbia Basin in Washington and the John Day Basin in Oregon.

In most basins, currently occupied habitat is at a low risk for increasing summer temperatures and moderate risk for drought, but risk of winter flooding and wildfire are more variable across basins (figs. 25, 26). Remaining conservation populations generally reflect these rankings. Throughout the entire occupied range, only 3 percent of subwatersheds were rated at a high risk for increasing summer temperature, and 2 percent were rated at a high risk for drought. For wildfire, 20 percent of occupied subwatersheds were rated at a high risk, and 23 percent rated at a high risk for winter flooding. 
Table 19. Ratings for increased risk from winter floods, wildfire, drought, and increased summer temperatures for subwatersheds and conservation populations of Westslope cutthroat trout.

\begin{tabular}{|c|c|c|c|c|c|c|c|c|c|c|c|c|c|}
\hline \multicolumn{14}{|c|}{ Currently occupied subwatersheds } \\
\hline & \multicolumn{3}{|c|}{ Flood risk } & \multicolumn{3}{|c|}{ Fire risk } & \multicolumn{3}{|c|}{ Drought risk } & \multicolumn{3}{|c|}{ Temperature risk } & \multirow[t]{2}{*}{ Total populations } \\
\hline Management basin & High & Mod & Low & High & Mod & Low & High & Mod & Low & High & Mod & Low & \\
\hline Clark Fork & 149 & 136 & 235 & 66 & 117 & 337 & 0 & 306 & 214 & 1 & 185 & 334 & 520 \\
\hline Clearwater & 88 & 76 & 42 & 14 & 42 & 150 & 0 & 35 & 171 & 15 & 92 & 99 & 206 \\
\hline Coeur D'Alene & 66 & 31 & 0 & 0 & 2 & 95 & 0 & 20 & 77 & 6 & 71 & 20 & 97 \\
\hline John Day & 7 & 17 & 4 & 0 & 5 & 23 & 0 & 28 & 0 & 3 & 24 & 1 & 28 \\
\hline Kootenai & 18 & 8 & 2 & 0 & 2 & 26 & 0 & 16 & 12 & 0 & 8 & 20 & 28 \\
\hline Madison & 0 & 2 & 117 & 85 & 30 & 4 & 0 & 115 & 4 & 0 & 15 & 104 & 119 \\
\hline Marias & 0 & 0 & 13 & 1 & 6 & 6 & 2 & 5 & 6 & 0 & 1 & 12 & 13 \\
\hline Middle Missouri & 0 & 2 & 7 & 5 & 1 & 3 & 5 & 4 & 0 & 0 & 3 & 6 & 9 \\
\hline Salmon & 8 & 80 & 314 & 116 & 188 & 98 & 0 & 286 & 116 & 18 & 88 & 296 & 402 \\
\hline Saskatchewan & 0 & 0 & 16 & 0 & 0 & 16 & 1 & 2 & 13 & 0 & 0 & 16 & 16 \\
\hline Upper Columbia & 5 & 11 & 7 & 2 & 4 & 17 & 0 & 3 & 20 & 0 & 2 & 21 & 23 \\
\hline Upper Missouri & 0 & 1 & 39 & 9 & 14 & 17 & 27 & 13 & 0 & 0 & 14 & 26 & 40 \\
\hline Musselshell & 0 & 1 & 1 & 0 & 0 & 2 & 1 & 1 & 0 & 0 & 2 & 0 & 2 \\
\hline TOTAL & 341 & 365 & 797 & 298 & 411 & 794 & 36 & 834 & 633 & 43 & 505 & 955 & $\mathbf{1 , 5 0 3}$ \\
\hline \multicolumn{14}{|c|}{ Historically occupied subwatersheds } \\
\hline & \multicolumn{3}{|c|}{ Flood risk } & \multicolumn{3}{|c|}{ Fire risk } & \multicolumn{3}{|c|}{ Drought risk } & \multicolumn{3}{|c|}{ Temperature risk } & Total populations \\
\hline Management basin & High & Mod & Low & High & Mod & Low & High & Mod & Low & High & Mod & Low & \\
\hline Clark Fork & 267 & 207 & 290 & 65 & 132 & 567 & 0 & 493 & 271 & 16 & 336 & 412 & 764 \\
\hline Clearwater & 90 & 83 & 48 & 14 & 42 & 165 & 0 & 47 & 174 & 23 & 99 & 99 & 221 \\
\hline Coeur D'Alene & 74 & 35 & 0 & 0 & 2 & 107 & 0 & 24 & 85 & 7 & 80 & 22 & 109 \\
\hline John Day & 7 & 21 & 8 & 0 & 5 & 31 & 0 & 36 & 0 & 7 & 28 & 1 & 36 \\
\hline Kootenai & 77 & 50 & 17 & 0 & 6 & 138 & 0 & 88 & 56 & 0 & 44 & 100 & 144 \\
\hline Madison & 2 & 10 & 387 & 197 & 119 & 83 & 0 & 376 & 23 & 7 & 132 & 260 & 399 \\
\hline Marias & 0 & 0 & 93 & 1 & 8 & 84 & 72 & 13 & 8 & 28 & 36 & 29 & 93 \\
\hline Middle Missouri & 1 & 6 & 70 & 6 & 5 & 66 & 70 & 7 & 0 & 18 & 45 & 14 & 77 \\
\hline Salmon & 12 & 2 & 332 & 123 & 199 & 111 & 0 & 312 & 121 & 19 & 100 & 314 & 433 \\
\hline Saskatchewan & 0 & 89 & 17 & 0 & 0 & 17 & 2 & 2 & 13 & 0 & 0 & 17 & 17 \\
\hline Upper Columbia & 19 & 35 & 7 & 1 & 4 & 56 & 0 & 3 & 58 & 10 & 12 & 39 & 61 \\
\hline Upper Missouri & 2 & 14 & 284 & 15 & 48 & 237 & 273 & 27 & 0 & 65 & 162 & 73 & 300 \\
\hline Musselshell & 0 & 2 & 2 & 0 & 0 & 4 & 3 & 1 & 0 & 1 & 3 & 0 & 4 \\
\hline TOTAL & 551 & 554 & 1,555 & 422 & 570 & 1,666 & 420 & 1,429 & 809 & 201 & 1,077 & 1,380 & 2,658 \\
\hline
\end{tabular}


Table 19. Ratings for increased risk from winter floods, wildfire, drought, and increased summer temperatures for subwatersheds and conservation populations of Westslope cutthroat trout.-Continued

\begin{tabular}{|c|c|c|c|c|c|c|c|c|c|c|c|c|c|}
\hline \multicolumn{14}{|c|}{ Conservation populations } \\
\hline & \multicolumn{3}{|c|}{ Flood risk } & \multicolumn{3}{|c|}{ Fire risk } & \multicolumn{3}{|c|}{ Drought risk } & \multicolumn{3}{|c|}{ Temperature risk } & \multirow[t]{2}{*}{ Total populations } \\
\hline Management basin & High & Mod & Low & High & Mod & Low & High & Mod & Low & High & Mod & Low & \\
\hline Clark Fork & 79 & 80 & 72 & 13 & 38 & 180 & 0 & 148 & 83 & 1 & 105 & 125 & 231 \\
\hline Clearwater & 2 & 2 & 0 & 0 & 1 & 3 & 0 & 1 & 3 & 0 & 3 & 1 & 4 \\
\hline Coeur D’Alene & 4 & 2 & 0 & 0 & 0 & 6 & 0 & 0 & 6 & 0 & 4 & 2 & 6 \\
\hline John Day & 2 & 13 & 1 & 0 & 1 & 15 & 0 & 16 & 0 & 0 & 16 & 0 & 16 \\
\hline Kootenai & 21 & 10 & 4 & 0 & 4 & 31 & 0 & 18 & 17 & 0 & 8 & 27 & 35 \\
\hline Madison & 0 & 2 & 145 & 104 & 39 & 4 & 0 & 143 & 4 & 0 & 17 & 130 & 147 \\
\hline Marias & 0 & 0 & 16 & 1 & 8 & 7 & 2 & 6 & 8 & 0 & 1 & 15 & 16 \\
\hline Middle Missouri & 0 & 3 & 6 & 4 & 1 & 4 & 5 & 4 & 0 & 0 & 4 & 5 & 9 \\
\hline Salmon & 2 & 7 & 6 & 0 & 7 & 8 & 0 & 12 & 3 & 2 & 6 & 7 & 15 \\
\hline Saskatchewan & 0 & 0 & 8 & 0 & 0 & 8 & 0 & 2 & 6 & 0 & 0 & 8 & 8 \\
\hline Upper Columbia & 2 & 11 & 4 & 1 & 4 & 12 & 0 & 1 & 16 & 0 & 1 & 16 & 17 \\
\hline Upper Missouri & 0 & 1 & 56 & 19 & 17 & 21 & 35 & 22 & 0 & 0 & 16 & 41 & 57 \\
\hline Musselshell & 0 & 1 & 1 & 0 & 0 & 2 & 1 & 1 & & 0 & 2 & 0 & 2 \\
\hline
\end{tabular}



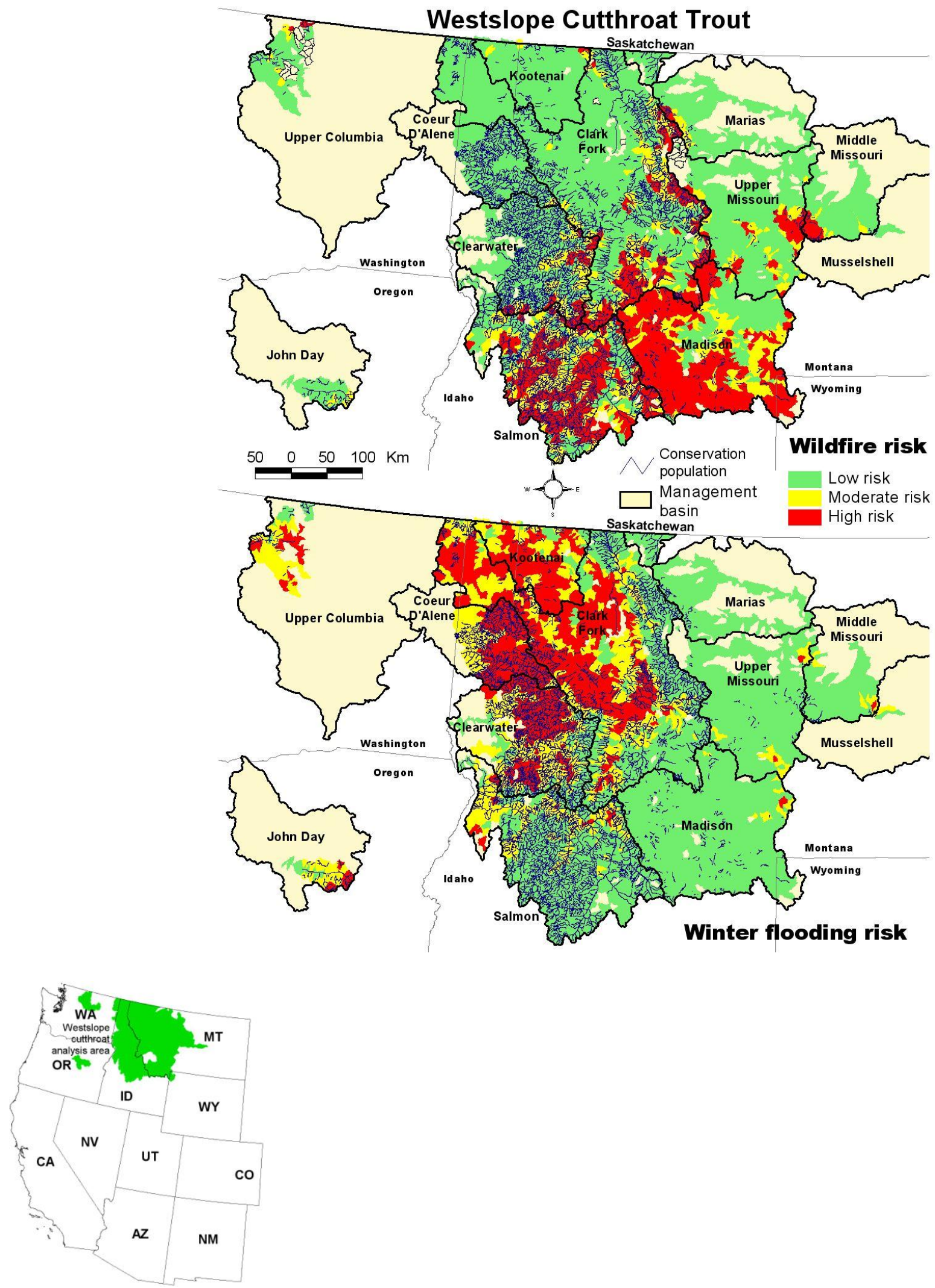

Figure 25. Risk of wildfire and winter flooding for Westslope cutthroat trout in their current range. 


\section{6 | Results}
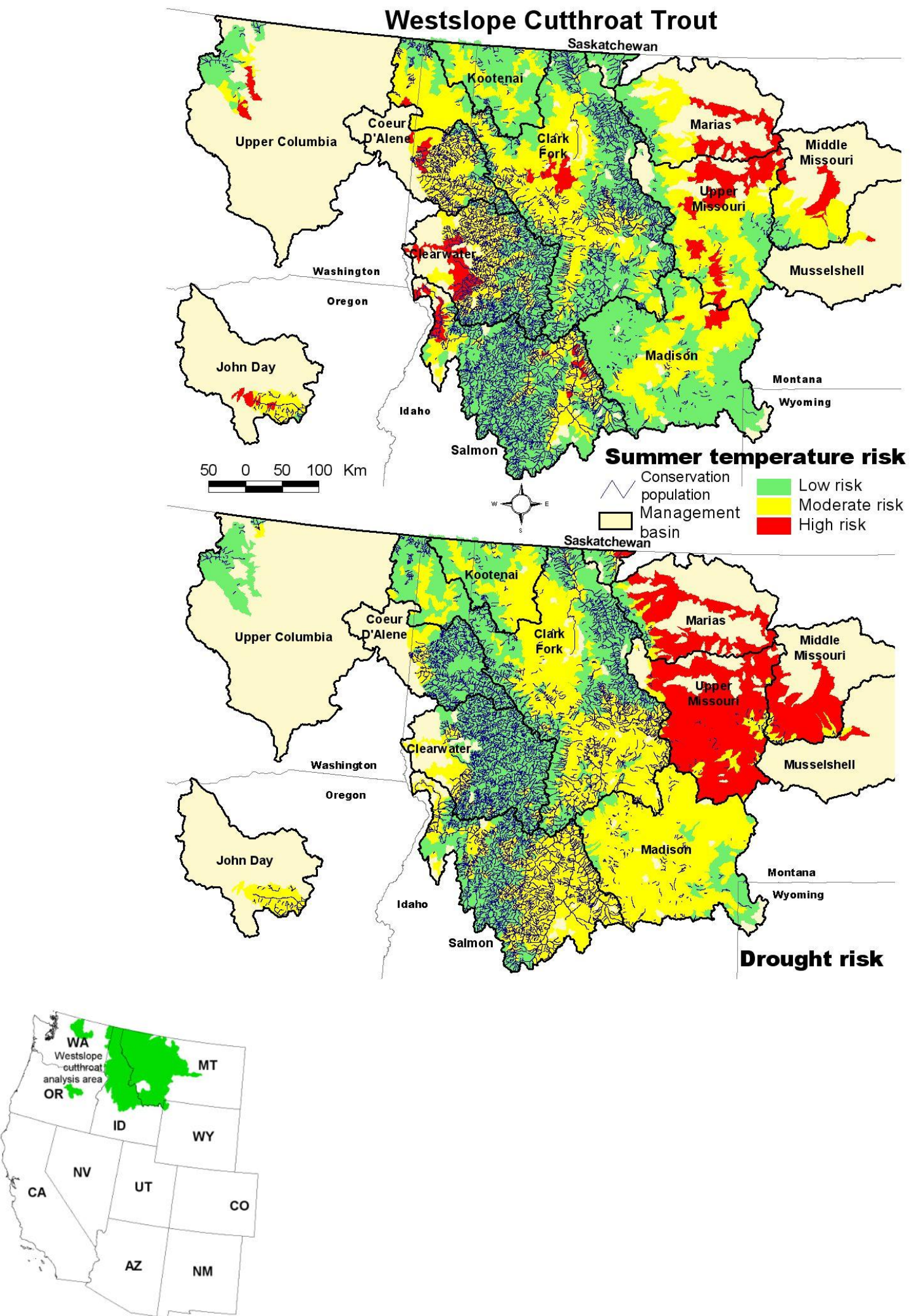

Figure 26. Risk of summer temperature increases and drought for Westslope cutthroat trout in their current range. 


\section{The Potential Influence of Changing Climate on the Persistence of Salmonids of the Inland West $\mid 57$}

In the Clark Fork Basin, summer temperature risk is low for 54 percent of the currently occupied subwatersheds, moderate for 44 percent, and high for about 2 percent. No subwatersheds in the Clark Fork Basin are at a high risk for drought, but 65 percent are at a moderate risk, and 35 percent at a low risk. Wildfire is a somewhat higher risk in the Clark Fork Basin; about 6 percent of subwatersheds are classified at a high risk, 16 percent at a moderate risk, and 78 percent at a low risk. Winter flooding is the highest risk factor in the basin, and about 34 percent of subwatersheds rated at a high risk, 35 percent at a moderate risk, and 31 percent at a low risk.

The Clearwater and Salmon Basins also have most of the currently occupied subwatersheds ranked at a low to moderate risk for increasing summer temperature and drought. Wildfire risk was somewhat higher, especially in the Salmon Basin, and 29 percent of subwatersheds ranked at a high risk, 47 percent at a moderate risk, and 24 percent at a low risk. Wildfire risk was rated as high in 7 percent of the subwatersheds of the Clearwater Basin. Risk from winter flooding also was higher, with 43 percent of subwatersheds in the Clearwater Basin at a high risk, 37 percent at a moderate risk, and 20 percent at a low risk. In the Salmon Basin, winter flooding risk is relatively low. Risk is high for 2 percent of the currently occupied subwatersheds, with a moderate risk for 20 percent and a low risk for 78 percent.

The Upper Missouri Basin is notable for having a relatively large percentage of currently occupied subwatersheds with a high risk for drought (61 percent) and wildfire (33 percent). Drought is a high risk factor throughout the Marias, Middle Missouri, and Musselshell river basins. Of the 27 occupied subwatersheds in these three basins, 8 (37 percent) are at a high risk for drought. A few conservation populations remain in the Missouri River drainages, and wildfire and drought are significant risk factors in these basins.

In the disjunct John Day Basin in Oregon, most conservation populations are rated at a moderate risk for winter flooding, drought, and increasing summer temperature, and at a low risk for wildfire. In Washington, most of the disjunct conservation populations in the Upper Columbia Basin are rated at a low risk for increasing summer temperature, drought, and wildfire, but at a moderate risk for winter flooding.

Overall, when compared to the other trout taxa examined, more conservation populations of westslope cutthroat trout met persistence criteria. Of 563 conservation populations, 216 (38 percent) met persistence criteria and 347 (62 percent) did not (table 20). Range-wide, 84 of 296 conservation populations that were rated at a high risk for one or more climate change factors (28 percent) met persistence criteria. These relatively high numbers, however, were not distributed evenly among occupied basins. Conservation populations in the Marias, Upper Missouri, and Musselshell Basins scored relatively poorly on persistence criteria. Only 4 of 16 populations (25 percent) in the Marias Basin, 4 of 57 (7 percent) in the Upper Missouri Basin, and none in the Musselshell Basin met persistence criteria, and it appears that fragmented habitat and small population sizes are more common in these basins. A majority of populations in the expansive Clark Fork Basin met persistence criteria. All populations in the well-connected stream networks of the Clearwater Basin met persistence criteria. 
Table 20. Comparison of climate change risk and persistence in populations of Westslope cuthroat trout.

\begin{tabular}{|c|c|c|c|c|}
\hline \multicolumn{5}{|c|}{ Climate change risk } \\
\hline Management basin & & High & Mod-Low & Total \\
\hline \multirow[t]{2}{*}{ Clark Fork } & Persistent & 49 & 79 & 128 \\
\hline & Not persistent & 44 & 59 & 103 \\
\hline \multirow[t]{2}{*}{ Clearwater } & Persistent & 2 & 2 & 4 \\
\hline & Not persistent & 0 & 0 & 0 \\
\hline \multirow[t]{2}{*}{ Coeur D'Alene } & Persistent & 3 & 1 & 4 \\
\hline & Not persistent & 1 & 1 & 2 \\
\hline \multirow[t]{2}{*}{ John Day } & Persistent & 2 & 5 & 7 \\
\hline & Not persistent & 0 & 9 & 9 \\
\hline \multirow[t]{2}{*}{ Kootenai } & Persistent & 5 & 8 & 13 \\
\hline & Not persistent & 16 & 6 & 22 \\
\hline \multirow[t]{2}{*}{ Madison } & Persistent & 15 & 9 & 24 \\
\hline & Not persistent & 89 & 34 & 123 \\
\hline \multirow[t]{2}{*}{ Marias } & Persistent & 0 & 4 & 4 \\
\hline & Not persistent & 3 & 9 & 12 \\
\hline \multirow[t]{2}{*}{ Middle Missouri } & Persistent & 4 & 1 & 5 \\
\hline & Not persistent & 4 & 0 & 4 \\
\hline \multirow[t]{2}{*}{ Salmon } & Persistent & 0 & 9 & 9 \\
\hline & Not persistent & 4 & 2 & 6 \\
\hline \multirow[t]{2}{*}{ Saskatchewan } & Persistent & 0 & 5 & 5 \\
\hline & Not persistent & 0 & 3 & 3 \\
\hline \multirow[t]{2}{*}{ Upper Columbia } & Persistent & 2 & 7 & 9 \\
\hline & Not persistent & 1 & 7 & 8 \\
\hline \multirow[t]{2}{*}{ Upper Missouri } & Persistent & 2 & 2 & 4 \\
\hline & Not persistent & 49 & 4 & 53 \\
\hline \multirow[t]{2}{*}{ Musselshell } & Persistent & 0 & 0 & 0 \\
\hline & Not persistent & 1 & 1 & 2 \\
\hline Total & & 296 & 267 & 563 \\
\hline
\end{tabular}

\section{Yellowstone Cutthroat Trout}

Yellowstone cutthroat trout occur in the Yellowstone, Upper Snake, and Bighorn Basins. One conservation population also occurs in the Powder-Tongue Basin. In contrast to many native trout in the western United States, Yellowstone cutthroat trout still occupy a significant portion of their historic range, including many larger, interconnected streams and large lake systems. Of 1,024 historically occupied subwatersheds, Yellowstone cutthroat trout still occur in just over 50 percent of their historic subwatersheds, a much higher percentage than many native western trout. Our analysis includes the Snake River finespotted form but focuses on stream populations rather than lakes.

For most remaining conservation populations of Yellowstone cutthroat trout, drought is the highest risk factor, followed by wildfire and winter flooding. Increasing summer temperature is a low risk for most populations (figs. 27, 28). Drought is a high risk factor for 45 percent of conservation populations in the Bighorn Basin, 35 percent of populations in the Yellowstone River Basin, 20 percent of populations in the Upper Snake River Basin, and 41 percent of populations in the Lower Snake River Basin (table 21). Wildfire is a high risk factor for 15 percent of conservation populations in the Bighorn Basin, 12 percent of populations in the Yellowstone Basin, 27 percent of populations in the Upper 

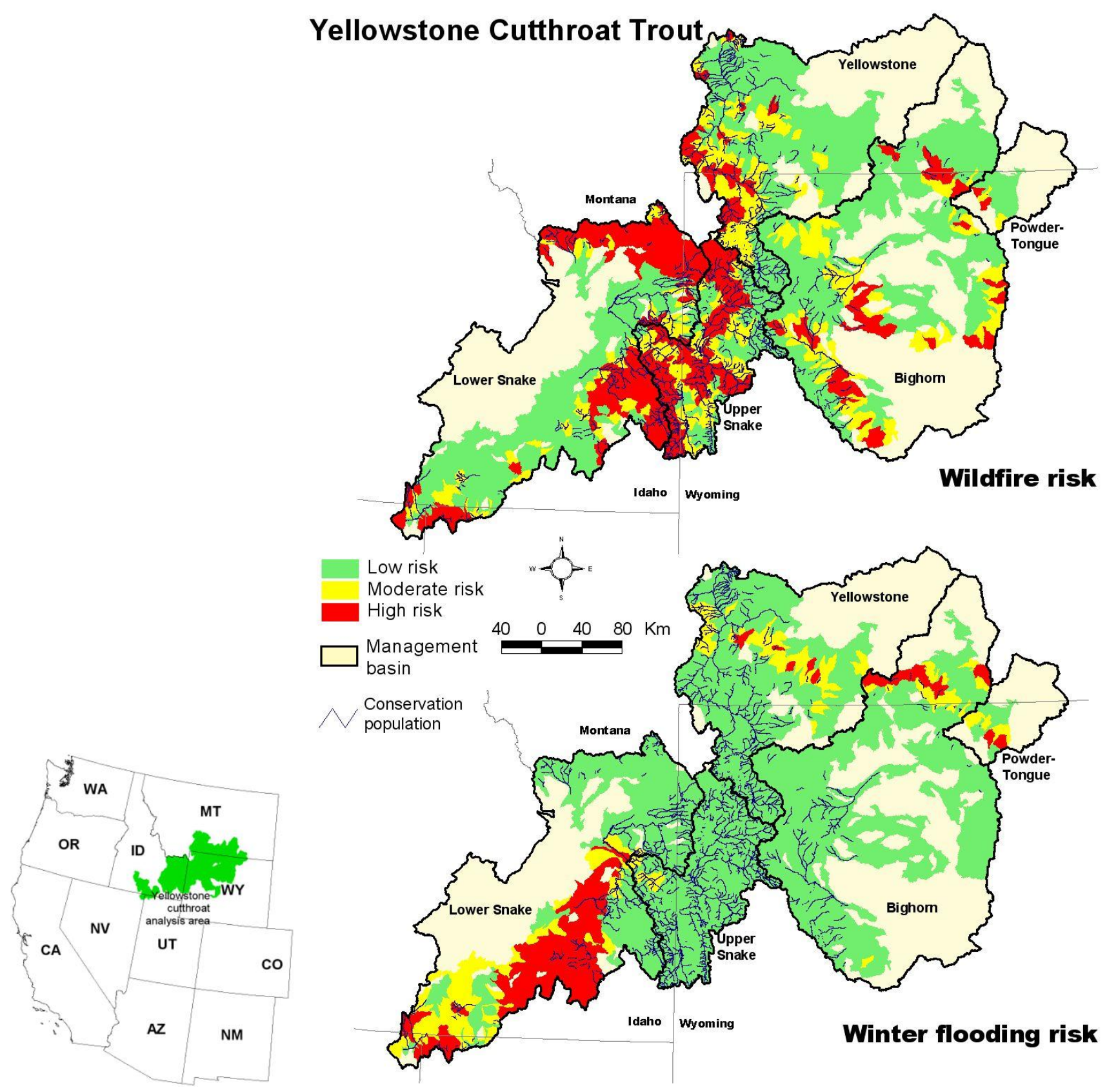

Winter flooding risk

Figure 27. Risk of wildfire and winter flooding for Yellowstone cutthroat trout in their current range. 


\section{0 | Results}

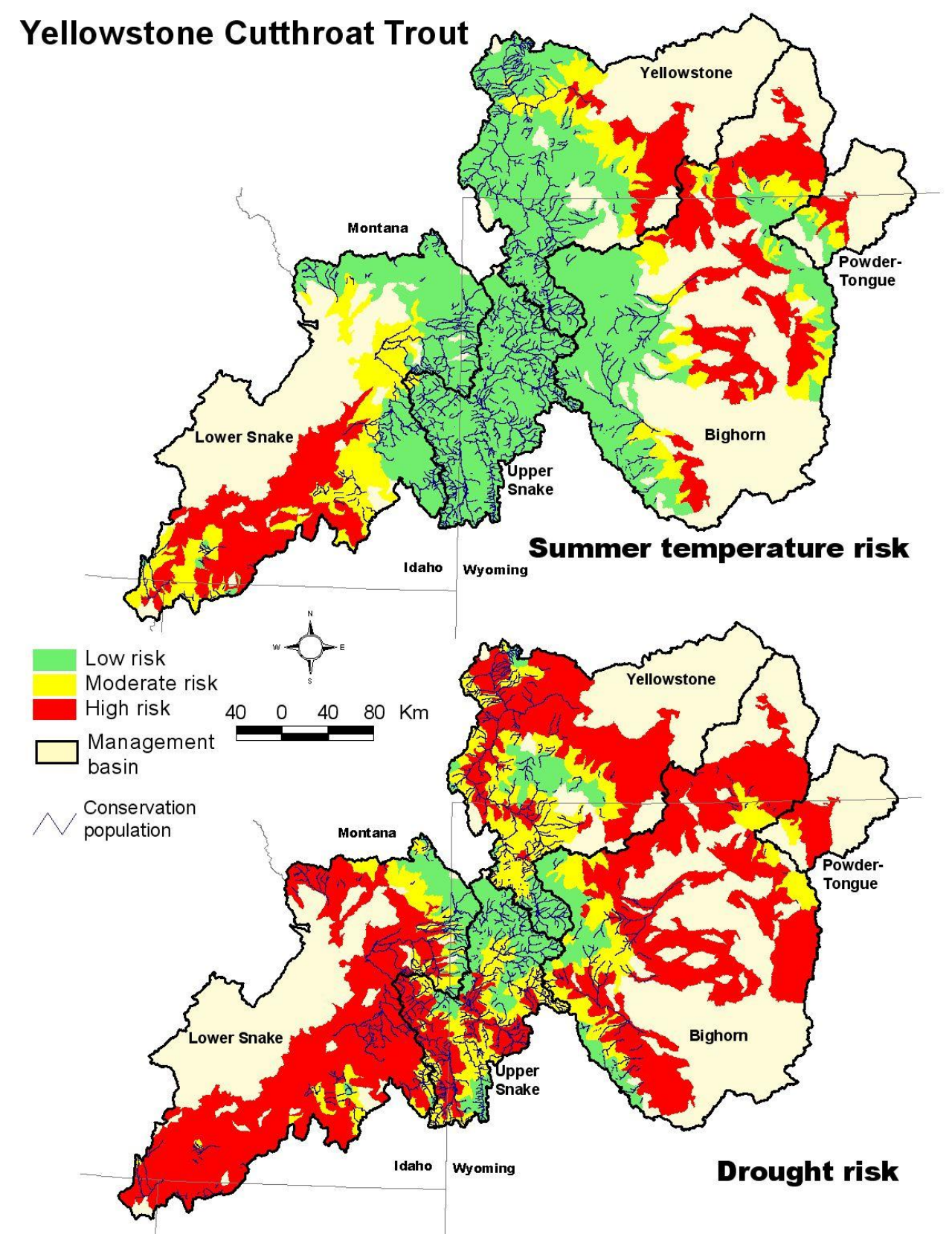

Figure 28. Risk of summer temperature increases and drought for Yellowstone cutthroat trout in their current range. 
Table 21. Ratings for increased risk from winter floods, wildfire, drought, and increased summer temperatures for subwatersheds and conservation populations of Yellowstone cutthroat trout.

\begin{tabular}{|c|c|c|c|c|c|c|c|c|c|c|c|c|c|}
\hline \multicolumn{14}{|c|}{ Currently occupied subwatersheds } \\
\hline & \multicolumn{3}{|c|}{ Flood risk } & \multicolumn{3}{|c|}{ Fire risk } & \multicolumn{3}{|c|}{ Drought risk } & \multicolumn{3}{|c|}{ Temperature risk } & $\begin{array}{c}\text { Total } \\
\text { populations }\end{array}$ \\
\hline $\begin{array}{c}\text { Management } \\
\text { basin }\end{array}$ & High & Mod & Low & High & Mod & Low & High & Mod & Low & High & Mod & Low & \\
\hline Yellowstone & 3 & 17 & 134 & 23 & 46 & 85 & 58 & 60 & 36 & 2 & 10 & 142 & 154 \\
\hline Upper Snake & 0 & 5 & 142 & 67 & 38 & 42 & 44 & 49 & 54 & 0 & 2 & 145 & 147 \\
\hline $\begin{array}{l}\text { Lower } \\
\text { Snake }\end{array}$ & 33 & 20 & 98 & 71 & 27 & 53 & 103 & 24 & 24 & 14 & 48 & 89 & 151 \\
\hline Bighorn & 3 & 4 & 90 & 18 & 23 & 56 & 49 & 30 & 18 & 3 & 11 & 83 & 97 \\
\hline $\begin{array}{l}\text { Powder- } \\
\text { Tongue }\end{array}$ & 0 & 0 & 1 & 0 & 1 & 0 & 0 & 1 & 0 & 0 & 0 & 1 & 1 \\
\hline TOTAL & 112 & 132 & 319 & 142 & 120 & 301 & 43 & 374 & 146 & 3 & 183 & 377 & 563 \\
\hline \multicolumn{14}{|c|}{ Historically occupied subwatersheds } \\
\hline & \multicolumn{3}{|c|}{ Flood risk } & \multicolumn{3}{|c|}{ Fire risk } & \multicolumn{3}{|c|}{ Drought risk } & \multicolumn{3}{|c|}{ Temperature risk } & $\begin{array}{c}\text { Total } \\
\text { populations }\end{array}$ \\
\hline $\begin{array}{l}\text { Management } \\
\text { basin }\end{array}$ & High & Mod & Low & High & Mod & Low & High & Mod & Low & High & Mod & Low & \\
\hline Yellowstone & 6 & 40 & 195 & 24 & 51 & 166 & 135 & 68 & 38 & 31 & 43 & 167 & 241 \\
\hline Upper Snake & 0 & 5 & 140 & 66 & 39 & 40 & 44 & 50 & 51 & 0 & 2 & 143 & 145 \\
\hline $\begin{array}{l}\text { Lower } \\
\text { Snake }\end{array}$ & 101 & 60 & 166 & 127 & 45 & 155 & 256 & 42 & 29 & 94 & 94 & 139 & 327 \\
\hline Bighorn & 14 & 14 & 269 & 43 & 67 & 187 & 220 & 55 & 22 & 106 & 48 & 143 & 297 \\
\hline $\begin{array}{l}\text { Powder- } \\
\text { Tongue }\end{array}$ & 2 & 5 & 7 & 2 & 2 & 10 & 11 & 3 & 0 & 5 & 4 & 5 & 14 \\
\hline TOTAL & 123 & 124 & 777 & 262 & 204 & 558 & 666 & 218 & 140 & 236 & 191 & 597 & $\mathbf{1 , 0 2 4}$ \\
\hline
\end{tabular}


Table 21. Ratings for increased risk from winter floods, wildfire, drought, and increased summer temperatures for subwatersheds and conservation populations of Yellowstone cutthroat trout.-Continued

\begin{tabular}{|c|c|c|c|c|c|c|c|c|c|c|c|c|c|}
\hline \multicolumn{14}{|c|}{ Conservation populations } \\
\hline & \multicolumn{3}{|c|}{ Flood risk } & \multicolumn{3}{|c|}{ Fire risk } & \multicolumn{3}{|c|}{ Drought risk } & \multicolumn{3}{|c|}{ Temperature risk } & $\begin{array}{c}\text { Total } \\
\text { populations }\end{array}$ \\
\hline $\begin{array}{c}\text { Management } \\
\text { basin }\end{array}$ & High & Mod & Low & High & Mod & Low & High & Mod & Low & High & Mod & Low & \\
\hline Yellowstone & 1 & 12 & 38 & 6 & 16 & 29 & 18 & 22 & 11 & 0 & 3 & 48 & 51 \\
\hline Upper Snake & 0 & 1 & 100 & 27 & 29 & 45 & 20 & 34 & 47 & 0 & 1 & 100 & 101 \\
\hline $\begin{array}{l}\text { Lower } \\
\text { Snake }\end{array}$ & 18 & 14 & 54 & 50 & 18 & 18 & 35 & 17 & 34 & 6 & 25 & 55 & 86 \\
\hline Bighorn & 4 & 6 & 57 & 10 & 8 & 49 & 30 & 18 & 19 & 2 & 8 & 57 & 67 \\
\hline $\begin{array}{l}\text { Powder- } \\
\text { Tongue }\end{array}$ & 0 & 0 & 1 & 0 & 1 & 0 & 0 & 1 & 0 & 0 & 0 & 1 & 1 \\
\hline TOTAL & 23 & 33 & 250 & 93 & 72 & 141 & 103 & 92 & 111 & 8 & 37 & 261 & 306 \\
\hline
\end{tabular}


Snake Basin, and 58 percent of populations in the Lower Snake Basin. Winter flooding is a high risk factor for 6 percent of conservation populations in the Bighorn Basin, 2 percent of populations in the Yellowstone Basin, and 21 percent of populations in the Lower Snake Basin. No populations in the Upper Snake Basin rated at a high risk for winter flooding. Increased summer temperature is rated as a high risk for only 3 percent of conservation populations in the Bighorn Basin, none in the Yellowstone Basin, none in the Upper Snake Basin, and 7 percent of populations in the Lower Snake Basin.

Compared to many subspecies of cutthroat trout, there are a relatively large number of populations that are ranked at a low risk. Many of the conservation populations in high-elevation streams around Yellowstone Lake and the headwaters of the Upper Snake River and the Wind River systems are consistently rated at a low risk for all four climate change factors examined.

A larger number of Yellowstone cutthroat trout conservation populations also met persistence criteria, but a larger proportion did not. Of 306 conservation populations, 109 (36 percent) met persistence criteria, and 197 (64 percent) did not (table 22). Similarly, 60 of 164 populations (37 percent) that were rated at a high risk for one or more climate change factors met persistence criteria, and 104 (63 percent) did not. The highest persistence ratings were in the Yellowstone Basin (the headwaters of which lie in Yellowstone National Park), where 53 percent of populations met persistence criteria.

Table 22. Comparison of climate change risk and persistence in populations of Yellowstone cutthroat trout.

\begin{tabular}{llccc}
\hline \multicolumn{5}{c}{ Climate change risk } \\
\hline Management basin & High & Mod-Low & Total \\
Yellowstone & Persistent & 8 & 19 & 27 \\
Bighorn & Not persistent & 13 & 11 & 24 \\
& Persistent & 9 & 11 & 20 \\
Powder-Tongue & Not persistent & 23 & 24 & 47 \\
& Persistent & 0 & 0 & 0 \\
Upper Snake & Not persistent & 0 & 1 & 1 \\
\multirow{2}{*}{ Lower Snake } & Persistent & 18 & 11 & 29 \\
& Not persistent & 16 & 56 & 72 \\
TOTAL & Persistent & 25 & 8 & 33 \\
& Not persistent & 52 & 1 & 53 \\
& & $\mathbf{1 6 4}$ & $\mathbf{1 4 2}$ & $\mathbf{3 0 6}$ \\
\hline
\end{tabular}

\section{Discussion}

Native trout and Arctic grayling have received widespread attention as taxa that are increasingly threatened by factors such as poor land use practices, water withdrawals, overharvest, and the introduction of nonnative species (Gresswell, 1988; Young, 1995; Behnke, 2002). These factors have contributed to the significant declines in distribution and abundance, loss of key life history characteristics, and, in some cases, the eventual extinction of individual taxa (Gresswell and others, 1994; Behnke, 2002). Added to these stressors is the emerging threat of climate change, which in many cases may accelerate or amplify existing threats and create additional stressors. As climate changes, managers will need to understand how the predicted changes may influence the conservation requirements of these species, how current stressors will change with a changing climate, and what new threats might emerge as a result. Developing new conservation strategies that incorporate this information will be the key to maintaining and restoring these subspecies.

Our analysis used a limited set of variables that have been shown to either directly or indirectly influence the quality and quantity of salmonid habitat. Although other variables related to water quality or watershed degradation may provide additional insights, we believe the variables used in this 
assessment were valuable because of their broad applicability, accessibility, and relevance to salmonid life histories. In addition, the variety of responses across the landscape provides insights into the potential drivers of salmonid persistence in the face of climate change. These geographic patterns may help us to develop adaptation strategies that can be modified to address differences among taxa.

\section{Geographic Patterns of Climate Change Risk}

All of the species and subspecies that were examined in this study have a high risk in some portion of their range for one or more of the factors analyzed. Drought is the most pervasive threat with 40 percent or more of the historic range for seven taxa at a high risk. Bonneville cutthroat trout are the most vulnerable to drought (>70 percent of the historic range at a high risk). Westslope cutthroat trout are the least likely to be affected by drought, and only 16 percent of its historically occupied subwatersheds is at a high risk. However, much of the area at a high risk lies in the Missouri River Basin where the distribution of westslope cutthroat trout has already contracted significantly and 85 percent of the remaining populations do not meet persistence criteria.

Overall, increasing summer temperature is relatively unlikely to affect the current distributions of the taxa examined. In fact, there appeared to be a significant difference in temperature risk between historic and current distributions that appears to be related to the disproportionate loss of warmer lowerelevation habitats as compared to streams at higher elevations. Only the historic habitats for Gila trout and Montana Arctic grayling had a high risk of increased summer temperature that exceeded 40 percent of the area. Given the potential synergistic effects of decreasing summer flows and rising summer temperatures, thermal conditions may be a higher risk than our analysis of independent factors indicates.

Latitude, elevation, and geographic diversity influence the vulnerability of a species or subspecies to climate change risk. Westslope cutthroat trout are at the northern extent of salmonids analyzed and have the greatest geographic distribution, incorporating a diversity of habitats and climatic regimes. They also have the lowest overall predicted risk from climate change. Nonetheless, 55 percent of the historic range of the westslope cutthroat trout is at a high risk from one or more of the factors analyzed. The cooler and wetter climate associated with the core range of the subspecies reduces the risk of drought and elevated temperature in central Idaho and northwestern Montana and, because of the relatively low elevation in the region, winter flooding is the most widespread of the risk factors analyzed.

The overall risk to Rio Grande cutthroat trout is similar to that of westslope cutthroat trout, and 56 percent of its historic habitat is at a high risk from one or more factors; however, the patterns of risk are very different. Rio Grande cutthroat trout are at the southern extent of the range of the cutthroat trout species, but the high-elevation areas where the subspecies occurs reduces the negative effects of the southern latitude and protects many of the remaining populations from the threat of wildfire, winter floods, and rising temperatures. However, the effects of persistent drought predicted for the region extends to all but the highest elevations, and reduced precipitation may exacerbate the risk of wildfire and water temperature at moderate and low elevations.

Apache trout and Gila trout are at the greatest risk of extinction- 97 percent and 94 percent of the historic ranges, respectively, have a high risk of being influenced by climate change. These fishes are found in the southwestern United States at moderate elevations. Because the current ranges of both taxa are limited, risk generally varies with elevation. At higher elevations, risk of winter flooding is high; increased temperature and drought are high risk factors for populations at lower elevations. Drainages with a large proportion of south-facing slopes are especially vulnerable to increased desiccation. Wildfire is also influenced by elevation, and high-risk areas are usually associated with moderate elevations. 


\section{The Potential Influence of Changing Climate on the Persistence of Salmonids of the Inland West}

\section{Climate Change Risk and Small Populations}

A large number of populations within the taxa examined did not meet persistence criteria, particularly in the central and southern extent of the study. Current management and restoration strategies have often focused on the occupied habitat on Federal lands or within conservation easements on private lands. Many of the target populations are small ( $<500$ individuals) and located at higher elevations above barriers to upstream movement; therefore, there is limited opportunity for large-scale movements within habitat patches or for dispersal among patches. Where conditions are limiting, populations may have little opportunity for long-term persistence (Kruse and others, 2001; Harig and Fausch, 2002; Guy and others, 2008). For example, Gila trout currently occupy mid-elevation habitat that is projected to become unsuitable during the summer if there is a projected $2{ }^{\circ} \mathrm{C}$ increase in summer water temperatures. This temperature shift could likely result in a loss of 70 percent of the suitable stream habitat in July (Kennedy and others, 2008). Coupled with an increased threat of drought and potential wildfires, small populations could face increased stochastic risk of extinction over the coming decades (Rinne, 1996; Gresswell, 1999; Kruse and others, 2001). For example, small conservation populations of Bonneville cutthroat trout were extirpated during the 2002 Sanford fire in southern Utah (J.L. Kershner, personal observation). These populations were located in small headwater streams with no connection to other tributaries.

The synergistic effects of existing stressors with increasing disturbances from climate change provide additional cause for concern for remaining isolated populations. Brown and others (2001), for example, reported how livestock grazing and fire suppression activities had combined to increase extinction risk for populations of Gila trout. Six populations of Gila trout have been eliminated in recent decades by a combination of wildfire and subsequent debris flows as rains dump ash and sediment into stream systems (Brown and others, 2001).

Projected temperature changes may also shift the zone of overlap for a number of species and may further exacerbate native and nonnative species interactions (Henderson and others, 2000). For example, native cutthroat trout in the interior West may be relegated to the highest elevation areas in the summer months to find suitable temperatures, and nonnative brown trout may occupy lower elevation habitats because of their tolerance to higher temperatures. An exception in this case may be Bonneville cutthroat trout that appear to occupy similar habitats to brown trout in larger rivers during warmer summertime periods (Colyer and others, 2005; McHugh and Budy, 2005). Where nonnative brook trout occupy similar habitats to cutthroat trout, similar shifts may occur. Brook trout appear to tolerate higher temperatures for longer time periods, suggesting a higher tolerance of warmer summer temperatures (DeStaso and Rahel, 1994).

Loss of life history expression in small populations may be the most critical factor affecting the persistence of many populations of native trout and Arctic grayling (Gresswell, 1999; Rieman and Dunham, 2000). Many of these populations have little chance to migrate to more favorable conditions for growth and reproduction in downstream habitats. Coupled with the higher risk of small population size and limited habitat, the loss of a fluvial or fluvial-adfluvial life history limits the reproduction potential of these populations as well as their ability to colonize new habitats in other areas (Rieman and others, 2003). Populations that have the ability to expand and fully express life-history attributes appear to be at a lower risk of threats associated with climate change (Gresswell, 1999). Populations that tend to be more secure from the potential effects of climate change tend to be located farther north within the Yellowstone and Westslope cutthroat trout subspecies, but exceptions exist in other subspecies where larger stream networks provide greater connectivity (Neville and others, 2006). 
In summary, small streams and associated small populations tend to be more vulnerable to environmental effects associated with climate change (Heino and others, 2009). The relationship between air temperature and water temperatures may be more strongly linked, and threats from wildfire and drought are more significant in these systems (Isaak and others, 2010). Small streams are more susceptible to low flows, and key refugia are limited during the potential rain-on-snow floods that could increase in some areas because of climate change (Guy and others, 2008). Furthermore, small streams in higher elevations may have limited potential for restoration given these conditions. Battin and others (2007) speculate that higher restoration benefits for salmon populations may occur in lower-elevation watersheds where stronger populations could help mitigate population losses at higher elevations. This type of strategy underscores the need for an expanded portfolio of conservation actions if conservation for native trout is to be successful.

\section{Importance of Peripheral Populations}

Peripheral populations, generally defined as those populations located at the geographic edge of a species or subspecies range, may have a relatively high conservation value (Scudder, 1989), but risk of extirpation may be higher for headwater populations than those located near the distributional core (Fagan, 2002; Fagan and others, 2002). Although the value of peripheral populations to the long-term survival of western trout has received little management attention, a recent evaluation of the status of peripheral and core populations in western cutthroat trout subspecies suggested that populations located at the geographic edges have declined at a much greater rate than those populations located more towards the center of distribution (Haak and others, in press). In Bonneville cutthroat trout, for example, Haak and others (in press) found that although core populations had declined by 62 percent since historic times, peripheral populations had declined by 91 percent. Many remaining peripheral populations are in small, isolated habitats with correspondingly small population sizes that render them particularly vulnerable to future habitat disturbances or invasions of nonnative species (Kruse and others, 2001; Fagan, 2002; Fagan and others, 2002).

In general, peripheral populations are considered to have increased conservation value because of their adaptation to 'marginal' habitats, their unique evolutionary history, smaller population sizes, and isolation (Scudder, 1989). These factors combine to facilitate increased genetic drift and selection pressures that result in genetic characteristics not likely to be found in larger, more stable populations (Lesica and Allendorf, 1995; Nielsen and others, 2001). Peripheral populations, therefore, maximize within-species diversity and provide the means for future adaptation to a rapidly changing environment (Scudder, 1989; Lesica and Allendorf, 1995; Hampe and Petit, 2005). Populations located on the peripheral edges of range shifts could be particularly beneficial for adaptation to higher stream temperatures. Native brook trout populations in the southern Appalachian Mountains, for instance, have a higher temperature tolerance than do brook trout populations further north near the core distribution (Flebbe and others, 2006).

The potential values and risks for peripheral populations during climate change can be illustrated with Bonneville cutthroat trout. The quality and quantity of stream habitat varies greatly among the four distinct geographic areas within the historic range of Bonneville cutthroat trout. In the West Desert portion of the historic range, stream systems are smaller and warmer during summer and more susceptible to disturbances such as drought or flood than are streams in the more mesic and denser stream drainages that characterize the Bear River, Northern Bonneville, and Southern Bonneville regions. Remaining populations in the West Desert along the Utah-Nevada border persist in isolated streams where environments are especially harsh, but these conditions are likely to become more common in the other three geographic regions in the future. Actions taken in the near-term to conserve 


\section{The Potential Influence of Changing Climate on the Persistence of Salmonids of the Inland West $\mid 67$}

peripheral populations may provide a substantial evolutionary advantage during periods of rapid environmental change that are likely to characterize the future of western trout (Haak and others, in press).

\section{Limitations of a Broad-Scale Assessment}

When interpreting our results, it is important to remember the inherent limitations of any broadscale assessment. We confined our climate analysis to a $3^{\circ} \mathrm{C}$ rise in air temperature, though there are other models that predict a range of outcomes. We believe $3^{\circ} \mathrm{C}$ represents a midpoint in the predictions that might occur, and we will be using a broader suite of climate models in a subsequent finer-scale analysis. Broad-scale studies tend to mask local conditions that could exacerbate or mitigate the regional effects of climate change, particularly evident with regard to our analysis of temperature and drought risks. The data from the Daly and others (2008) analysis assumes a spatially uniform warming trend though there are obvious local and regional differences due to elevation, topography, and local factors. The PDSI data we used as the foundation of our drought analysis was very coarse and, although we tried to refine it spatially with supplemental fine-scale data on elevation and precipitation, our results are most appropriate when interpreted at a broad scale. For example, the presence of coldwater springs could mitigate both temperature and drought, and water diversions, loss of riparian cover, and degraded wetlands may exacerbate these risks. Furthermore, our temperature analysis, by necessity, relied on air temperature rather than water temperature. Although air temperature does affect water temperature, it is not a linear relationship and our assessment of thermal risk may vary from site-specific empirical data.

The results of our flood and fire analyses should also be interpreted from a broad-scale perspective, with some additional caveats. First, our analysis did not include networked flow regimes among multiple subwatersheds, and the downstream effect of upstream winter flooding is not represented. We also did not account for any changes in precipitation quantity. In some areas of the Northwest where climate models project an increase in precipitation, we may understate the risk. Similarly, in the Southwest, where projections are for decreased precipitation, we may be exaggerating the risk of flooding. Our analysis of fire does not account for changes in condition class due to management actions, nor does it incorporate low-elevation sagebrush grasslands that now burn at a high frequency because of cheatgrass invasions, which are expected to increase as a result of climate change. Additionally, we assume that the occurrence of fire has negative consequences for all populations, but evidence suggests that, in most cases, lasting negative consequences to stream fishes caused by wildfire are generally restricted to small, isolated headwater drainages (Rinne, 1996; Dunham and others, 2007).

Climate change stressors commonly are synergistic with existing ecosystem stressors. That is, the existing integrity of stream channels, riparian habitats, and floodplains may moderate or exacerbate negative effects of climate. If habitats are degraded by existing stressors, negative consequences of climate change may be underestimated by our analysis. On the other hand, more intact watersheds where riparian areas are properly functioning and rivers have access to natural floodplains will be more resilient to disturbances associated with climate change.

In spite of these limitations, our results do provide a valuable overview of regional effects and risks to coldwater fish as a result of climate change. The broad-scale perspective can help guide managers and interested stakeholders in developing a strategic conservation framework that will increase resilience in native trout populations and improve resistance to the environmental changes brought on by a warming planet. 


\section{References}

Alves, J.E., Patten, K.A., Brauch, D.E., and P.M. Jones, 2007, Range-wide status of Rio Grande cutthroat trout (Oncorhynchus clarki virginalis): Rio Grande Cutthroat Conservation Team, 144 p.

Anderson, H.E., 1982, Aids to determining fuel models for estimating fire behavior: U.S. Forest Service General Technical Report INT-122, 22 p.

Barnett, T.P., Pierce, D.W., Hidalgo, H.G., Bonfils, C., Santer, B.D., Das, T., Bala, G., Wood, A.W., Nozawa, T., Mirin, A.A., Cayan, D.R., and Dettinger, M.D., 2008, Human-induced changes in the hydrology of the western United States: Science, v. 319, p. 1080-1083.

Bartholow, J.M., 2005, Recent water temperature trends in the Lower Klamath River, California: North American Journal of Fisheries Management, v. 25, p. 152-162.

Battin, J., Wiley, M.W., Ruckelshaus, M.H., Palmer, R.N., Korb, E., Bartz, K.K., and Imaki, H., 2007, Projected impacts of climate change on salmon habitat restoration: Proceedings of the National Academy of Sciences, v. 104, p. 6720-6725.

Behnke, R.J., 2002, Trout and salmon of North America: New York, Simon and Schuster, 359 p.

Brown, D.K., Echelle, A.A., Propst, D.L., Brooks, J.E., and Fisher, W.L., 2001, Catastrophic wildfire and number of populations as factors influencing risk of extinction for Gila trout (Oncorhynchus gilae): Western North American Naturalist, v. 61, no. 2, p. 139-148.

Brown, T.C., Hobbins, M.T., and Ramirez, J.A., 2008, Spatial distribution of water supply in the coterminous United States: Journal of the American Water Resources Association, v. 44, p. 14741487.

Carmichael, G.J., Hanson, J.N., Schmidt, M.E., and Morizot, D.C., 1993, Introgression among Apache, cutthroat, and rainbow trout in Arizona: Transactions of the American Fisheries Society, v. 122, p. $121-130$.

Climate Impacts Group, 2004, Overview of climate change impacts in the U.S. Pacific Northwest: Seattle, Wash., University of Washington, Climate Impacts Group, 13 p.

Coleman, M.A., and Fausch, K.D., 2007, Cold summer temperature limits recruitment of age-0 cutthroat trout in high-elevation Colorado streams: Transactions of the American Fisheries Society, v. 136, p. 1231-1244.

Colyer, W.T., Hilderbrand, R.H., and Kershner, J.L., 2005, Movements of fluvial Bonneville cutthroat trout in the Thomas Fork of the Bear River, Idaho-Wyoming: North American Journal of Fisheries Management, v. 25, p. 954-963.

Cox, P., and Stephenson, D., 2007, A changing climate for prediction: Science, v. 317, p. 207-208.

Daly, C., Halbleib, M., Smith, J.I., Gibson, W.P., Doggett, M.K., Taylor, G.H., Curtis, J., and Pasteris, P.A., 2008, Physiographically-sensitive mapping of temperature and precipitation across the conterminous United States: International Journal of Climatology, v. 28, p. 2031-2064, doi:10.1002/joc.1688, accessed July 28, 2009, at http://www.prism.oregonstate.edu/pub/prism/docs/ intjclim08-physiographic_mapping-daly.pdf.

De Staso, J., III, and Rahel, F.J., 1994, Influence of water temperature on interactions between young Colorado River cutthroat trout and brook trout in a laboratory stream: Transactions of the American Fisheries Society, v. 123, p. 289-297. 
Dunham, J.B., and Rieman, B.E., 1999, Metapopulation structure of bull trout-Influences of physical, biotic, and geometrical landscape characteristics: Ecological Applications, v. 9, p. 642-655.

Dunham, J.B., Rosenberger, A.E., Luce, C.H., and Rieman, B.E., 2007, Influences of wildfire and channel reorganization on spatial and temporal variation in stream temperature and the distribution of fish and amphibians: Ecosystems, v. 10, p. 335-346

Eaton, J.G., McCormick, J.H., Goodno, B.E., O’Brien, D.G., Stefany, H.G., Hondzo, M., and Scheller, R.M., 1995, A field information-based system for estimating fish temperature tolerances: Fisheries, v. 20 , no. 4 , p. $10-18$.

Fagan, W.F., 2002, Connectivity, fragmentation, and extinction risk in dendritic metapopulations: Ecology, v. 83, p. 3243-3249.

Fagan, W.F., Unmack, P.J., Burgess, C., and Minckley, W.L., 2002, Rarity, fragmentation, and extinction risk in desert fishes: Ecology, v. 83, p. 3250-3256.

Fausch, K.D., Rieman, B.E., Dunham, J.B., Young, M.K., and Peterson, D.P., 2009, Invasion versus isolation-Trade-offs in managing native salmonids with barriers to upstream movement: Conservation Biology, v. 23, p. 859-870.

Flebbe, P.A., Roghair, L.D., and Bruggink, J.L., 2006, Spatial modeling to project southern Appalachian trout distribution in a warmer climate: Transactions of the American Fisheries Society, v. 135, p. 1371-1382.

Garrett, G.P., and Matlock, G.C., 1991, Rio Grande cutthroat trout in Texas: Texas Journal of Science, v. 43, p. 406-410.

Gresswell, R.E., ed., 1988, Status and management of interior stocks of cutthroat trout: Bethesda, Md., American Fisheries Society, Proceedings of Symposium 4, 140 p.

Gresswell, R.E., 1999, Fire and aquatic ecosystems in forested biomes of North America: Transactions of the American Fisheries Society, v. 128, p. 193-221.

Gresswell, R.E., Liss, W.J., and Larson, G.L., 1994, Life-history organization of Yellowstone cutthroat trout (Oncorhynchus clarki bouvieri) in Yellowstone Lake: Canadian Journal of Fisheries and Aquatic Sciences, v. 51, Supplement 1, p. 298-309.

Guy, T.J., Gresswell, R.E., and Banks, M.A., 2008, Landscape-scale evaluation of genetic structure among barrier-isolated populations of coastal cutthroat trout, Oncorhynchus clarkii clarkii: Canadian Journal of Fisheries and Aquatic Sciences, v. 65, p. 1749-1762.

Haak, A.L., Williams, J.E., Neville, H.M., Dauwalter, D.C., and Colyer, W.T., in press, Conserving peripheral trout populations-The value and risk of life on the edge: Fisheries, v. 35.

Hamlet, A.F., and Lettenmaier, D.P., 2005, Production of temporally consistent gridded precipitation and temperature fields for the continental United States: Journal of Hydrometeorology, v. 6, p. 330-336.

Hampe, A., and Petit, R.J., 2005, Conserving biodiversity under climate change-The rear edge matters: Ecology Letters, v. 8, p. 461-467.

Hari, R.E., Livingstone, D.M., Siber, R., Burkhardt-Holm, P., and Guttinger, H., 2006, Consequences of climate change for water temperature and brown trout populations in alpine rivers and streams: Global Change Biology, v. 12, p. 10-26. 
Harig, A.L., and Fausch, K.D., 2002, Minimum habitat requirements for establishing translocated cutthroat trout populations: Ecological Applications, v. 12, p. 535-551.

Heino, J., Virkkala, R., and Toivonen, H., 2009, Climate change and freshwater biodiversity-Detected patterns, future trends, and adaptations in northern regions: Biological Reviews, v. 84, p. 39-54.

Henderson, R., Kershner, J.L., and Toline, C.A., 2000, Timing and location of spawning by nonnative wild rainbow trout and native cutthroat trout in the South Fork Snake River, Idaho, with implications: North American Journal of Fisheries Management, v. 20, p. 584-596.

Hilderbrand, R.H., and Kershner, J.L., 2000, Conserving inland cutthroat trout in small streams-How much stream is enough?: North American Journal of Fisheries Management, v. 20, p. 513-520.

Hirsch, C.L., Albeke, S.E., and Nesler, T.P., 2006, Range-wide status of Colorado River cutthroat trout (Oncorhynchus clarkii pleuriticus) -2005: Denver, Colo., Colorado Division of Wildlife, Information taken from http://wildlife.state.co.us/NR/rdonlyres/FB21A867-6985-4D11-B205-

573D8C6F5407/0/FINAL_CRCTStatusReview_04042006.pdf.

Hoerling, M., and Eischeid, J., 2007, Past peak water in the Southwest: Southwest Hydrology, Information taken from http://www.swhydro.arizona.edu/archive/V6_N1/. 18-35.

Intergovernmental Panel on Climate Change, 2007, Climate change 2007-The physical science basis. Contribution of Working Group I to the Fourth Assessment Report of the Intergovernmental Panel on Climate Change: New York and Cambridge, U.K., Cambridge University Press, Information taken from http://www.ipcc.ch/pdf/assessment-report/ar4/wg1/ar4-wg1-frontmatter.pdf.

Isaak, D.J., Luce, C., Rieman, B.E., Nagel, D., Peterson, E., Horan, D., Parkes, S., and Chandler, G., 2010, Effects of climate change and wildfire on stream temperatures and salmonid thermal habitat in a mountain river network: Ecological Applications, v. 20, p. 1350-1371.

Jager, H.I., Van Winkle, W., and Holcomb, B.D., 1999, Would hydrologic climate changes in Sierra Nevada streams influence trout persistence?: Transactions of the American Fisheries Society, v. 128, p. 222-240.

Jenks, G.F., 1967, The data model concept in statistical mapping: International Yearbook of Cartography, v. 7, p. 186-190.

Karl, T.R., Melillo, J.M., and Peterson, T.C., eds., 2009, Global climate change impacts in the United States: New York, Cambridge University Press, Information taken from http://downloads. globalchange.gov/usimpacts/pdfs/climate-impacts-report.pdf.

Kaushal, S.S., Likens, G.E., Jaworski, N.A., Pace, M.L., Sides, A.M., Seekell, D., Belt, K.T., Secor, D.H., and Wingate, R.L., 2010, Rising stream and river temperatures in the United States: Frontiers in Ecology and the Environment, doi:10.1890/090037, accessed March 23, 2010, at http://www.esajournals.org/doi/pdf/10.1890/090037.

Keleher, C.J., and Rahel, F.J., 1996, Thermal limits to salmonid distributions in the Rocky Mountain region and potential habitat loss due to global warming-A geographic information system (GIS) approach: Transactions of the American Fisheries Society, v. 125, no. 1, p. 1-13.

Kennedy, T.L., Gutzler, D.S., and Leung, R.L., 2008, Predicting future threats to the long-term survival of Gila trout using a high-resolution simulation of climate change: Climatic Change, v. 94, no. 3-4, p. 503-515. 
Kruse, C.G., Hubert, W.A., and Rahel, F.J., 2001, An assessment of headwater isolation as a conservation strategy for cutthroat trout in the Absaroka Mountains of Wyoming: Northwest Science, v. 75 , p. $1-11$.

Lesica, P., and Allendorf, F.W., 1995, When are peripheral populations valuable for conservation?: Conservation Biology, v. 9, p. 753-760.

Luce, C.H., and Holden, Z.A., 2009, Declining annual streamflow distributions in the Pacific Northwest United States, 1948-2006: Geophysical Research Letters, v. 36, citation number L16401, doi:10.1029/2009GL039407, accessed August 22, 2009, at http://www.agu.org/journals/gl/gl0916/ 2009GL039407/.

May, B.E., and Albeke, S., 2005, Range-wide status of Bonneville cutthroat trout (Oncorhynchus clarki utah)_2004: Salt Lake City, Utah, Utah Division of Wildlife Resources Publication Number 05-02, $67 \mathrm{p}$.

May, B.E., Albeke, S.E., and Horton, T., 2007, Range-wide status assessment for Yellowstone cutthroat trout (Oncorhynchus clarkii bouvieri)—2006: Helena, Mont., Yellowstone Cutthroat Trout Interagency Coordination Group, $81 \mathrm{p}$.

May, C.L., and Gresswell, R.E., 2003, Processes and rates of sediment and wood accumulation in headwater streams of the central Oregon Coast Range: Earth Surface Processes and Landforms, v. 28, p. 409-424.

McCabe, G.J., and Dettinger, M.D., 2002, Primary modes and predictability of year-to-year snowpack variations in the western United States from teleconnections with Pacific Ocean climate: Journal of Hydrometeorology, v. 3, p. 13-24.

McCabe, G.J., Palecki, M.A., and Betancourt, J.L., 2004, Pacific and Atlantic Ocean influences on multidecadal drought frequency in the United States: Proceedings of the National Academy of Sciences, v. 101, p. 4136-4141.

McCullough, D.A., Bartholow, J.M., Jager, H.I., Beschta, R.L., Cheslak, E.F., Deas, M.L., Ebersole, J.L., Foott, J.S., Johnson, S.L., Marine, K.R., Mesa, M.G., Petersen, J.H., Souchon, Y., Tiffan, K.F., and Wurtsbaugh, W.A., 2009, Research in thermal biology-Burning questions for coldwater stream fishes: Reviews in Fisheries Science, v. 17, p. 1, 90-115.

McHugh, P., and Budy, P., 2005, An experimental evaluation of competitive and thermal effects on brown trout (Salmo trutta) and Bonneville cutthroat trout (Oncorhynchus clarkii utah) performance along an altitudinal gradient: Canadian Journal of Fisheries and Aquatic Sciences, v. 62, p. 2784-2795.

McKenzie, D., Gedalof, Z., Peterson, D.L., and Mote, P., 2004, Climatic change, wildfire, and conservation: Conservation Biology, v. 18, p. 890-902.

McPhail, J.D., and Lindsey, C.C., 1986, Zoogeography of the freshwater fishes of Cascadia (the Columbia system and rivers north to the Stikine), in Hocutt, C.H., and Wiley, E.O., eds., The zoogeography of North American freshwater fishes: New York, John Wiley and Sons, p. 615-637.

Milner, A.M., Knudsen, E.E., Soiseth, C., Robertson, A.L., Schell, D., Phillips, I.T., and Magnusson, K., 2000, Colonization and development of stream communities across a 200-year gradient in Glacier Bay National Park, Alaska, USA: Canadian Journal of Fisheries and Aquatic Sciences, v. 57, p. 2319-2335. 


\section{$72 \mid$ References}

Mote, P., Salathe, E., Duliere, V., and Jump, E., 2008, Scenarios of future climate for the Pacific Northwest: Seattle, Wash., University of Washington, Information taken from http://cses.washington. edu/db/pdf/moteetal2008scenarios628.pdf.

Morrison, J., Quick, M.C., and Foreman, M.G.C., 2002, Climate change in the Fraser River watershed-Flow and temperature projections: Journal of Hydrology, v. 263, p. 230-244.

Nakano, S., Kitano, F., and Maekawa, K., 1996, Potential fragmentation and loss of thermal habitats for charrs in the Japanese archipelago due to climate warming: Freshwater Biology, v. 36, p. 711-722.

Neville, H.M., Dunham, J.B., and Peacock, M.M., 2006, Landscape attributes and life history variability shape genetic structure of trout populations in a stream network: Landscape Ecology, v. 21, p. 901-916.

Nielsen, J.L., Scott, J.M., and Aycrigg, J.L., 2001, Endangered species and peripheral populationsCause for conservation: Endangered Species Update, v. 18, p. 194-197.

Pagano, T., and Garen, D., 2005, A recent increase in western U.S. streamflow variability and persistence: Journal of Hydrometeorology, v. 6, p. 173-179.

Petersen, J.H., and Kitchell, J.F., 2001, Climate regimes and water temperature changes in the Columbia River-Bioenergetic implications for predators of juvenile salmon: Canadian Journal of Fisheries and Aquatic Sciences, v. 58, p. 1831-1841.

Pittock, A.B., 2006, Are scientists underestimating climate change?: Eos, Transactions, American Geophysical Union, v. 87, p. 340-341.

Rahel, F.J., Keleher, C.J., and Anderson, J.L., 1996, Potential habitat loss and population fragmentation for cold water fish in the North Platte River drainage of the Rocky Mountains-Response to climate warming: Limnology and Oceanography, v. 41, p. 1116-1123.

Rahel, F.J., and Olden, J.D., 2008, Assessing the effects of climate change on invasive species: Conservation Biology, v. 22, p. 521-533.

Raupach, M.R., Marland, G., Ciais, P., Le Quéré, C., Canadell, J.G., Klepper, G., and Field, C.B., 2007, Global and regional drivers of accelerating $\mathrm{CO}_{2}$ emissions: Proceedings of the National Academy of Sciences, v. 104, p. 10288-10293.

Rieman, B.E., and Dunham, J.B., 2000, Metapopulations and salmonids-A synthesis of life history patterns and empirical observations: Ecology of Freshwater Fish, v. 9, p. 51-64.

Rieman, B.E., Isaak, D., Adams, S., Horan, D., Nagel, D., Luce, C., and Myers, D., 2007, Spatial variation in anticipated climate change effects on bull trout habitats across the interior Columbia River basin: Transactions of the American Fisheries Society, v. 136, p. 1552-1565.

Rieman, B., Lee, D., Burns, D., Gresswell, R., Young, M., Stowell, R., Rinne, J., and Howell, P., 2003, Status of native fishes in the western United States and issues for fire and fuels management: Forest Ecology and Management, v. 178, p. 197-211.

Rieman, B.E., Peterson, J.T., and Myers, D.L., 2006, Have brook trout displaced bull trout along longitudinal gradients in central Idaho streams?: Canadian Journal of Fisheries and Aquatic Sciences, v. 63, p. 63-78.

Rinne, J.N., 1996, Short-term effects of wildfire on fishes and aquatic macroinvertebrates in the southwestern United States: North American Journal of Fisheries Management, v. 16, p. 653-658. 
Rinne, J.N., and Minckley, W.L., 1985, Patterns of variation and distribution in Apache trout (Salmo apache) relative to co-occurrence with introduced salmonids: Copeia, v. 2, p. 285-292.

Rood, S.B., Pan, J., Gill, K.M., Franks, C.G., Samuelson, G.M., and Shepherd, A., 2008, Declining summer flows of Rocky Mountain rivers-Changing seasonal hydrology and probable impacts on floodplain forests: Journal of Hydrology, v. 349, p. 397-410.

Saunders, S., Montgomery, C., Easley, T., and Spencer, T., 2008, Hotter and drier-The West's changed climate: The Rocky Mountain Climate Organization, accessed June 24, 2009, at http://www.rockymountainclimate.org/website\%20pictures/Hotter\%20and\%20Drier.pdf.

Scudder, G.G.E., 1989, The adaptive significance of marginal populations-A general perspective, in Levings, C.D., Holtby, L.B., and Henderson, M.A., eds., Proceedings of the national workshop on effects of habitat alteration on salmonid stocks: Canadian Special Publication Fisheries and Aquatic Sciences 105, p. 180-185.

Selong, J.H., McMahon, T.E., Zale, A.V., and Barrows, F.T., 2001, Effect of temperature on growth and survival of bull trout with application of an improved method for determining thermal tolerance in fishes: Transactions of the American Fisheries Society, v. 130, p. 1026-1037.

Shepard, B.B., May, B.E., and Urie, W., 2003, Status of westslope cutthroat trout (Oncorhynchus clarki lewisi) in the United States-2002: Westslope Cutthroat Trout Interagency Conservation Team, report to Montana Fish, Wildlife, and Parks.

Siegenthaler, U., Stocker, T.F., Monnin, E., Luthi, D., Schwander, J., Stauffer, B., Raynaud, D., Barnola, J., Fischer, H., Masson-Delmotte, V., Jouzel, J., 2005, Stable carbon cycle-climate relationship during the late Pleistocene: Science, v. 310, p. 1313-1317.

Stewart, I.T., Cayan, D.R., and Dettinger, M.D., 2005, Changes toward earlier streamflow timing across western North American: Journal of Climate, v. 18, p. 1136-1155.

Thurow, R.F., Lee, D.C., and Rieman, B.E., 1997, Distribution and status of seven native salmonids in the interior Columbia River basin and portions of the Klamath River and Great Basins: North American Journal of Fisheries Management, v. 17, p. 1094-1110.

Todd, A.S., Coleman, M.A., Konowal, A.M., May, M.K., Johnson, S., Vieira, N.K.M., and Saunders, J.F., 2008, Development of new water temperature criteria to protect Colorado's fisheries: Fisheries, v. 33, no. 9, p. 433-443.

Trotter, P., 2008, Cutthroat-Native trout of the west: Berkeley, Calif., University of California Press, $547 \mathrm{p}$.

van Mantgem, P.J., and Stephenson, N.L., 2007, Apparent climatically induced increase of tree mortality rates in a temperate forest: Ecology Letters, v. 10, p. 909-916.

Waples, R.S., Pess, G.R., and Beechie, T., 2008, Evolutionary history of Pacific salmon in dynamic environments: Evolutionary Applications, v. 1, p. 189-206.

Wehrly, K.E., Wang, L., and Mitro, M., 2007, Field-based estimates of thermal tolerance limits for trout-Incorporating exposure time and temperature fluctuation: Transactions of the American Fisheries Society, v. 136, p. 365-374.

Westerling, A.L., Hidalgo, H.G., Cayan, D.R., and Swetnam, T.W., 2006, Warming and earlier spring increase-Western U.S. forest wildfire activity: Science, v. 313, p. 940-943. 


\section{$74 \mid$ References}

Williams, J.E., Haak, A.L., Neville, H.M., and Colyer, W.T., 2009, Potential consequences of climate change to persistence of cutthroat trout populations: North American Journal of Fisheries Management, v. 29, p, 533-548.

Young, M.K., 1995, Conservation assessment for inland cutthroat trout: U.S. Forest Service, Rocky Mountain Forest and Range Experiment Station, General Technical Report RM-GTR-256, 61 p.

Publishing support provided by:

Denver Publishing Service Center

For more information concerning this publication, contact:

Center Director, USGS Northern Rocky Mountain Science Center

2327 University Way, Suite 2

Bozeman, MT59715

(406) $994-4293$

Or visit the Northern Rocky Mountain Science Center Web site at:

http://www.nrmsc.usgs.gov/ 



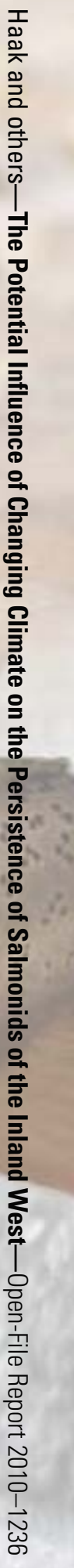

19 Printed on recycled paper 